\title{
Historical Phenology of West Virginia: 130 Years of Spring Avian Migration and Wildflower Blooming
}

Lori M. Petrauski

Follow this and additional works at: https://researchrepository.wvu.edu/etd

\section{Recommended Citation}

Petrauski, Lori M., "Historical Phenology of West Virginia: 130 Years of Spring Avian Migration and Wildflower Blooming" (2017). Graduate Theses, Dissertations, and Problem Reports. 6413.

https://researchrepository.wvu.edu/etd/6413

This Thesis is protected by copyright and/or related rights. It has been brought to you by the The Research Repository @ WVU with permission from the rights-holder(s). You are free to use this Thesis in any way that is permitted by the copyright and related rights legislation that applies to your use. For other uses you must obtain permission from the rights-holder(s) directly, unless additional rights are indicated by a Creative Commons license in the record and/ or on the work itself. This Thesis has been accepted for inclusion in WVU Graduate Theses, Dissertations, and Problem Reports collection by an authorized administrator of The Research Repository @ WVU. For more information, please contact researchrepository@mail.wvu.edu. 
Historical Phenology of West Virginia: 130 Years of Spring Avian Migration and Wildflower Blooming

\title{
Lori M. Petrauski
}

\begin{abstract}
Thesis submitted to the Davis College of Agriculture, Natural Resources and Design at West Virginia University in partial fulfillment of the requirements for the degree of

Master of Science in

Wildlife and Fisheries Resources
\end{abstract}

James T. Anderson, Ph.D., Chair

Sheldon Owen, Ph.D.

George Constantz, Ph.D.

School of Natural Resources

Morgantown, West Virginia

2017

Keywords: Phenology, Historical Data, Climate Change, Avian Migration, Wildflower Blooming

Copyright 2017 Lori Petrauski 


\begin{abstract}
Historical Phenology of West Virginia: 130 Years of Spring Avian Migration and Wildflower Blooming

Lori Petrauski

Phenology, or the study of biological cycles in relation to the seasons, is a useful approach to study climate change and its effects on species. Analyzing historical records of phenology can give clues to understanding the future of ecosystems in relation to climate change. Specifically, using untapped sources of historical phenological data such as museum specimens, journals written by nature-minded citizens, and dated photographs can expand our temporal range of phenology data and provide a baseline with which to compare current phenology observations.
\end{abstract}

There is no central database for historical phenology data in West Virginia and there has been little research about the phenology of plants and animals in the state. The primary research objective of this study was to determine if phenophases of plants and animals have advanced in timing in West Virginia using historical sources. This question was addressed by creation of the West Virginia Climate History Project, which began in January 2015, with the goal to gather phenological information from archival sources in West Virginia, which resulted in scientifically and culturally relevant conclusions. This information was used to analyze patterns of avian spring migration and wildflower blooming over the last 130 years.

The average avian migrant has advanced its spring arrival by 1.7 days per decade over the last 127 years. Arrival dates were associated with increasing spring temperatures - for each $1{ }^{\circ} \mathrm{C}$ increase in spring temperature, arrival date advanced by 0.81 days/decade. Several life history traits were linked to species that advanced their first arrival dates, including a shorter distance migrated to reach wintering grounds, increasing populations, and foraging habitat.

Two common spring ephemeral wildflowers, Cutleaf Toothwort (Cardamine concatenata) and Yellow Trout Lily (Erythronium americanum), have advanced their spring blooming in West Virginia over the last 125 years $(\bar{x}=1.01$ days/decade). Spring temperature was the strongest predictor of blooming date (2.91 and 3.57 days earlier $/ 1^{\circ} \mathrm{C}$ increase in spring temperature, respectively). Flowers at $<500 \mathrm{~m}$ elevation bloomed earlier and demonstrated a stronger shift in flowering date over time than flowers at $>1000 \mathrm{~m}$ elevations.

This study demonstrates the plasticity of responses of some avian and wildflower species and highlights several factors that could lead to increased risk to other species due to climate change. These studies have also demonstrated the usefulness of archival sources to phenological and climate change studies, even over a large, variable geographic area. 


\section{ACKNOWLEDGMENTS}

Thanks to the West Virginia University Natural History Museum, West Virginia Humanities Council, and the U.S. Department of Agriculture Northeast Climate Hub for providing funding for this project. I thank Dr. Anderson for his patience, support, and guidance. I thank my committee members, Dr. Owen and Dr. Constantz for their thoughtful reviews. Thanks to members of the Brooks Bird Club who helped me think critically about the flora and fauna of West Virginia. I thank the many people who contributed observations and access to data, including the Brooks Bird Club, Mike Breiding, the West Virginia Regional History Center, eBird, Carnegie Museum of Natural History, West Virginia University Herbarium, Fairmont State University Herbarium, University of Charleston Herbarium, George B. Rossbach Herbarium, Marshall University Herbarium, David Smaldone (Recreation, Parks, and Tourism Resources, West Virginia University), and Andrew Walker (Potomac State University). Thanks to Greg Good (American Institute of Physics) and Thomas Rodd (Friends of Blackwater) for ideas and logistics. Thanks to everyone who assisted me in transcribing records, including Jen DeSimone and Kasey Osborne. A special thanks to Nick Goodman and my family for their positivity and encouragement, and for supporting me in countless ways. 


\section{TABLE OF CONTENTS}

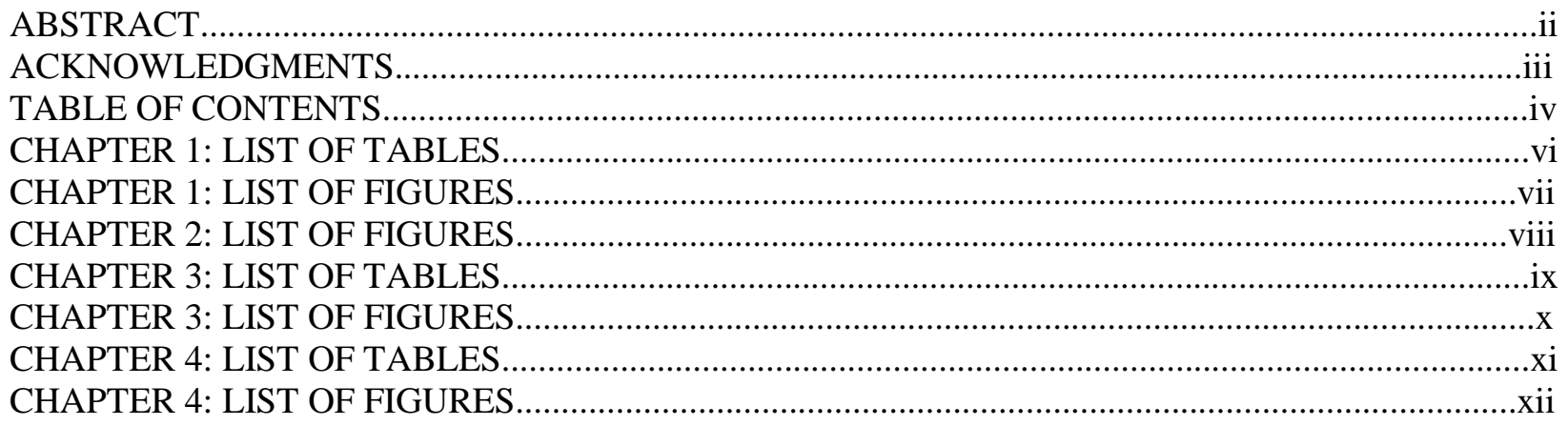

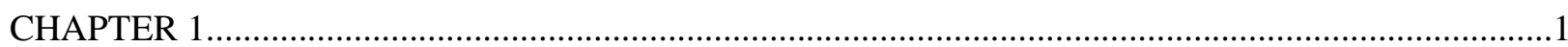

Introduction to the West Virginia Climate History Project.............................................................

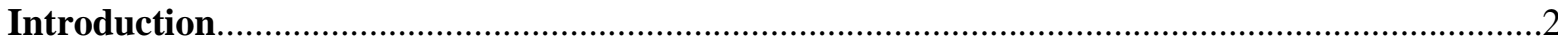

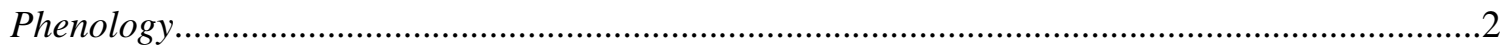

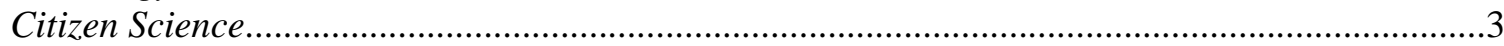

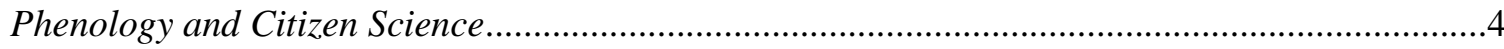

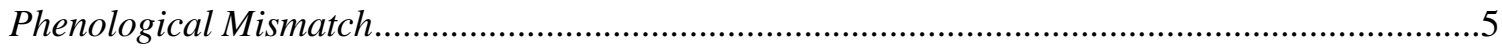

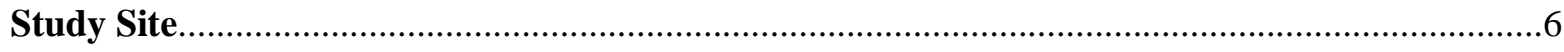

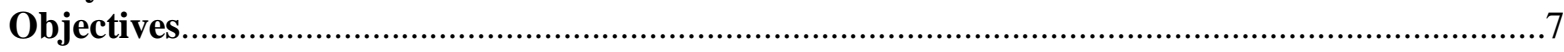

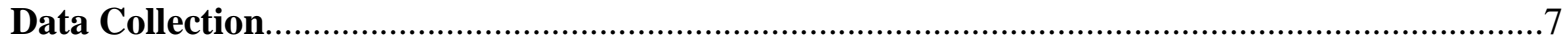

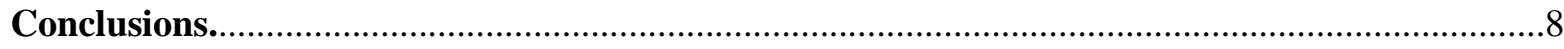

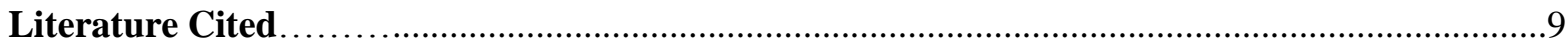

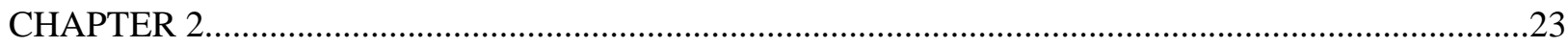

Developing a Historical Phenology Dataset Through Community Involvement for Climate Change

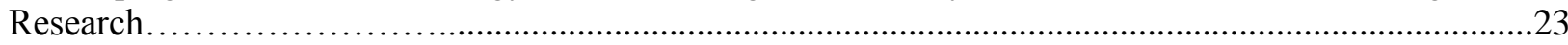

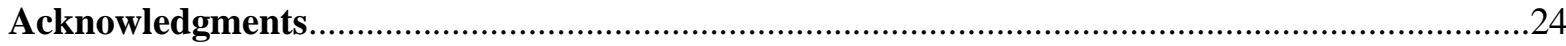

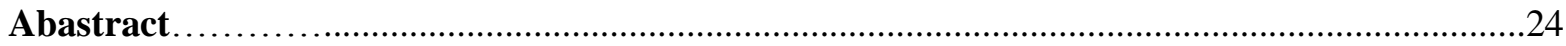

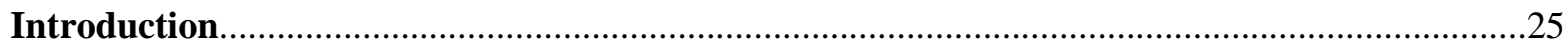

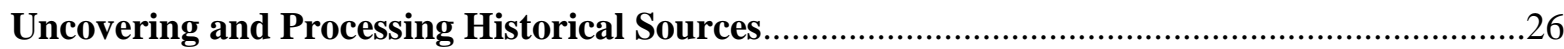

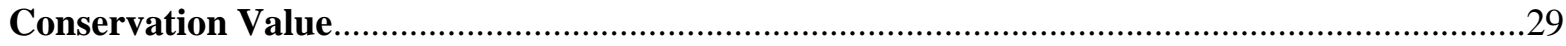

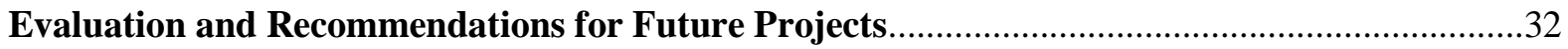

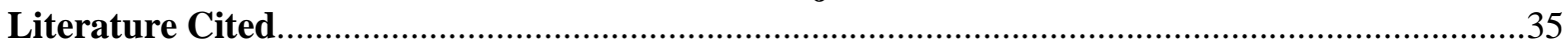

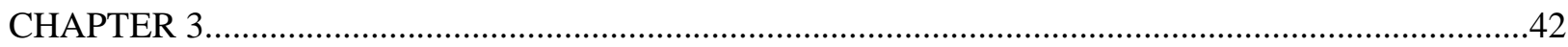

Changes in Flowering Phenology Over 125 Years in the Central Appalachians...................................42

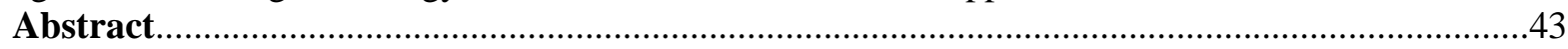

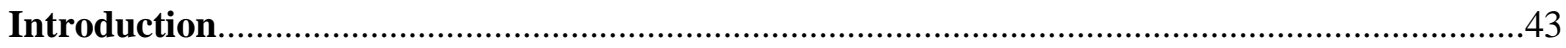

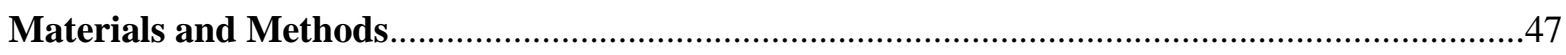

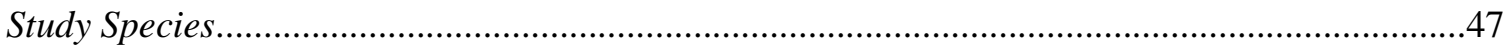

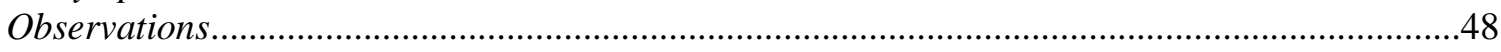

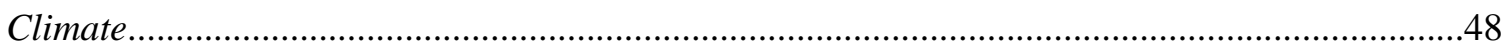

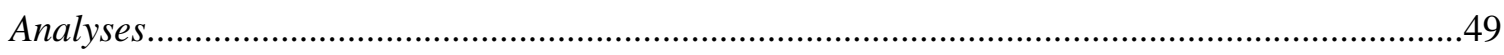

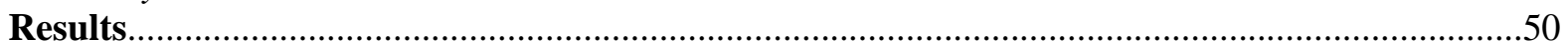




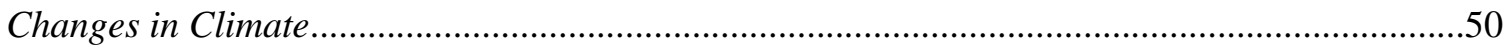

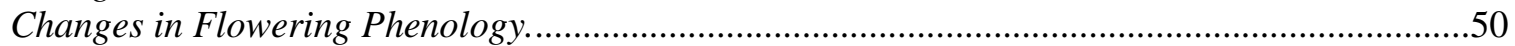

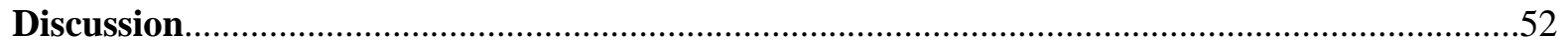

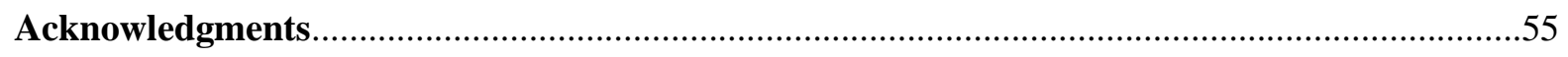

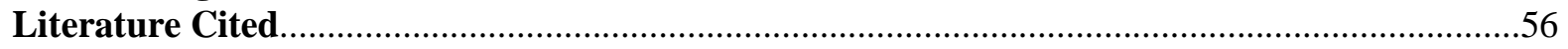

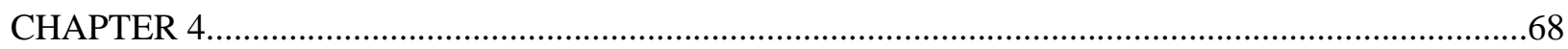

Changes in Avian Spring Arrival Dates of 115 Species in the Central Appalachians over 127 Years.......68

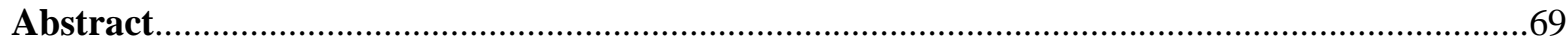

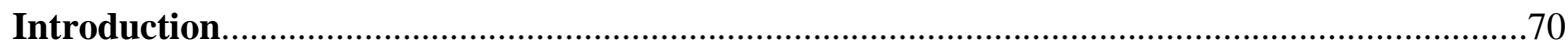

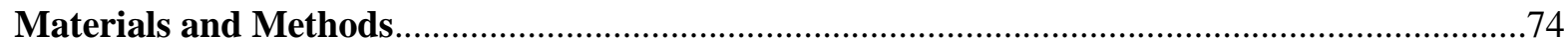

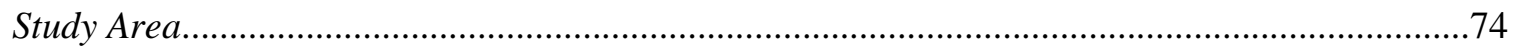

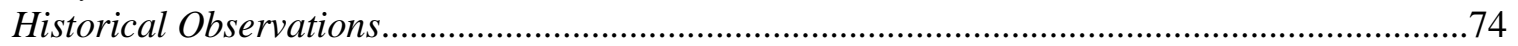

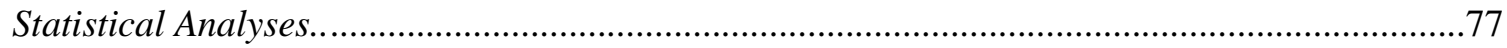

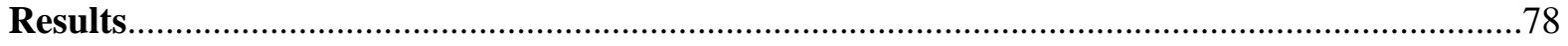

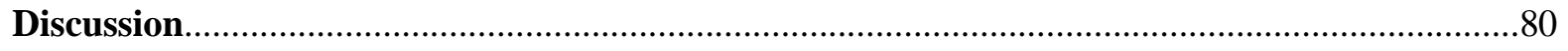

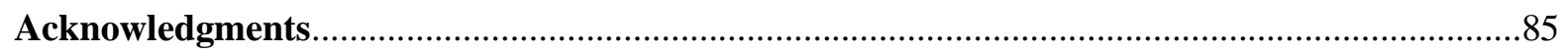

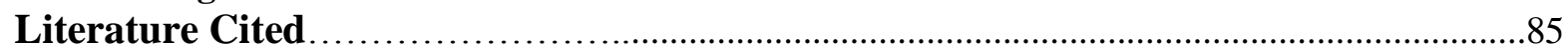


Chapter 1: List of Tables

Table 1. List of outreach methods used to find sources of data for the West Virginia Climate History

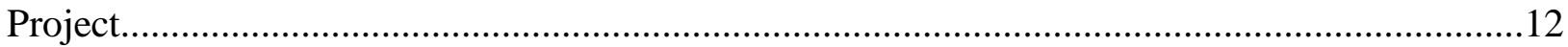

Table 2. Phenophases and number of phenology observation found with the West Virginia Climate History

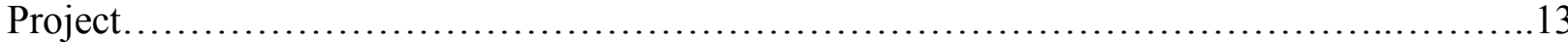


Chapter 1: List of Figures

Figure 1. Outreach flyer sent to public libraries and people with potential phenology data in West

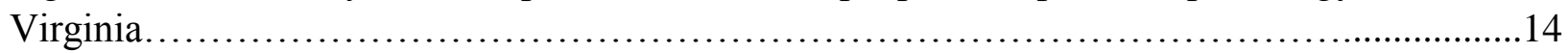

Figure 2. Excerpt from a personal journal from Hardy County, West Virginia in May 1973 that

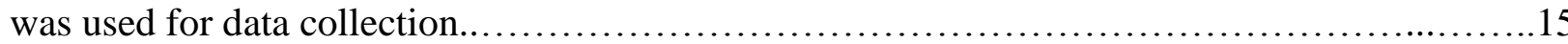

Figure 3. Example of a herbarium specimen used for data collection. This is a pressed Cutleaf Toothwort from Monongahela County, West Virginia in 1942 from the Carnegie Museum of Natural History in Pittsburgh, Pennsylvania....

Figure 4. The front page of The Redstart from 1937, the official publication of the Brooks Bird Club, which was used for data collection............................................. 17

Figure 5. Map of observations of the Passenger Pigeon Ectopistes migratorius made by Earl Brooks between 1890 and 1915, which is housed in the West Virginia Regional History Center in Morgantown, West Virginia

Figure 6. Personal photograph of Yellow Trout Lily Erythronium americanum and Virginia Bluebells Mertensia virginica in the Core Arboretum, Morgantown, West Virginia on April 14, 2014 by David Smaldone. Dated photographs such as this were used in data collection

Figure 7. Typed bird list collected by George Brieding of Wheeling, West Virginia in 1955.

Figure 8. Photograph of Cutleaf Toothwort Cardamine concatenata by David Smaldone.

Figure 9. Photo of Yellow Trout Lily Erythronium americanum by David Smaldone. 
Chapter 2: List of Tables

Table 1. Sources of data used in the West Virginia Climate History Project. WV refers to West

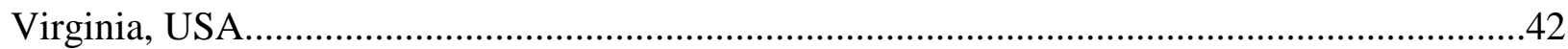


Chapter 3: List of Tables

Table 1. Sources of flowering data for Cardamine concatenata and Erythronium americanum in West Virginia, USA over the last 125 years. .........................................63 


\section{Chapter 3: List of Figures}

Figure 1. Average climate in West Virginia, USA over 125 years (1890-2014). (A) Spring temperature is average March-April temperatures, (B) spring precipitation is average MarchApril rainfall, and (C) winter temperature is average January - February temperature based on 13 United States Historical Climatology Network recording stations located in West

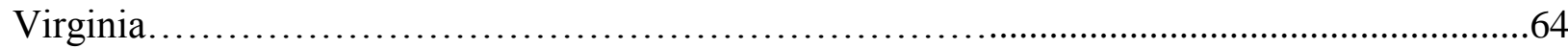

Figure 2. Spring temperature (March - April) interpolations in West Virginia, USA from the 1890s (1890-1899) and 2000s (2000-2014). Interpolations are based on climate data from 13 United States Historical Climatology Network recording stations located in West Virginia.

Figure 3. Winter temperature (January - February) interpolations in West Virginia, USA from the 1890s (1890-1899) and 2000s (2000-2014). Interpolations are based on climate data from 13 United States Historical Climatology Network recording stations located in West Virginia.

Figure 4. Spring precipitation (March - April) interpolations in West Virginia, USA from the 1890s (1890-1899) and 2000s (2000-2014). Interpolations are based on climate data from 13 United States Historical Climatology Network recording stations West

Virginia....

Figure 5. Flowering dates of (A) C. concatenata and (B) E. americanum in West Virginia, USA from 1890-2015 .68 
Chapter 4: List of Tables

Table 1. Sources used to find historical first arrival dates of migrating bird species [in West

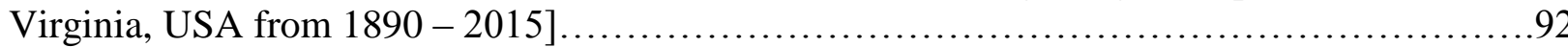

Table 2. Species that demonstrated significant trends towards earlier first arrival dates (FADs) in West Virginia. USA. Foraging habitat is denoted by $\mathrm{f}$ (forest), w (wetland), a (aerial), s (scrub), and $g$ (grassland). Population status is denoted by + (increasing), - (decreasing), and = (steady). Distance is categorized either by short-distance migrants (wintering north of the Caribbean) or long-distance migrants (wintering south of the Caribbean). Historical FAD is the average arrival date before 1970 and current FAD is the average arrival date of 1970 or after.................94

Table 3. Species that demonstrated non-significant, later trends in first arrival dates (FADs) in West Virginia, USA. Foraging habitat is denoted by $\mathrm{f}$ (forest), w (wetland), a (aerial), s (scrub), and $g$ (grassland). Population status is denoted by + (increasing), - (decreasing), and = (steady). Distance is categorized either by short-distance migrants (wintering north of the Caribbean) or long-distance migrants (wintering south of the Caribbean). Historical FAD is the average arrival date before 1970 and current FAD is the average arrival date of 1970 or after...............97

Table 4. Species that demonstrated non-significant, but earlier trends in first arrival dates (FADs) in West Virginia, USA. Foraging habitat is denoted by $\mathrm{f}$ (forest), w (wetland), a (aerial), $\mathrm{s}$ (scrub), and g (grassland). Population status is denoted by + (increasing), - (decreasing), and = (steady). Distance is categorized either by short-distance migrants (wintering north of the Caribbean) or long-distance migrants (wintering south of the Caribbean). Historical FAD is the average arrival date before 1970 and current FAD is the average arrival date of 1970 or after. Species that are bold would be significant if no Bonferroni corrections were used.

Table 5. Bonferroni corrections were made to the alpha values (0.05) based on number of species within an Order................................................................. 102 
Chapter 4: List of Figures

Figure 1. Map of West Virginia counties and climate recording stations of the United States Historical Climate Network...................................................93

Figure 2. The average yearly first arrival date across 115 species in West Virginia (1889-

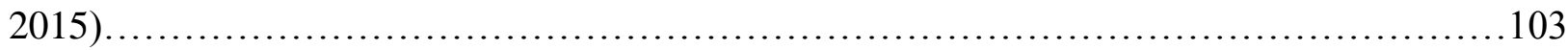

Figure 3. Mean March-April temperatures in West Virginia (1890 - 2014). Data recorded by the United States Historical Climate Network.............................................104 


\title{
CHAPTER 1
}

\section{Introduction to the West Virginia Climate History Project}

\author{
Lori Petrauski ${ }^{1}$
}

${ }^{1}$ School of Natural Resources, Wildlife and Fisheries Resources Program, West Virginia University, PO Box 6125, Percival Hall, Morgantown, WV 26506 


\section{Introduction}

The West Virginia Climate History Project began in January 2015, with a goal to gather phenological information from archival sources in West Virginia. This information was used to analyze patterns of avian spring migration and wildflower blooming over the last 130 years. The data gathered through this project can be used and built upon to create citizen science projects and conduct future research about the phenology of West Virginia.

\section{Phenology}

Phenology is the study of the cycle of biological events, called phenophases, throughout the year. Plants and animals exhibit seasonal patterns in their behavior because there is a distinct seasonality to when their environment is favorable enough to grow and reproduce (Visser \& Both 2005). Therefore, species' life-cycle events are sensitive to climatological changes - such as flowering, leaf-out, migration, insect emergence, and breeding (Denny et al. 2014). These responses can alter species' abundance, distribution, productivity, reproduction, and survival (Fabina et al., 2010; Enquist et al., 2014). Studying phenology or changes in phenology can give clues to understanding the future of ecosystems in relation to climate change.

Studying phenology has become substantially popular in the last decade due to its public accessibility (Lawrence 2009), potential for scientific education (Bonney et al. 2009), and usefulness in tracking responses to climate change (Visser \& Both 2005). With the rise of current phenology datasets, there is a need to uncover historic phenology data, so researchers can track changes over time. There has been a surge in attempts by researchers to utilize untapped sources of historical phenological data such as museum specimens, journals written by nature-minded citizens, and dated photographs (Miller-Rushing et al. 2006; Ellwood et al. 2010; Primack \& Miller-Rushing 2012). 
Historical phenological observations have been used to create baseline datasets for bird migration (Zelt et al. 2012; Travers et al. 2015), first flowering dates (Miller-Rushing et al. 2008; Abu-Asab et al. 2001), and leaf-out dates (Everill et al. 2014; Polgar \& Primack 2011). Researchers have used phenological data found in journals from naturalist-minded authors as a baseline to compare current and historic dates of phenological events to estimate how climate change affected the timing of phenophases (Bradley et al. 1999; Polgar \& Primack 2011). These isolated studies are important for understanding individual organisms' responses to changes in climate and for involving local communities with research about familiar flora and fauna.

\section{Citizen science}

Citizen science is the involvement of citizens in the scientific process. This can include a citizen role in data collection, hypothesis formation, analysis, or all three. There are conflicting definitions within the literature, including terms defined by the Federal Community of Practice for Crowdsourcing and Citizen Science, which separates crowdsourcing and citizen science as two separate entities based on the idea that citizen science requires open collaboration between the public and scientists (Balcom 2015). It has been argued that projects that have no two-way communication between scientists and non-professionals can still be defined as citizen science, and that the public's participation in the research can be based on natural history observations that were never hypothesis-driven (Miller-Rushing et al. 2012). To deal with these discrepancies the term public participation in scientific research (PPSR) has been offered as a replacement to citizen science (Bonney et al. 2009; Wiggins \& Crowston 2011; Shirk et al. 2012) due to the vague definitions of citizen science and the inclusivity of PPSR, which includes citizen science, monitoring projects, and crowdsourcing. Within PPSR, there are several categories of projects 
that depend on the degree of public participation (Bonney et al. 2009), including contributory, collaborative, and co-created projects.

The West Virginia Climate History Project is a contributory citizen-science project in which there is no interaction between the original citizen scientists and the professional scientists. Contributory projects only involve the public in data collection, and in this case, most of the data collectors are no longer living. The main outcomes of this project were scientific with potential to develop educational outcomes in the future.

\section{Phenology and Citizen Science}

Phenology is a popular tool used in contributory PPSR projects. Historical phenological observations are useful for creating baseline datasets with which to compare current phenology data. Zelt et al. (2012) developed a historical baseline dataset of bird arrival dates for two species using data collected from the North American Bird Phenology Program (BPP) between 1881 and 1970. The BPP was originally intended to study the migration patterns of birds, but was used to find changes in migration dates due to climate change. Researchers have used phenological data found in journals from naturalist-minded authors as a baseline to compare contemporary and early phenology (Bradley et al. 1999; Polgar \& Primack 2011).

Using observations collected by Henry David Thoreau, laboratory studies, and current observations, Polgar and Primack (2011) was able to compare current leaf-out timing and temperature sensitivity of trees to trees from the 1850s. Their studies indicated that trees leafed out an average of 18 days earlier than they did in Thoreau's notes. In the case of this research study, when comparing the native and invasive exotic tree species, they found that the invasive trees were less sensitive to temperature changes and could have more of a competitive advantage as temperatures increase. Bradley et al. (1999) used observations from Aldo Leopold's journals 
of phenophases (life cycle events) and determined about one-third of the phenophases reported by Leopold appeared to have advanced in earliness between 1936 and 1947. In these situations, historical observations from archival sources were used to compare current and old dates of phenological events to gage how climate change affected the timing of phenophases.

Currently, the overarching phenological databases attempt to synthesize data from individuals and smaller phenological monitoring projects, increase internetwork communication, and promote the practical use of phenological data (van Vliet et al. 2003) as well as increase public awareness of phenology, climate change, and the scientific process (Haggerty and Mazer 2008, Meymaris et al. 2008). However, the implementation of these databases is relatively recent (US-NPN was created in 2007) and establishing baseline data is still a challenge for phenological research (Betancourt et al. 2007, Weltzin 2011). Researchers have had to use creative methods in order to gather long-term baseline data-including the use of herbarium specimens, observations from diaries, and newspapers.

\section{Phenological Mismatch}

One of the major drivers of phenological studies is the possibility of phenological mismatch (Root et al., 2003), which can occur when species advance (Kudo and Ida, 2013) or delay (Gezon et al., 2016) their phenologies in relation to interacting species. The survival of a species depends as much on their ability to respond to changes in climate as it depends on their ability to respond to changes in their interacting species due to climate change (Fabina et al., 2010). For example, if herbivores become active before pollinators in the spring, the plants will be consumed before they are pollinated and the success of the plants and pollinators will decrease as a result of the herbivores' shifting phenology (Fabina et al., 2010). 
Given that phenological mismatches are one of the common drivers of phenological studies, exploring species interactions is an important step in understanding the future of these relationships. Species that demonstrate phenotypic plasticity are thought to be more prepared for future changes in climate (Elzinga et al., 2007).

\section{Study Site}

West Virginia is a heavily forested, mountainous state located in the Appalachian region of the United States. Temperature, elevation, and precipitation differ considerably throughout the state. The average statewide yearly temperature is $6-17(\mathrm{C})$, where the lower southern regions are warmer than the mountainous regions. The average elevation is $457 \mathrm{~m}$ with the highest point (Spruce Knob) at 1,482 m and the lowest point (Harper's Ferry) at $149 \mathrm{~m}$ above sea level. Annual precipitation ranges between 81 and $132 \mathrm{~cm}$ statewide. A majority of West Virginia is forested mostly with mixed hardwoods, and the Monongahela National Forest is partially composed of boreal forests and spruce trees. The rich biodiversity of West Virginia offers itself well to studying phenology.

Between 1970 and 2014, average spring temperatures (March-April) in West Virginia increased 10 times as much as they did between 1880 and 1970 . Over the 125 year study period, the average climate variables have mostly remained constant when analyzed over the entire state. Spring precipitation, spring temperature, and winter temperature have only increased slightly (precipitation increasing $0.030 \mathrm{~cm} /$ decade; spring temperature increasing $0.055^{\circ} \mathrm{C} / \mathrm{decade}$; winter temperature increasing $0.003^{\circ} \mathrm{C} /$ decade) since 1890 . However, variation in temperature and precipitation exists within West Virginia and change over time is evident in some parts of the state more than others. 


\section{Objectives}

Phenology is a useful approach in studying climate change and its effects on species. There is no central database for historical phenology data in West Virginia and there has been little research about the phenology of plants and animals in the state. The primary research objective of this study was to determine if phenophases of plants and animals have advanced in timing in West Virginia using historical sources. This question was addressed with the following objectives:

1) To create a baseline phenological dataset for West Virginia.

2) To determine if there have been changes in timing of first arrival in bird species due to climatic factors in West Virginia.

3) To determine if there has been a change in spring flowering over time depending on elevation and climate in West Virginia.

\section{Data Collection}

The project began with public outreach (Table 1), including presentations with local naturalist groups, informational fliers sent to public libraries (Figure 1), a press release through the university, an online project blog (http://wvphenology.wordpress.com), and a West Virginia National Public Radio interview. A variety of historical data were used during this project, including personal journals (Figure 2), herbarium specimens (Figure 3), naturalist group newsletters (Figure 4), records from history centers (Figure 5), personal photographs (Figure 6), and typed bird lists (Figure 7) from West Virginians. Transcribing data from handwritten notes, journals, and lists ( $24 \%$ of the data, $n=1350$ observations) required patience and investigative 
skills; whereas data that were printed in newsletters, lists, or herbarium-labels were transcribed with less effort.

Overall, the WVCHP collected 7,181 historical phenology observations covering 24 phenophases (Table 2) and 404 different species, including 258 species of birds, 37 species of trees and shrubs, 100 species of herbs and forbs, 2 insect species, 1 mammal, 3 amphibian species, and 3 grasses. Most of the observations (80.2\%) were used in analysis of avian spring migration and wildflower blooming for publications. Specifically, blooming data of Cutleaf Toothwort Cardamine concatinata (Figure 8) and Yellow Trout Lily Erythronium americanum (Figure 9) were used to determine temporal changes of blooming. The other 19.8\% of the data covered a range of species and phenophases that we were unable to analyze due to an insufficient number of consistent observations.

\section{Conclusions}

Overall, these studies demonstrate the plasticity of responses of some avian and wildflower species and highlights several factors that could lead to increased risk to other species due to climate change. These studies have also demonstrated the usefulness of archival sources to phenological and climate change studies, even over a large, variable geographic area.

\section{Acknowledgments}

There were many people involved with this project. There were 242 people who were directly involved with data collection for this project over the last 130 years. This number does not include the many individuals who were associated with naturalist groups and clubs that also collected data, including the Herb/Forb Club in Oglebay, the Brooks Bird Club, National Park Service, and the West Virginia University Department of Biology. This number also does not include the people I worked with to access the data, including herbarium curators, history center staff, and the audiences of my presentations about the project. 


\section{Literature Cited}

Abu-Asab, M., P. Peterson, S. Shetler, and S. Orli. 2001. Earlier plant flowering in spring as a response to global warming in the Washington, DC, area. Biodiversity \& Conservation 10: 597-612.

Balcom, B. 2015. Improving Crowdsourcing and Citizen Science as a Policy Mechanism for NASA. New Space 3: 98-116.

Betancourt, J.L., Schwartz, M.D., Breshears, D.D., Brewer, C.A., Frazer, G., Gross, J.E., Mazer, S.J., Reed, B.C. and Wilson, B.E. 2007. Evolving plans for the USA National Phenology Network. Eos, Transactions American Geophysical Union 88: 211-211.

Bradley, N.L., et al. 1999. Phenological changes reflect climate change in Wisconsin. Proceedings of the National Academy of Sciences 96: 9701-9704.

Bonney, R., Ballard, H., Jordan, R., McCallie, E., Phillips, T., Shirk, J., and Wilderman, C. C. 2009. Public Participation in Scientific Research: Defining the Field and Assessing Its Potential for Informal Science Education. A CAISE Inquiry Group Report. Online Submission.

Denny, E.G., et al. 2014. Standardized phenology monitoring methods to track plant and animal activity for science and resource management applications. International journal of biometeorology 58: 591-601.

Ellwood, E.R., Primack, R.B., and Talmadge, M.L. 2010. Effects of climate change on spring arrival times of birds in Thoreau's Concord from 1851 to 2007. The Condor 112: 754762.

Elzinga, J. A., Atlan, A., Biere, A., Gigord, L., Weis, A. E., and Bernasconi, G. 2007. Time after time: flowering phenology and biotic interactions. Trends in Ecology \& Evolution 22: $432-439$.

Enquist, C.A.F., et al. 2014. Phenology research for natural resource management in the United States. International Journal of Biometeorology 58: 579-589.

Everill, P.H., et al. 2014. Determining past leaf-out times of New England's deciduous forests from herbarium specimens. American Journal of Botany 101: 1293-1300. 
Fabina, N. S., Abbott, K. C., and Gilman, R. T. 2010. Sensitivity of plant-pollinator-herbivore communities to changes in phenology. Ecological Modelling 221: 453-458.

Gezon, Z., D. Inouye, and R. Irwin. 2016. Phenological change in a spring ephemeral: implications for pollination and plant reproduction. Global Change Biology 22: 17791793.

Haggerty, B., and S. Mazer. 2008. The phenology handbook: a guide to phenological monitoring for students, teachers, families, and nature enthusiasts. UCSB Phenology Stewardship Program. University of California, Santa Barbara, California, USA.

Kudo, G., and T. Ida. 2013. Early onset of spring increases the phenological mismatch between plants and pollinators. Ecology 94: 2311-2320.

Lawrence A. 2009. The first cuckoo in winter: phenology, recording, credibility and meaning in Britain. Global Environmental Change 19: 173-179.

Meymaris, K., Henderson, S., Alaback, P., \& Havens, K. 2008. Project budburst: Citizen science for all seasons. In AGU Fall Meeting Abstracts 1: 614.

Miller-Rushing, A.J., et al. 2006. Photographs and herbarium specimens as tools to document phenological changes in response to global warming. American Journal of Botany 93: $1667-1674$.

Miller-Rushing, A. J., Inouye, D. W., and Primack, R. B. 2008. How well do first flowering dates measure plant responses to climate change? The effects of population size and sampling frequency. Journal of Ecology 96: 1289-1296.

Miller-Rushing, A., Primack, R., and Bonney, R. 2012. The history of public participation in ecological research. Frontiers in Ecology and the Environment 10: 285-290

Polgar, C.A., and R.B. Primack. 2011. Leaf-out phenology of temperate woody plants: from trees to ecosystems. New Phytologist 191: 926-941.

Primack, R.B., and A.J. Miller-Rushing. 2012 Uncovering, collecting, and analyzing records to investigate the ecological impacts of climate change: a template from Thoreau's Concord. BioScience 62: 170-181. 
Root, T. L., Price, J. T., Hall, K. R., Schneider, S. H., Rosenzweig, C., and Pounds, J. A. 2003. Fingerprints of global warming on wild animals and plants. Nature 421: 57-60.

Shirk, J., Ballard, H., Wilderman, C., Phillips, T., Wiggins, A., Jordan, R., McCallie, E., Minarchek, M., Lewenstein, B., Krasny, M. and Bonney, R., 2012. Public participation in scientific research: a framework for deliberate design. Ecology and Society 17: 2-8.

Travers, S.E., Marquardt, B., Zerr, N.J., Finch, J.B., Boche, M.J., Wilk, R., Burdick, S.C. 2015. Climate change and shifting arrival date of migratory birds over a century in the northern Great Plains. The Wilson Journal of Ornithology 127: 43-51.

Visser, M.E., and C. Both. 2005. Shifts in phenology due to global climate change: the need for a yardstick. Proceedings of the Royal Society B: Biological Sciences 272: 2561-2569.

Weltzin, J. F. 2011. The USA National Phenology Network; taking the pulse of our planet. US Geological Survey 3023.

Wiggins, A., and Crowston, K. 2011. From conservation to crowdsourcing: A typology of citizen science. System Sciences (HICSS), 2011 44th Hawaii international conference 1-10. IEEE.

van Vliet, A.J., de Groot, R.S., Bellens, Y., Braun, P., Bruegger, R., Bruns, E., Clevers, J., Estreguil, C., Flechsig, M., Jeanneret, F. and Maggi, M., 2003. The European phenology network. International Journal of Biometeorology 47: 202-212.

Zelt, J., Courter, J., Arab, A., Johnson, R., \& Droege, S. 2012. Reviving a legacy citizen science project to illuminate shifts in bird phenology. International Journal of Zoology 2012: 8692. 
Table 1. Outreach methods used to find sources of data for the West Virginia Climate History Project.

\begin{tabular}{|c|c|c|}
\hline Outreach Method & Date & $\begin{array}{c}\text { Estimated \# People } \\
\text { Reached }\end{array}$ \\
\hline $\begin{array}{l}\text { Fliers to individuals and } \\
\text { public libraries (85) }\end{array}$ & March-April 2015 & 100 \\
\hline $\begin{array}{c}\text { West Virginia University } \\
\text { Press Release }\end{array}$ & March 312015 & 100 \\
\hline Blog started & May 12015 & 3090 \\
\hline $\begin{array}{l}\text { Brooks Bird Club Annual } \\
\text { Foray Presentation }\end{array}$ & June 92015 & 30 \\
\hline $\begin{array}{l}\text { West Virginia Master } \\
\text { Naturalist Presentation }\end{array}$ & August 132015 & 20 \\
\hline $\begin{array}{l}\text { West Virginia NPR } \\
\text { Interview }\end{array}$ & October 152015 & 500 \\
\hline $\begin{array}{l}\text { Allegheny Highlands } \\
\text { Climate Change Impacts } \\
\text { Initiative Presentation }\end{array}$ & October 172015 & 100 \\
\hline $\begin{array}{c}\text { The Wildlife Society West } \\
\text { Virginia Chapter Meeting } \\
\text { Presentation }\end{array}$ & December 42015 & 25 \\
\hline $\begin{array}{l}\text { Brooks Bird Club Annual } \\
\text { Foray Presentation }\end{array}$ & June 192016 & 30 \\
\hline $\begin{array}{l}\text { Mountaineer Audubon } \\
\text { Meeting Presentation }\end{array}$ & October 112016 & 25 \\
\hline Total & & 4020 \\
\hline
\end{tabular}


Table 2. Phenophases and number of phenology observations found with the West Virginia Climate History Project.

\begin{tabular}{|c|c|c|}
\hline Phenophase & Qualifier & $\begin{array}{c}\text { No. of } \\
\text { Observations }\end{array}$ \\
\hline Active Individuals & & 13 \\
\hline Adults Vocalizing & & 3 \\
\hline Breaking Leaf Buds & & 8 \\
\hline Calls or Song & & 8 \\
\hline Colored Leaves & & 21 \\
\hline Egg Laying & & 1 \\
\hline Eggs Hatch & & 3 \\
\hline Eggs Present & & 47 \\
\hline Fall Migration & & 383 \\
\hline & $\begin{array}{l}\text { First Seen } \\
\text { Peak } \\
\text { Last Seen }\end{array}$ & \\
\hline Falling Leaves & & 5 \\
\hline Feeding & & 2 \\
\hline Flowers & & 751 \\
\hline & $\begin{array}{l}\text { Buds } \\
\text { First } \\
\text { Peak } \\
\text { Past }\end{array}$ & \\
\hline Fruits & & 2 \\
\hline Initial Growth & & 13 \\
\hline Leaves & & 8 \\
\hline Males Vocalizing & & 18 \\
\hline Mating & & 6 \\
\hline Nest Building & & 5 \\
\hline Recent Seed Drop & & 3 \\
\hline Ripe Fruits & & 13 \\
\hline Spring Migration & & 5,799 \\
\hline & $\begin{array}{l}\text { First Seen } \\
\text { Last Seen }\end{array}$ & \\
\hline Tadpoles & & 1 \\
\hline Young Individuals & & 63 \\
\hline Young Leaves & & 5 \\
\hline Total & & 7,181 \\
\hline
\end{tabular}




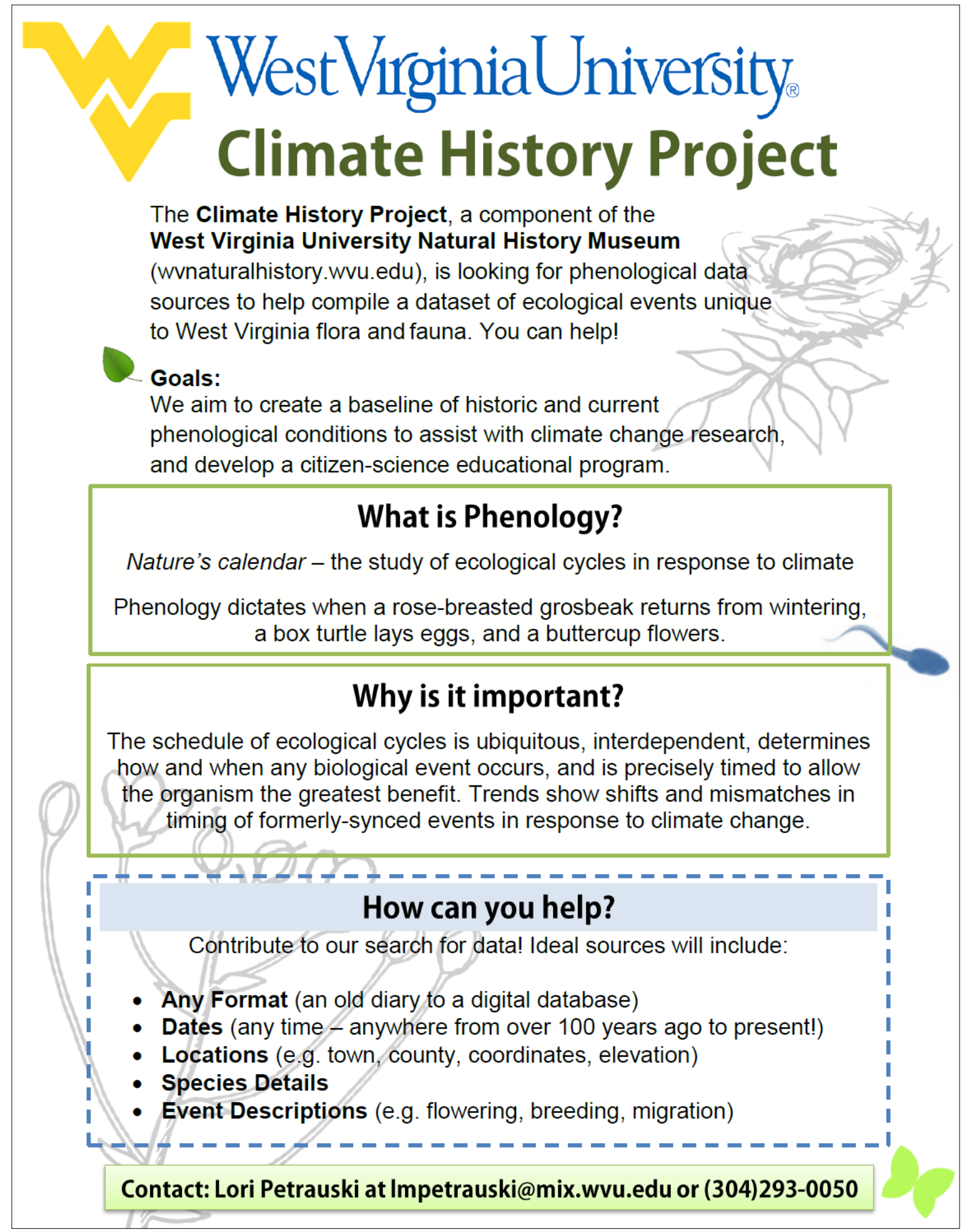

Figure 1. Flyer sent to public libraries and people with potential phenology data in West Virginia. 


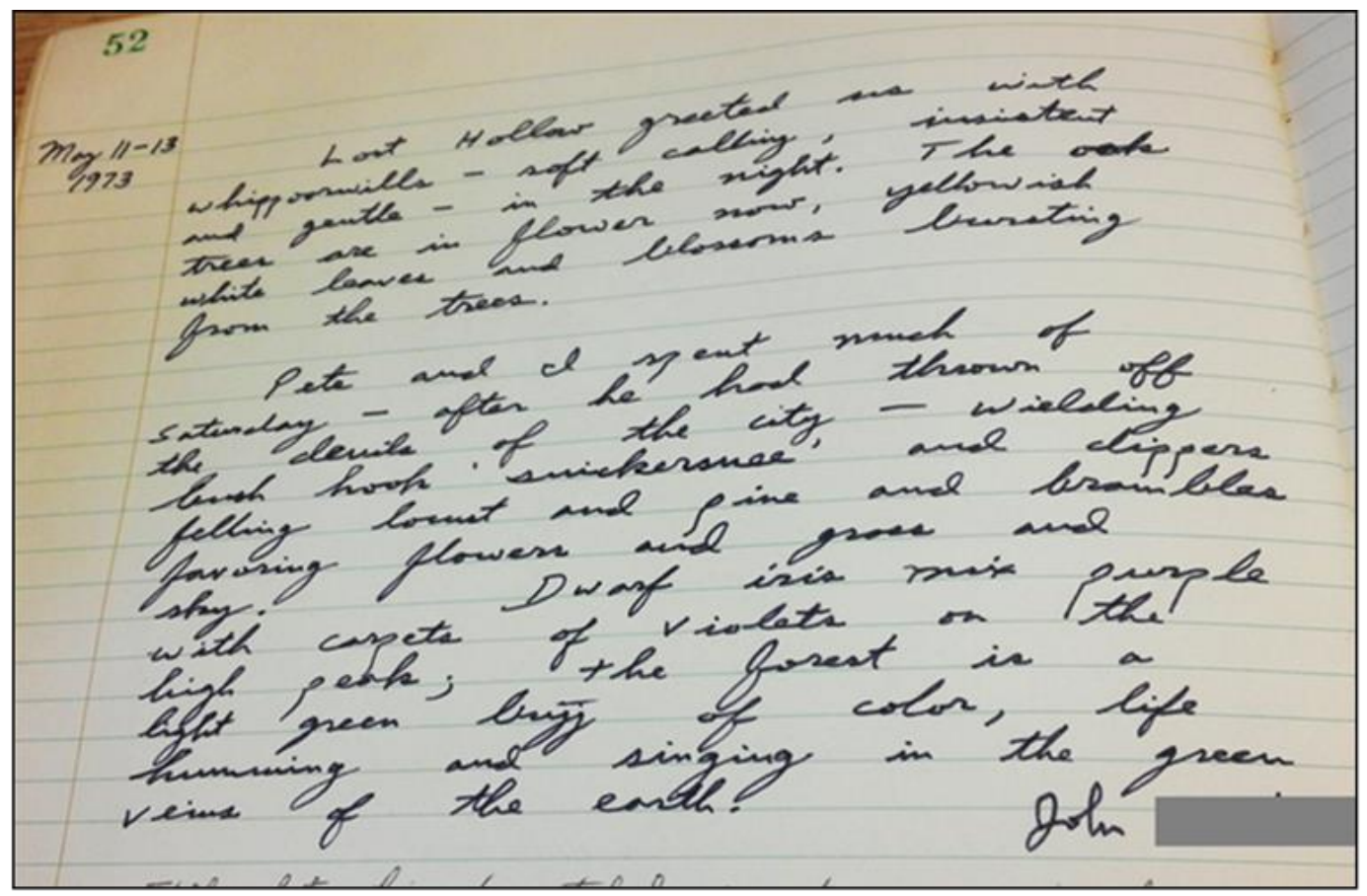

Figure 2. Excerpt from a personal journal from Hardy County, West Virginia in May 1973 that was used for data collection. 


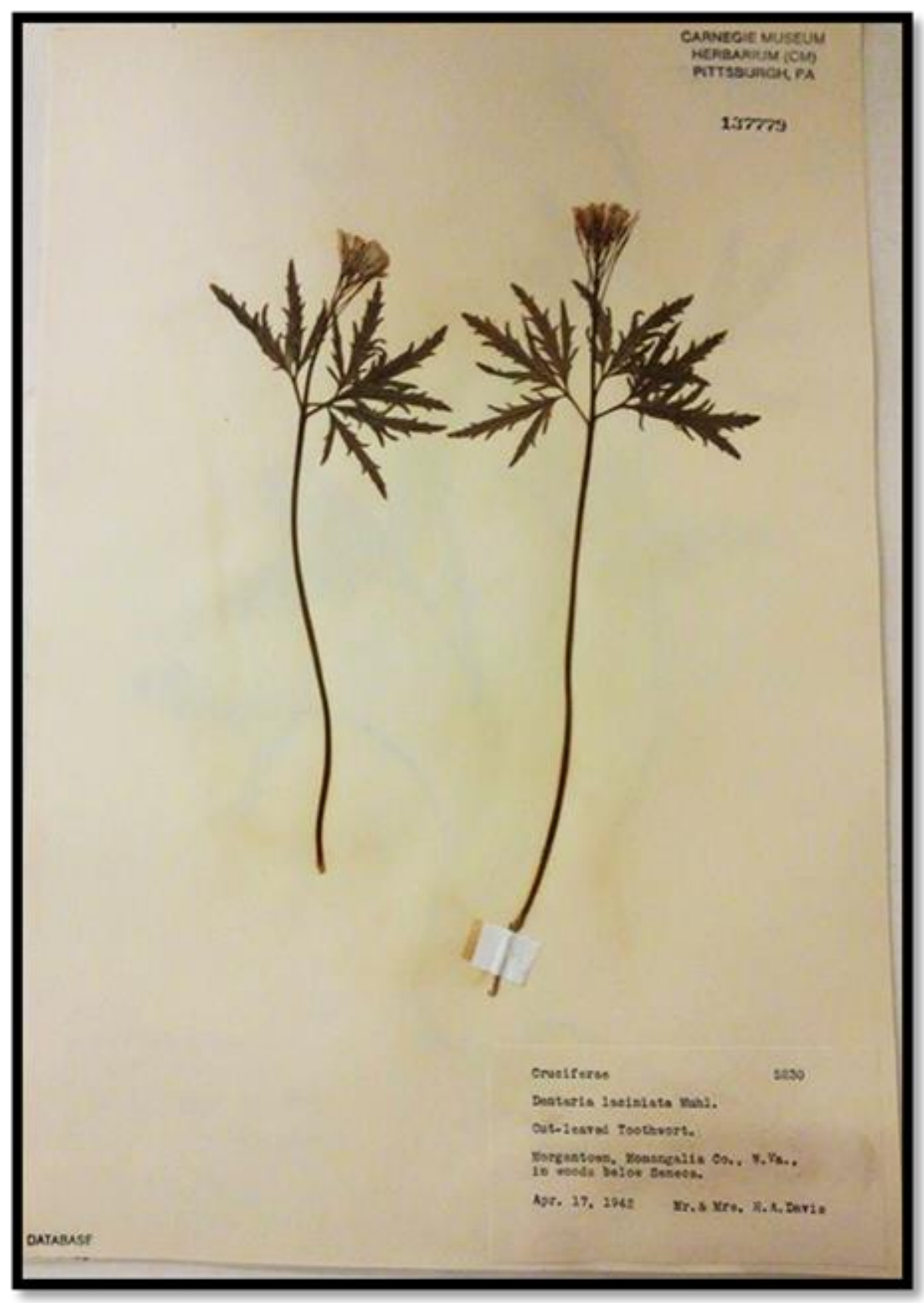

Figure 3. Example of a herbarium specimen used for data collection. This is a pressed Cutleaf Toothwort from Monongahela County, West Virginia in 1942 from the Carnegie Museum of Natural History in Pittsburgh, Pennsylvania. 


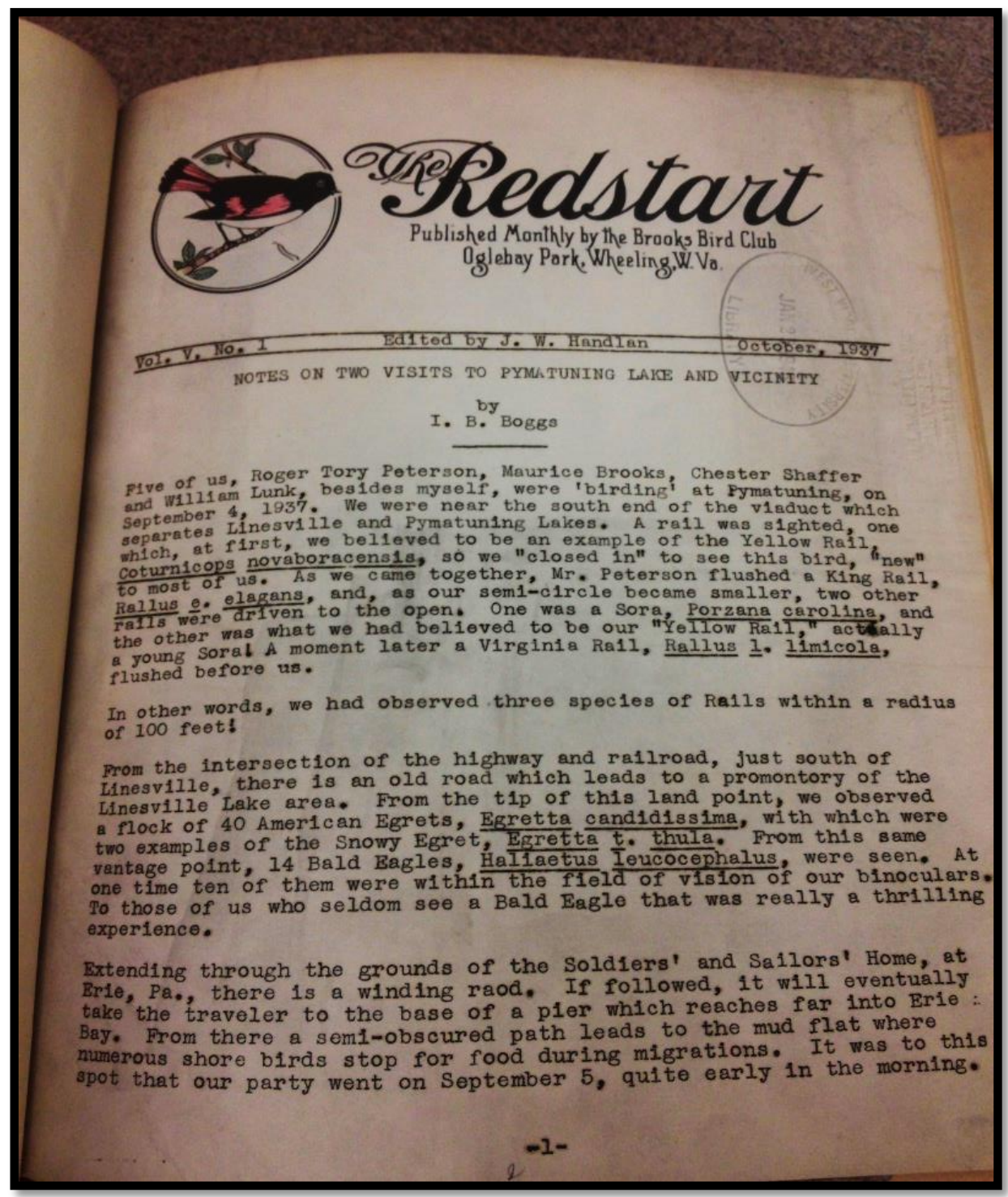

Figure 4. The front page of The Redstart from 1937, the official publication of the Brooks Bird Club, which was used for data collection. 


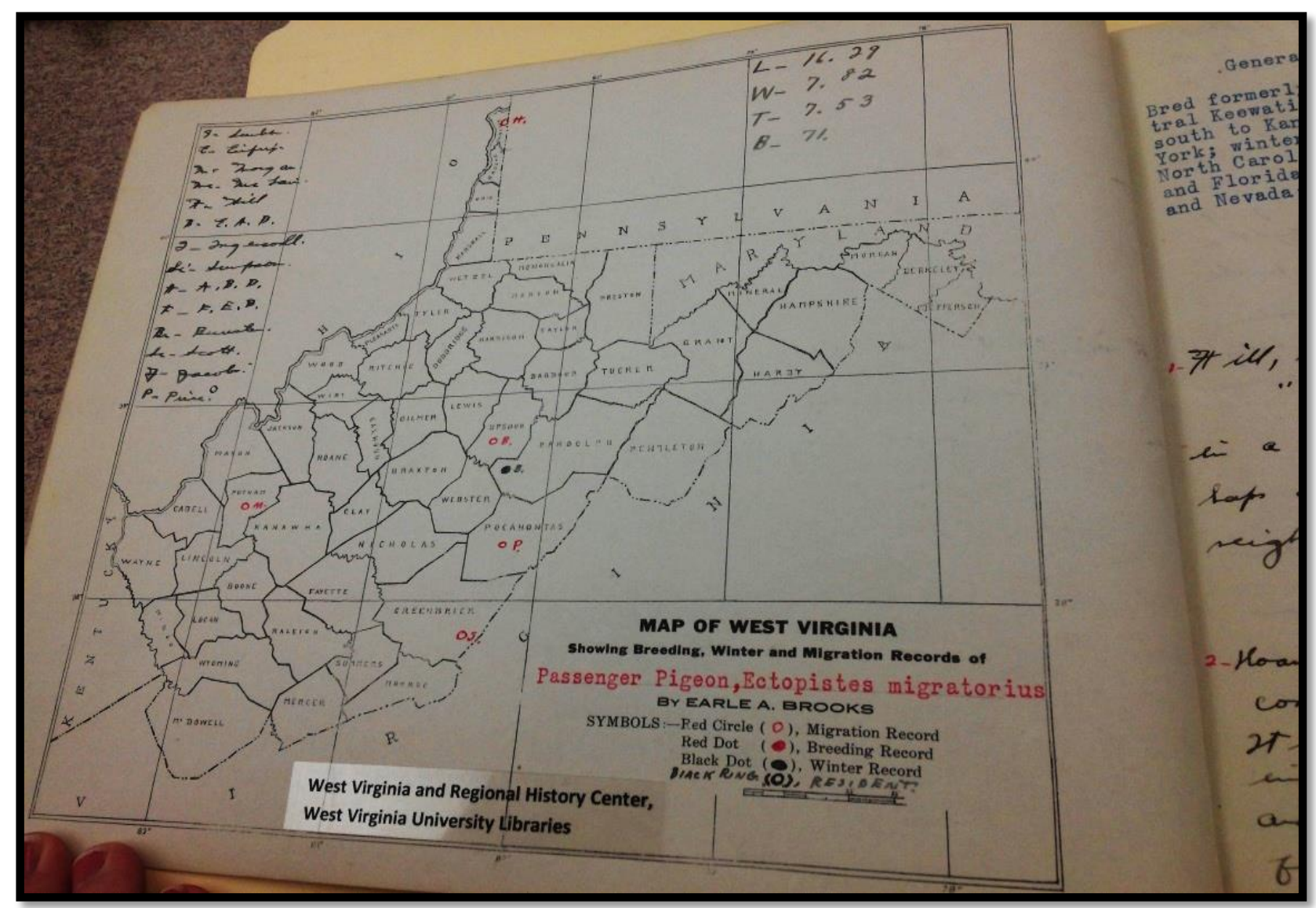

Figure 5. Map of observations of the Passenger Pigeon Ectopistes migratorius made by Earl Brooks between 1890 and 1915, which is housed in the West Virginia Regional History Center in Morgantown, West Virginia. 


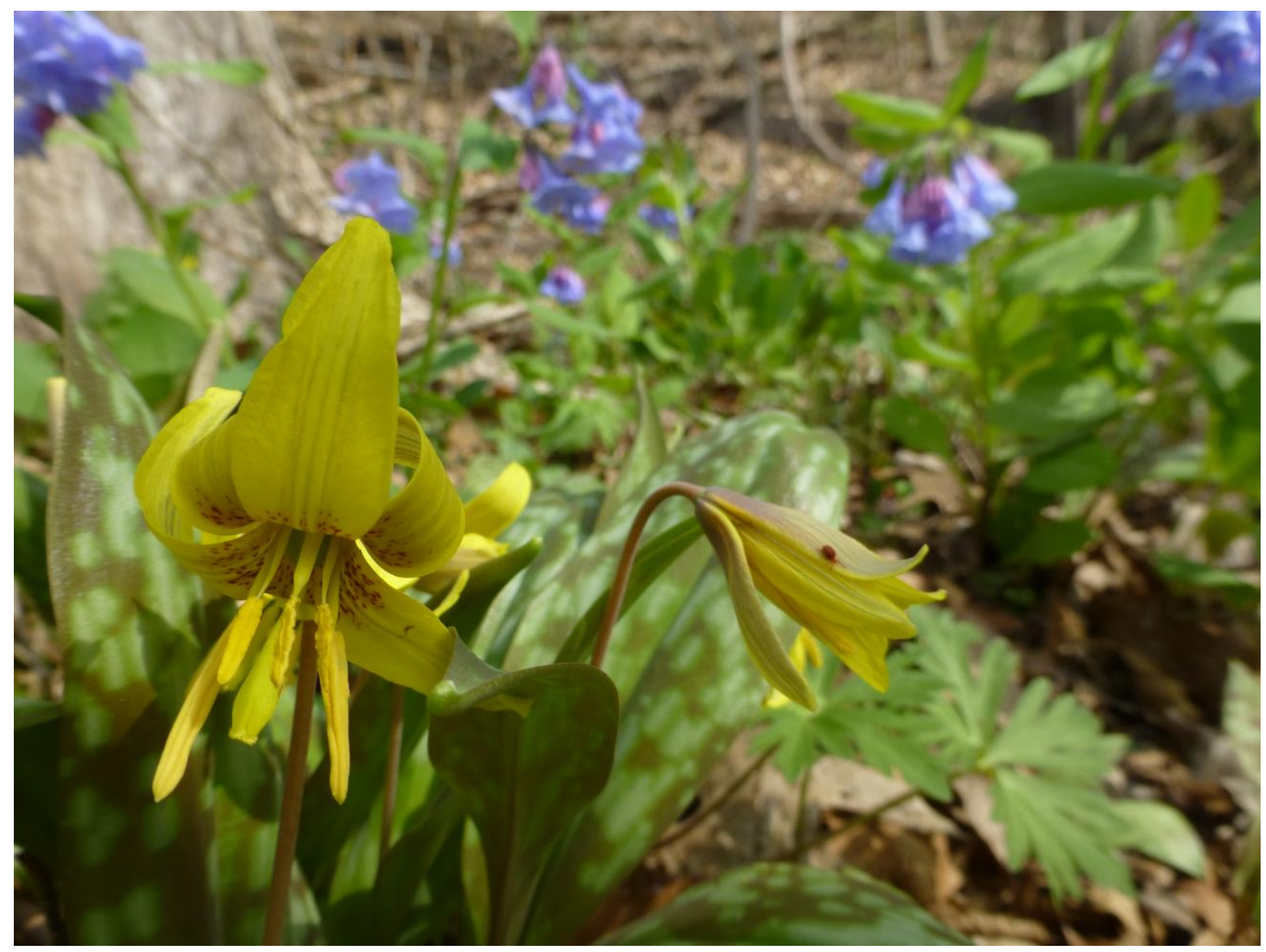

Figure 6. Personal photograph of Yellow Trout Lily Erythronium americanum and Virginia Bluebells Mertensia virginica in the Core Arboretum, Morgantown, West Virginia on April 14, 2014 by David Smaldone. Dated photographs such as this were used in data collection. 


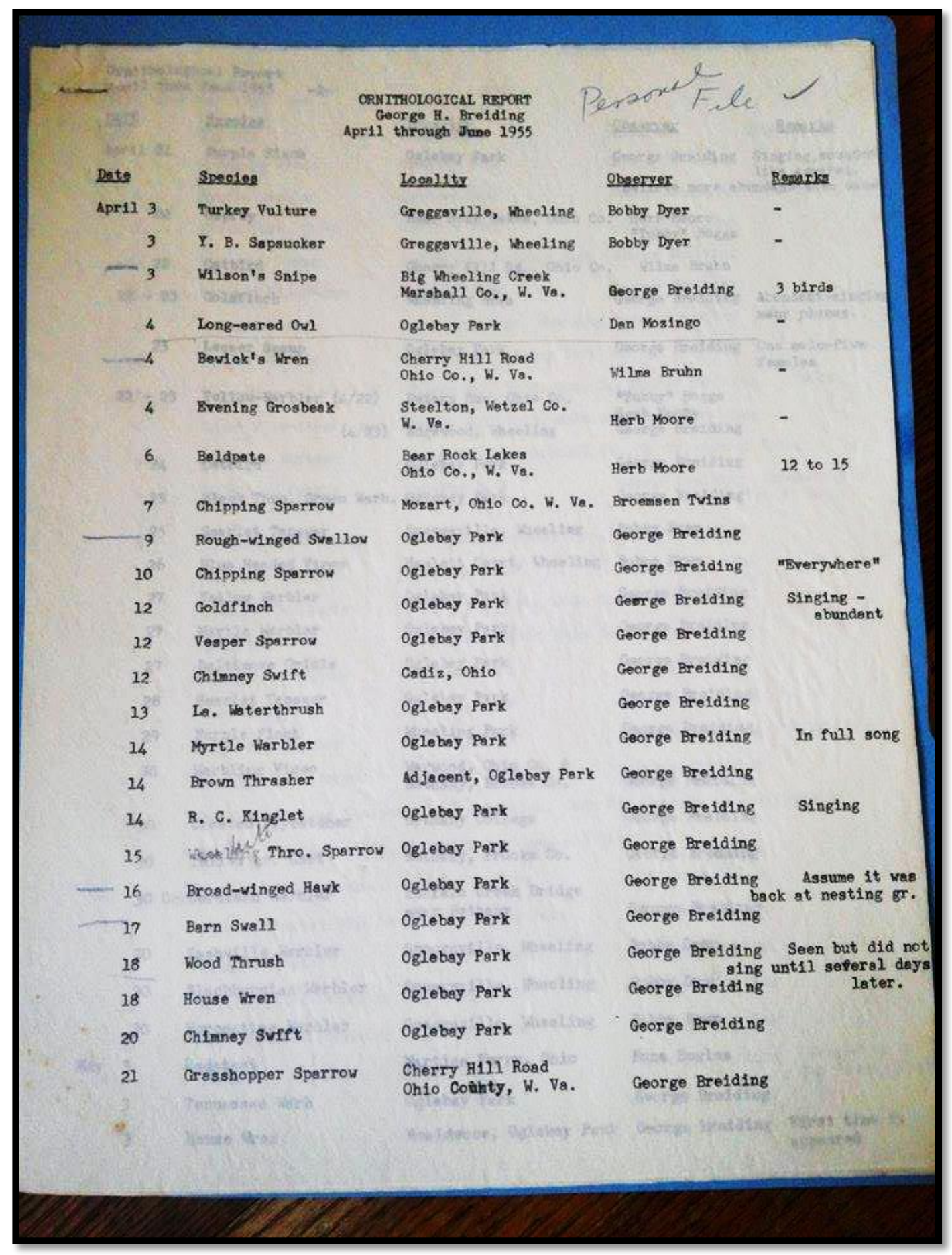

Figure 7. Typed bird list collected by George Brieding of Wheeling, West Virginia in 1955. 


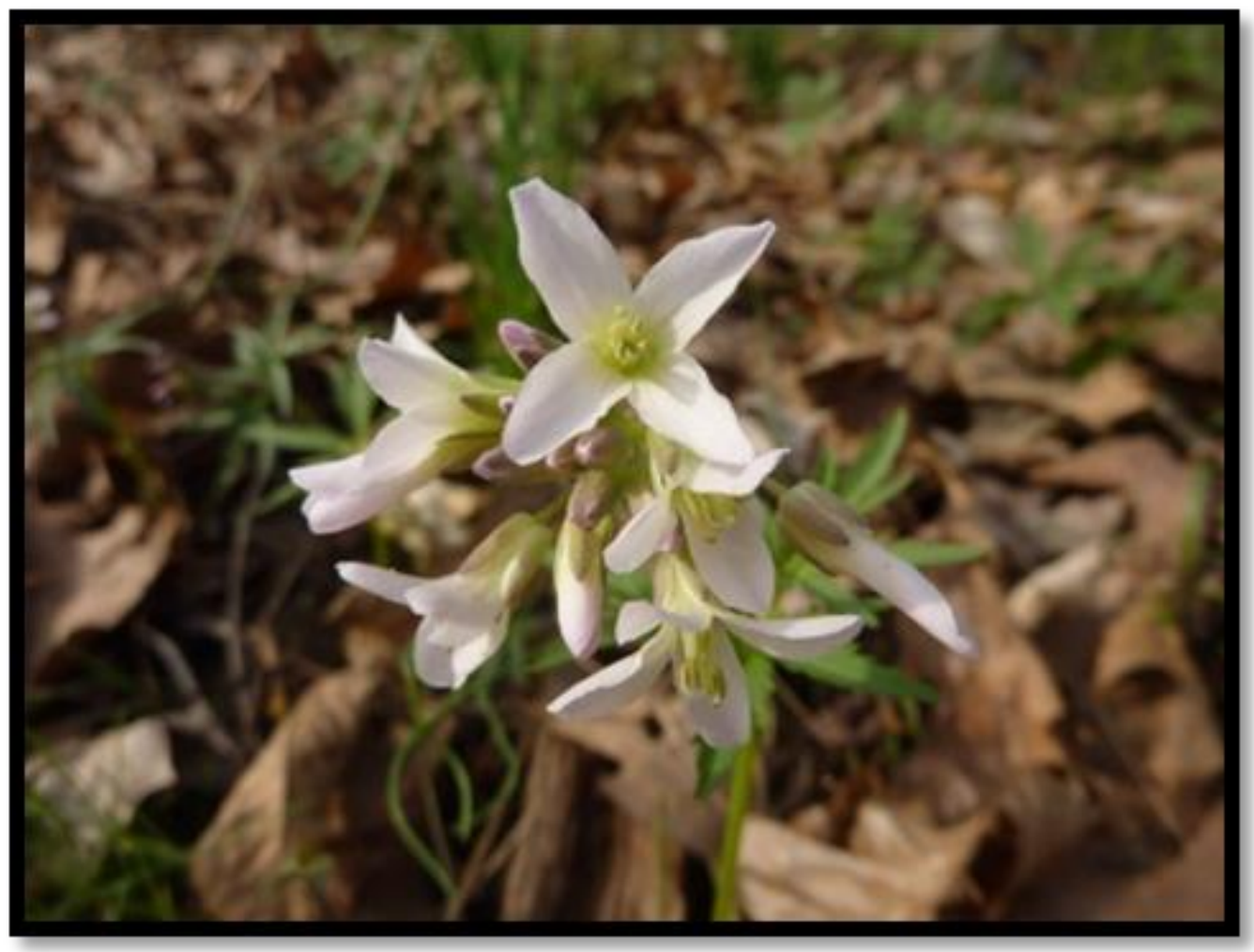

Figure 8. Photograph of Cutleaf Toothwort Cardamine concatenata by David Smaldone. 


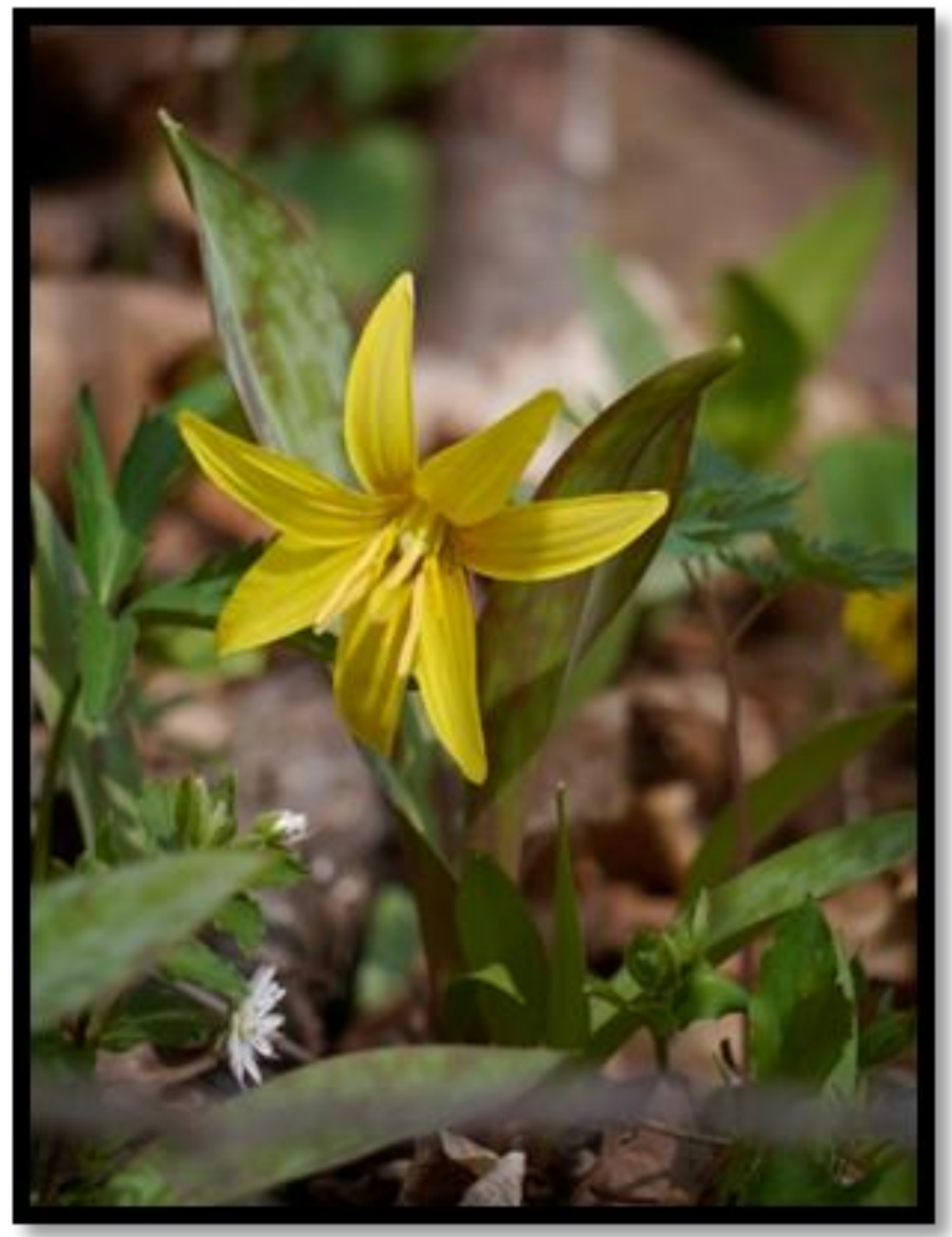

Figure 9. Photo of Yellow Trout Lily Erythronium americanum by David Smaldone. 


\section{CHAPTER 2}

\section{Developing a Historical Phenology Dataset Through Community Involvement for Climate Change Research}

Lori Petrauski ${ }^{1}$, Sheldon Owen ${ }^{2}$, George Constantz $^{3}$, Thomas Rodd ${ }^{4}$ and James T. Anderson ${ }^{1}$

${ }^{1}$ Division of Forestry and Natural Resources, West Virginia University, Morgantown, WV 26506

${ }^{2}$ West Virginia University Extension Services, Morgantown, WV 26506

3351 N. Back Creek Rd., High View WV 26808

${ }^{4}$ Friends of Blackwater, Davis, WV 26260

Keywords: historical phenology, community phenology, citizen science, conservation phenology

Written in the style of: Conservation Biology 


\section{Acknowledgements}

We thank the many people who contributed observations and access to data, including the Brooks Bird Club, Mike Breiding, the West Virginia Regional History Center, eBird, Carnegie Museum of Natural History, West Virginia University Herbarium, Fairmont State University Herbarium, University of Charleston Herbarium, George B. Rossbach Herbarium, Marshall University Herbarium, David Smaldone (Recreation, Parks, and Tourism Resources, West Virginia University), and Andrew Walker (Potomac State University). We also thank Greg Good (American Institute of Physics) for ideas and logistics. Funding and logistical support was provided by the U.S. Department of Agriculture Northeast Climate Hub, the West Virginia Humanities Council, and the West Virginia University Natural History Museum. This is manuscript number xxxx of the West Virginia University Agriculture and Forestry Experiment Station.

\footnotetext{
Abstract:

There has been an increased effort to utilize untapped sources of historical phenological data such as museum specimens, journals written by nature-minded citizens, and dated photographs through local phenology projects for climate change research. Local phenology projects have contributed greatly to our current understanding of phenological changes over time and have an important role in the public's engagement with natural history, but there are also significant challenges in finding and analyzing historical data. The West Virginia Climate History Project collected historical phenology data $(1890$ - 2015) from citizens in West Virginia with scientifically and culturally relevant results. We discuss the development of the project, issues we overcame, recommendations for future projects, and the conservation value of local phenology projects. Local phenology projects lend value to climate change research and
} 
conservation education. Policy directed towards supporting humanities grants and museum collections, including herbariums, is crucial in the success of these projects.

\section{Introduction}

Phenology, the timing of biological events in relation to seasons, has become popular due to its public accessibility (Lawrence 2009), potential for scientific education (Bonney et al. 2009), and use in tracking responses to climate change (Visser \& Both 2005). With the rise of phenology, there is a need to uncover historic phenology data so researchers can track changes over time. There has been a surge in attempts by researchers to utilize untapped sources of historical phenological data such as museum specimens, journals written by nature-minded citizens, and dated site-specific photographs (Miller-Rushing et al. 2006; Ellwood et al. 2010; Primack \& Miller-Rushing 2012).

Historical phenological observations have been used to create baselines for bird migration (Zelt et al. 2012; Travers et al. 2015), first flowering dates (Miller-Rushing et al. 2008; Abu-Asab et al. 2001), and leaf-out dates (Everill et al. 2014; Polgar and Primack 2013). Researchers have used phenological data found in journals of naturalist-minded authors as a baseline to compare with current dates of phenological events to estimate how climate change is affecting the timing of phenophases (Bradley et al. 1999; Polgar and Primack 2013). These isolated studies, which involve local communities in research on familiar flora and fauna, are important for understanding individual organisms' responses to changes in climate.

Currently, the USA National Phenology Network (USA-NPN) attempts to synthesize data from individuals and small phenology projects, increase internetwork communication, and promote the practical use of phenological data (van Vliet et al. 2003; Rosemartin et al. 2014), as well as increase public awareness of phenology, climate change, and the scientific process 
(Haggerty and Mazer 2008, Meymaris 2008). However, the implementation of these databases is relatively recent (USA-NPN was created in 2007) and establishing baseline data is still a challenge for phenological research (Betancourt et al. 2007; Miller-Rushing et al. 2010; Weltzin 2011). Researchers have had to use creative methods to gather long-term baseline data, including the use of herbarium specimens, observations from diaries, and photographs (Miller-Rushing et al. 2006).

There is a need for long-term phenological datasets in West Virginia to assess the current and future effects of climate change, as well as to set the stage for future citizen science projects. These were the goals of the West Virginia Climate History Project (WVCHP). Previous longterm studies have been done using historical observations from well-known people such as Henry David Thoreau (Miller-Rushing and Primack, 2008) or Aldo Leopold (Bradley et al. 1999), but this project demonstrates that reliable, long-term datasets can be found in any area with observant citizens. The purposes of this paper are to outline the WVCHP, advise other local phenological projects, and discuss the conservation value of local phenology projects.

\section{Uncovering and Processing Historical Sources}

The WVCHP began with public outreach in January 2015, in the hopes of finding individuals with archival sources of phenology data. Through presentations with local naturalist groups, informational fliers sent to public libraries, a press release through the university, an online project blog, and a West Virginia Public Radio interview, we attempted to reach interested citizens and find leads on potential data. With each outreach effort, we were offered suggestions, email addresses, and names of other people to contact for assistance with the project.

The most significant breakthrough in finding phenological data was the start of our relationship with the Brooks Bird Club, a naturalist group in West Virginia that was founded in 
1932. The club's official publication, The Redstart, was the single most data-rich source used during this project. Our communications with their current members led us to other individuals with excellent historical records. Relationships we forged with local naturalist groups contributed to the success of this project more than any other factor; $78 \%$ ( $n=5614$ observations) of the data gathered through this project were directly related to these relationships.

Once the data sources were located, the task of transcribing the records began. Transcribing data from handwritten notes, journals, and lists ( $24 \%$ of the data, $\mathrm{n}=1350$ observations) required patience and investigative skills; whereas capturing data from newsletters, lists, or herbarium-labels was more efficient. The species, location, date, and phenophase were recorded for each phenological observation into an electronic format. One issue we encountered when working with these sources was the question of the difference between a phenological and a biological observation. For example, an entry in a personal journal could mention an American black bear (Ursus americanus) sighting in West Virginia, but the observation is not associated with seasonality. On the other hand, a journal entry that notes a bear with a young cub would have merit as a breeding phenology observation. We recorded phenophases and their definitions based on guidelines set by the USA-NPN (Denny et al. 2014).

At the start of our project, we had no preferences for specific species, phenophase, or season. After we discovered the first several sources, we saw the most potential in finding data regarding avian spring migration and spring wildflower blooming. Our interest in avian phenology was inspired by the Brooks Bird Club and the data potential of herbarium specimens triggered our interest in wildflower phenology. Advantages of using herbarium specimens for phenological studies include large temporal coverage, geographic area, and availability of valuable data plus reliable metadata (Vellend et al. 2013). Most of our search was focused on 
where we could find first arrival dates of migrating birds through West Virginia and flowering dates of spring ephemeral wildflowers, which describes much of the data collected. We collected phenological data from personal journals, dated photographs, personal birding lists, herbarium specimens, Brooks Bird Club records, and history center collections (Table 1) as long as they were accompanied by sufficient metadata.

Once we began analyzing specific phenophases and species, we had to overcome the issues associated with combining datasets from multiple observers. Observer skill, time taken each week for observation, and distance covered during observation could differ among observers and bias the data (Miller-Rushing et al. 2008). Phenology data are especially prone to this issue due to the sensitivity to timing of these observations. For both analyses, avian first arrival dates and wildflower blooming dates, the data sources were evaluated for credibility and accuracy before combining the datasets. Specifically for first arrival dates, more observers may result in seemingly earlier arrival dates (Courter et al. 2013; Arab et al. 2016). We reconciled our avian sources with these issues by arguing that all observers were experienced naturalists who visited a variety of habitats to observe migrating species and that the data from each source were gathered by groups of people more often than by single individuals, which improved consistency among sources. Similar avian datasets from multiple observers and sources have been analyzed together with defensible results (Ellwood et al. 2010; Travers et al. 2015).

Possible issues with the wildflower blooming analyses were reduced by choosing species with a short blooming-window of one to two weeks, which negated problems associated with "first" phenophase analyses. The main concern we faced with analyzing blooming dates was identifying locations of each blooming observation to calculate elevation and local climatic conditions. The location information offered on herbarium labels was used to pinpoint blooming 
locations with ArcGIS Version 10.3, but the level of detail varied for each location description.

This variation in detail increased the likelihood that factors such as hillshade and aspect, which have been shown to explain variation in flowering phenology (Jackson 1966), could be confounding variables. Still, the high number of flowering observations analyzed was sufficient to overcome sampling bias within the data (Primack et al. 2004). Overall, issues with combining historical datasets should be evaluated on a case-to-case basis that depend on the phenophase and species being analyzed.

\section{Conservation Value}

Local phenology projects have contributed greatly to understanding phenological changes over time (Ellwood et al. 2010; Travers et al. 2015; McDermott \& DeGroote 2016), and have an important role in the public's engagement with natural history (Primack \& Miller-Rushing 2012). Local phenology projects are especially relevant in the context of climate change (Dickinson et al. 2012), due to their contribution to recovering long-term phenological data (Morellato et al. 2016) and the connection between phenology and climate change (Root et al. 2003). Because recording phenological data is relatively straight-forward, phenology attracts a wide range of people with varying scientific experience, and therefore can impact how people understand climate change (Lawrence 2009). Local phenology projects can take advantage of this accessibility and offer a rare connection between familiar organisms and a global context.

The data collected by local phenology projects can be scientifically and culturally significant. Education and engagement of the public with climate change issues remain key components in the future success of conservation efforts (Burch et al. 2014). Additionally, historical insights into species loss, changes in plant communities, the effects of land-use change, and urbanization are unique to each locality and can be used as a public reflection of human 
impacts on familiar places (Haywood 2014). Specifically, the WVCHP encompassed a large, topographically variable area $\left(62,259 \mathrm{~km}^{2}\right.$, covering four ecoregions, average elevation $=420 \mathrm{~m}$, elevation range $=73-1,482 \mathrm{~m})$ across a great temporal extent $(1890-2015)$. Such scope is a common advantage of citizen science projects and makes this type of research important for conservation biogeography (Devictor et al. 2010). This project enabled us to collect data on private lands, which pose increased challenges for traditional sampling methods (Dickinson et al. 2010).

Long-term phenological datasets can be used to explore how relationships between native and invasive species phenologies may influence management practices (Wolkovich \& Cleland 2011), such as the scheduling of prescribed burning (Benefield et al. 2001) and herbicide application (Xu et al. 2007). In these cases, understanding that the phenologies of native and invasive plants has facilitated improved management practices to protect native species and prevent the spread of invasives. Local historical phenology datasets can be used to understand the makeup of past plant communities (Miller-Rushing \& Primack 2008), predict future competitive advantages of native and invasive plants (Polgar and Primack 2013), and give valuable perspectives on the locale effects of invasive species (Crall et al. 2015; Hoffberg and Mauricio 2016).

Many studies linking phenology to climate change focus on sweeping conclusions that do not specifically address local management actions (Enquist et al. 2014), but we argue that local phenology projects can be used to impact management, especially if it is prioritized at the beginning of the project. For example, determining historical patterns of phenology to predict future changes in migration or breeding of game birds could help optimize hunting seasons (Guzmán and Arroyo 2015). Similarly, exploring the historical relationships between 
temperature, aquatic insect emergence, and fish spawning could contribute to revising fishing regulations and identifying potential threats to aquatic ecosystems (Donnelly et al. 2011).

Climate-driven phenological mismatches could affect local populations including those species that are already threatened (Robinson et al. 2009), such as the Cerulean Warbler (Setophaga cerulea) in the Central Appalachians that relies on mature forests for breeding. The ability to predict the vulnerability to climate change of certain species is a crucial first step for adjusting local management actions.

For example, the West Virginia white butterfly Pieris virginiensis, a rare butterfly found in the Central Appalachians, has been declining in part because of the spread of exotic garlic mustard (Alliaria petiolata) throughout their range. A. petiolata is in the same family (Brassicaceae) as $P$. virginiensis's host plants, and $P$. virginiensis lays its eggs on $A$. petiolata where the larva cannot survive therefore negatively impacting butterfly reproduction. Understanding the phenology patterns of both A. petiolata and P. virginiensis would allow for better local management of both the threatened butterfly and the invasive plant. For example, $A$. petiolata control should be implemented in early spring before the emergence of $P$. virginiensis.

Butterflies have shifted their phenologies three times more than spring plants in recent years (Parmesan 2007). Butterfly species shift their emergence phenology relative to temperature (Kharouba et al. 2014), but their response to changes in climate is highly dependent on their larval host species (Posledovich et al. 2015). Understanding not only flowering patterns, but also butterfly phenology in relation to climate change is important for pollinator conservation (Davis and Cipollini 2014). For example, $P$. virginiensis depends on early flowering species for food and oviposition. The early flowering species, Cardamine diphylla, is a common host plant of $P$. virginiensis. The early senescence of $C$. diphylla has resulted in decreased larval survival 
or reproductive success of $P$. virginiensis. A local phenology project investigating this host plant and butterfly mismatch could increase the success of managing a threatened species.

\section{Evaluation and Recommendations for Future Projects}

Overall, the WVCHP collected 7181 historical phenology observations covering 404 different species, including 258 bird species, 37 species of trees and shrubs, 100 species of herbs and forbs, 2 insect species, 1 mammal, 3 amphibian species, and 3 grasses. Most of the observations $(80.2 \%)$ were used to analyze avian spring migration and wildflower blooming. The remaining $19.8 \%$ covers a range of species and phenophases that we were unable to analyze due to too few consistent observations.

The success of this project in finding useful avian and wildflower phenology data is due to our concentrated focus on these two categories. This highlights the potential for more phenological data to be uncovered in this region, if a focus is set on particular species and phenophases. We expect that there are more useable data in this region that we have not had the opportunity to compile. Phenological information about spring insect emergence would contribute to our understanding of ecosystem phenology and the potential risks of mismatch, because insects are a link between avian and plant phenologies (Primack \& Miller-Rushing 2012), both of which have been studied more thoroughly than insect phenology.

One of the greatest potential sources of phenological data is herbarium specimens, which has been highlighted in recent literature (Gaira et al. 2011; Calinger et al. 2013; Everill et al. 2014) and confirmed with this study. Herbariums are rich sources of phenological information that can be used to evaluate species presence and geographic distributions (Vellend et al. 2013). There is a disconnected relationship between the usefulness of herbarium specimens for research and the amount of funding given to enhancing these collections. There has been a decrease in funding for herbariums over the last few decades (Ahrends et al. 2011) despite an increase in 
using herbarium specimens as data sources (Lavoie 2013). Digitizing herbarium specimens has increased the usefulness and availability of these data and has contributed to the increased use of herbarium specimens in research. Unfortunately, small collections are seldom cataloged due to tight budgets, which makes them difficult to access (Deng 2015). Another issue facing herbariums is a decrease in addition of new plant specimens (Prather et al. 2004; Beauvais et al. 2017), which could be contributing to the antiquated reputation of herbariums and their subsequent decrease in funding. The herbariums used in this study were strewn throughout West Virginia in various universities with no central herbarium database or consistent organization. Using herbarium specimens from these under-utilized and hard-to-access collections increased the distinctiveness and temporal range of our dataset. This demonstrates the value of small herbariums and the importance of continued funding for maintaining and growing herbariums and museum collections.

Humanities grants have also experienced decreases in funding, but we argue that these grants play an important role in local phenology projects and ensuing climate change research. Historical personal journals were a key source of phenology data in this study, and humanities grants allow for libraries to preserve these irreplaceable data points. The handwritten journals we uncovered carried both cultural and scientific significance that enriched the breadth of our project, which highlights the importance of funding for humanities grants.

We did not encounter a shortage of historical data, but finding current data in handwritten journals and herbariums was more difficult. To create a complete temporal dataset, we used alternative data sources to augment our current phenological observations. For our avian analysis, we supplemented current data with observations from eBird, an online community of birders (Sullivan et al. 2009). For the wildflower analysis, we used dated photographs from a 
West Virginian citizen to increase the number of current blooming observations. The increased use of electronic phenological monitoring programs, such as Project BudBurst (2017) and Nature's Notebook, are instrumental sources of current data that should be integrated with historical phenological data.

Local phenology projects are categorized as citizen science (Wiggins \& Crowston 2011), but unless there is substantial effort to include educational outcomes and create educational materials, there is little evidence that the project will have educational impacts (Bonney et al. 2009; Dickinson et al. 2010; Dickinson et al. 2012). The main outcomes of this project were scientific with potential to develop educational outcomes in the future. We recommend establishing strong education outcomes for future projects that could include recruiting volunteers to process historical data sources, developing educational materials, and creating a volunteer monitoring component to supplement current observations of specific species of interest to the community. As previously stated, our relationship with the Brooks Bird Club and other naturalist groups contributed significantly to the success of this project, which highlights the importance of public outreach and communication.

The West Virginia Climate History Project has demonstrated the usefulness of a local phenology project for uncovering previously unused phenological data, engaging local communities with climate change research, and finding scientifically relevant insights about the effects of climate change on ecosystems. Local phenology projects have a pertinent role in the future of climate change research and conservation education. Policy directed towards supporting humanities grants and museum collections, including herbariums, is crucial in the success of these projects. 


\section{Literature Cited:}

Abu-Asab MS, Peterson PM, Shetler SG, Orli SS. 2001. Earlier plant flowering in spring as a response to global warming in the Washington, DC, area. Biodiversity and Conservation 10:597-612.

Ahrends A et al. 2011. Conservation and the botanist effect. Biological Conservation 144:131140.

Arab A, Courter JR, Zelt J. 2016. A spatio-temporal comparison of avian migration phenology using Citizen Science data. Spatial Statistics 18:234-245.

Beauvais MP, Pellerin S, Dubé J, Lavoie C. 2017. Herbarium specimens as tools to assess the impact of large herbivores on plant species. Botany 95:153-162.

Benefield CB, DiTomaso JM, Kyser GB, Tschohl A. 2001. Reproductive biology of yellow starthistle: maximizing late-season control. Weed Science 49:83-90

Betancourt JL et al. 2005. Implementing a US national phenology network. Transactions American Geophysical Union 86:539-541.

Bonney R, Cooper CB, Dickinson J, Kelling S, Phillips T, Rosenberg KV, Shirk J. 2009. Citizen science: a developing tool for expanding science knowledge and scientific literacy. BioScience 59:977-984.

Bradley NL, Leopold AC, Ross J, Huffaker W. 1999. Phenological changes reflect climate change in Wisconsin. Proceedings of the National Academy of Sciences 96:9701-9704.

Burch S, Berry P, Sanders M. 2014. Embedding climate change adaptation in biodiversity conservation: A case study of England. Environmental Science \& Policy 37:79-90.

Calinger KM, Queenborough S, Curtis PS. 2013. Herbarium specimens reveal the footprint of climate change on flowering trends across north-central North America. Ecology Letters 16:1037-1044.

Crall AW, Jarnevich CS, Young NE, Panke BJ, Renz M, Stohlgren TJ. 2015. Citizen science contributes to our knowledge of invasive plant species distributions. Biological Invasions 17:2415-2427. 
Courter JR, Johnson RJ, Stuyck CM, Lang BA, Kaiser EW. 2013. Weekend bias in Citizen Science data reporting: implications for phenology studies. International Journal of Biometeorology 57:715-720.

Davis S, Cipollini D. 2014. How environmental conditions and changing landscapes influence the survival and reproduction of a rare butterfly, Pieris virginiensis (Pieridae). Journal of the Lepidopterists' Society 68:61-65.

Deng B. 2015. Plant collections get pruned back: North America's herbaria wilt under budget pressure. Nature 523:16.

Denny EG, et al. 2014. Standardized phenology monitoring methods to track plant and animal activity for science and resource management applications. International Journal of Biometeorology 58:591-601.

Devictor V, Whittaker RJ, Beltrame C. 2010. Beyond scarcity: citizen science programmes as useful tools for conservation biogeography. Diversity and Distributions 16:354-362.

Dickinson JL, Zuckerberg B, Bonter DN. 2010. Citizen science as an ecological research tool: challenges and benefits. Annual Review of Ecology, Evolution, and Systematics 41:149172.

Dickinson JL, Shirk J, Bonter D, Bonney R, Crain RL, Martin J, Phillips T, Purcell K. 2012. The current state of citizen science as a tool for ecological research and public engagement. Frontiers in Ecology and the Environment 10:291-297.

Donnelly A, Caffarra A, O’Neill BF. 2011. A review of climate-driven mismatches between interdependent phenophases in terrestrial and aquatic ecosystems. International Journal of Biometeorology 55:805-817.

Ellwood ER, Primack RB, Talmadge ML. 2010. Effects of climate change on spring arrival times of birds in Thoreau's Concord from 1851 to 2007. The Condor 112:754-762.

Enquist C, Kellermann J, Gerst K, Miller-Rushing A. 2014. Phenology research for natural resource management in the United States. International Journal of Biometeorology 58:579-589. 
Everill PH, Primack RB, Ellwood ER, Melaas EK. 2014. Determining past leaf-out times of New England's deciduous forests from herbarium specimens. American Journal of Botany 101:1293-1300.

Gaira K, Uppeandra D, Belwal O. 2011. Potential of herbarium records to sequence phenological pattern: a case study of Aconitum heterophyllum in the Himalayas. Biodiversity and Conservation 20:2201-2210.

Guzmán JL, Arroyo B. 2015. Predicting winter abundance of woodcock Scolopax rusticola using weather data: implications for hunting management. European Journal of Wildlife Research 61:467-474.

Haggerty BP, Mazer SJ. 2008. The Phenology Handbook." UCSB Phenology Stewardship Program (2008): 1-21.

Haywood BK. 2014. A "sense of place" in public participation in scientific research. Science Education 98:64-83.

Hoffberg SL, Mauricio R. 2016. The persistence of invasive populations of kudzu near the northern periphery of its range in New York City determined from historical data 1, 2." The Journal of the Torrey Botanical Society 143:437-442.

Jackson M. 1966. Effects of microclimate on spring flowering phenology. Ecology 47:407-415.

Kharouba H, Paquette S, Kerr J, Vellend M. 2014. Predicting the sensitivity of butterfly phenology to temperature over the past century. Global Change Biology 20:504-514.

Lavoie C. 2013. Biological collections in an ever changing world: Herbaria as tools for biogeographical and environmental studies. Perspectives in Plant Ecology, Evolution and Systematics 15:68-76.

Lawrence A. 2009. The first cuckoo in winter: phenology, recording, credibility and meaning in Britain. Global Environmental Change 19:173-179.

McDermott ME, DeGroote LW. 2016. Long-term climate impacts on breeding bird phenology in Pennsylvania, USA. Global Change Biology 22:3304-3319. 
Meymaris K, Henderson S, Alaback P, Havens K. 2008. Project budburst: Citizen science for all seasons. AGU Fall Meeting Abstracts 1:0614.

Miller-Rushing AJ, Inouye D, Primack RB. 2008. How well do first flowering dates measure plant responses to climate change? The effects of population size and sampling frequency. Journal of Ecology 96:1289-1296.

Miller-Rushing AJ, Høye TT, Inouye DW, Post E. 2010. The effects of phenological mismatches on demography. Philosophical Transactions of the Royal Society of London B: Biological Sciences 365:3177-3186.

Miller-Rushing AJ, Primack, RB, Primack D, Mukunda S. 2006. Photographs and herbarium specimens as tools to document phenological changes in response to global warming. American Journal of Botany 93:1667-1674.

Miller-Rushing AJ, Primack RB. 2008. Global warming and flowering times in Thoreau's Concord: a community perspective. Ecology 89:332-341.

Morellato LPC, et al. 2016. Linking plant phenology to conservation biology. Biological Conservation 195:60-72.

Parmesan C. 2007. Influences of species, latitudes and methodologies on estimates of phenological response to global warming. Global Change Biology 13:1860-1872.

Polgar CA, Primack RB. 2013. Leaf out phenology in temperate forests. Biodiversity Science 21:111-116.

Posledovich D, Toftegaard T, Wiklund C, Ehrlén J, Gotthard K. 2015. The developmental race between maturing host plants and their butterfly herbivore-the influence of phenological matching and temperature. Journal of Animal Ecology 84:1690-1699.

Prather LA, Alvarez-Fuentes O, Mayfield MH, Ferguson CJ. 2004. The decline of plant collecting in the United States: a threat to the infrastructure of biodiversity studies. Systematic Botany 29:15-28. 
Primack D, Imbres C, Primack R, Miller-Rushing A, and Del Tredici P. 2004. Herbarium specimens demonstrate earlier flowering times in response to warming in Boston. American Journal of Botany 91: 1260-1264.

Primack RB, Miller-Rushing AJ. 2012. Uncovering, collecting, and analyzing records to investigate the ecological impacts of climate change: a template from Thoreau's Concord. BioScience 62:170-181.

Project BudBurst. 2017. Project BudBurst: An online database of plant phenological observations. Project BudBurst, Boulder, Colorado. Available: http://www.budburst.org; Community Attribution: http://www.budburst.org/results_attribution; Accessed: March 3, 2017.

Root TL, Price JT, Hall KR, Schneider SH, Rosenzweig C, Pounds JA. 2003. Fingerprints of global warming on wild animals and plants. Nature 421:57-60.

Robinson RA, et al. 2009. Travelling through a warming world: climate change and migratory species. Endangered Species Research 7:87-99.

Rosemartin AH, Crimmins TM, Enquist CAF, Gerst KL, Kellermann JL, Posthumus EE, Denny EG, Guertin P, Marsh L, Weltzin JF. 2014. Organizing phenological data resources to inform natural resource conservation. Biological Conservation 173:90-97.

Sullivan BL, Wood CL, Iliff MJ, Bonney RE, Fink D, Kelling S. 2009. eBird: A citizen-based bird observation network in the biological sciences. Biological Conservation 142:22822292.

Travers SE, Marquardt B, Zerr NJ, Finch JB, Boche MJ, Wilk R, Burdick SC. 2015. Climate change and shifting arrival date of migratory birds over a century in the northern Great Plains. The Wilson Journal of Ornithology 127:43-51.

van Vliet, AJH, et al. 2003. The European phenology network. International Journal of Biometeorology 47:202-212.

Vellend M, Brown CD, Kharouba HM, McCune JL, Myers-Smith IH. 2013. Historical ecology: using unconventional data sources to test for effects of global environmental change. American Journal of Botany 100:1294-1305. 
Visser, ME, Both C. 2005. Shifts in phenology due to global climate change: the need for a yardstick. Proceedings of the Royal Society B: Biological Sciences 272: 2561-2569.

Weltzin JF. 2011. The USA National Phenology Network; taking the pulse of our planet (No. 2011-3023). US Geological Survey 2011: 3023

Wiggins A, Crowston K. 2011. From conservation to crowdsourcing: A typology of citizen science. System Sciences, 44th Hawaii International Conference 1-10.

Wolkovich EM, Cleland EE. 2011. The phenology of plant invasions: a community ecology perspective. Frontiers in Ecology and the Environment 9:287-294.

Xu CY, Griffin KL, Schuster WSF. 2007. Leaf phenology and seasonal variation of photosynthesis of invasive Berberis thunbergii (Japanese barberry) and two co-occurring native understory shrubs in a northeastern United States deciduous forest. Oecologia 154:11-21.

Zelt J, Courter J, Arab A, Johnson R, Droege S. 2012. Reviving a legacy citizen science project to illuminate shifts in bird phenology. International Journal of Zoology 2012:710710. 
Table 1: Data assembled in the West Virginia Climate History Project. WV refers to West Virginia, USA.

\begin{tabular}{|c|c|c|c|c|c|}
\hline Source Type & Collector & Location of record & Description & Timeframe & \# Observations \\
\hline Personal Record & Lost Hollow Families & Miller's personal records & $\begin{array}{c}\text { Personal journals with handwritten } \\
\text { entries on spring and fall phenology in } \\
\text { Hardy County, WV }\end{array}$ & 1973-1978 & 134 \\
\hline $\begin{array}{l}\text { History Center } \\
\text { Record }\end{array}$ & Earl Brooks & $\begin{array}{c}\text { West Virginia Regional History } \\
\text { Center }\end{array}$ & $\begin{array}{l}\text { Handwritten orthnological notes of } \\
\text { breeding and migration }\end{array}$ & 1890-1915 & 919 \\
\hline $\begin{array}{l}\text { Naturalist Group } \\
\text { Record }\end{array}$ & Brooks Bird Club & Brooks Bird Club records & $\begin{array}{l}\text { Printed spring bird arrival dates in the } \\
\text { club's newsletter, The Redstart }\end{array}$ & 1933-2014 & 4558 \\
\hline Personal Record & Kay Evans & $\begin{array}{c}\text { Old Hemlock, Preston County, } \\
\text { West Virginia }\end{array}$ & $\begin{array}{l}\text { Personal journals with handwritten } \\
\text { entries on spring and fall phenology }\end{array}$ & 1939-1996 & 233 \\
\hline Personal Record & George Brieding & $\begin{array}{l}\text { Mike Brieding's personal } \\
\text { records }\end{array}$ & $\begin{array}{c}\text { Typed lists of avian arrival dates } \\
\text { throughout WV }\end{array}$ & 1950-2009 & 823 \\
\hline Personal Record & Edwin D. Michael & Michael's personal records & $\begin{array}{l}\text { Typed descriptions of phenology in } \\
\text { Cannan Valley, WV }\end{array}$ & $2009-2011$ & 52 \\
\hline Personal Record & John Weems & Weem's personal records & $\begin{array}{l}\text { Handwritten notes of plant phenology } \\
\text { in the Core Arboretum, Morgantown, } \\
\text { WV }\end{array}$ & 1980 & 64 \\
\hline Herbarium & Various & $\begin{array}{l}\text { Fairmont State University } \\
\text { Herbarium, Fairmont, WV }\end{array}$ & Pressed flower specimens & 1963-1981 & 11 \\
\hline Herbarium & Various & $\begin{array}{c}\text { Marshall University Herbarium, } \\
\text { Huntington, WV }\end{array}$ & Pressed flower specimens & $1928-2001$ & 186 \\
\hline Herbarium & Various & $\begin{array}{l}\text { University of Charleston } \\
\text { Herbarium, Charleston, WV }\end{array}$ & Pressed flower specimens & 1968 & 1 \\
\hline Herbarium & Various & $\begin{array}{c}\text { West Virginia University } \\
\text { Herbarium, Morgantown, WV }\end{array}$ & Pressed flower specimens & 1890-2013 & 125 \\
\hline Herbarium & Various & $\begin{array}{c}\text { George B. Rossbach Herbarium, } \\
\text { Buckhannon, WV }\end{array}$ & Pressed flower specimens & 1929-1999 & 37 \\
\hline Herbarium & Various & $\begin{array}{l}\text { Carnegie Museum of Natural } \\
\text { History, Pittsburgh, PA }\end{array}$ & Pressed flower specimens & 1930-1988 & 17 \\
\hline Herbarium & Andrew Walker & Old Fields, WV & Pressed flower specimens & 2013 & 2 \\
\hline Personal Record & David Smaldone & Morgantown, WV & $\begin{array}{l}\text { Dated photographs of flowers in the } \\
\text { Core Arboretum, Morgantown, WV }\end{array}$ & 2005-2015 & $\begin{array}{r}41 \\
19\end{array}$ \\
\hline
\end{tabular}




\title{
CHAPTER 3
}

\section{Changes in Flowering Phenology Over 125 Years in the Central Appalachians}

Lori Petrauski ${ }^{2,5}$, Sheldon Owen ${ }^{3}$, George Constantz ${ }^{4}$, and James T. Anderson ${ }^{2}$

\author{
${ }^{1}$ Manuscript received___ ; revision accepted
}

${ }^{2}$ School of Natural Resources, West Virginia University, Morgantown, WV 26506

${ }^{3}$ West Virginia University Extension Service, Morgantown, WV 26506

${ }^{4} 351$ N. Back Creek Rd., High View, WV 26808

${ }^{5}$ Author for correspondence

Keywords: blooming phenology; herbarium specimens; climate change; historical phenology; long-term dataset; spring phenology; West Virginia 


\section{Written in the style of: American Journal of Botany}

\section{ABSTRACT}

Spring ephemerals in the Central Appalachians are a key component of deciduous forest communities and can be indicators of shifting phenology due to climate changes in this ecosystem. The objectives of this study were to determine if there have been any changes in date of flowering for the Cutleaf Toothwort (Cardamine concatenata) and Yellow Trout Lily (Erythronium americanum) in West Virginia over the last 125 years; determine which climatic factors affect the blooming date of these perennial, spring ephemeral wildflowers; and evaluate the effect of elevation on changing blooming dates using herbarium specimens and photographs. Both species are widespread throughout the woodlands of eastern North America. Both species have significantly advanced their spring flowering over the last century $(\bar{x}=1.01$ days/decade $)$. Spring temperature was the strongest predictor of blooming date $\left(2.91\right.$ and 3.57 days earlier $/ 1^{\circ} \mathrm{C}$ increase in spring temperature, respectively). Flowers at $<500 \mathrm{~m}$ elevation bloomed earlier and demonstrated a stronger shift in flowering date over time than flowers at $>1000 \mathrm{~m}$ elevations. Lower elevations, higher spring and winter temperatures, and low amounts of precipitation were associated with earlier spring flowering. This research demonstrates the plasticity of phenological response to a variety of climatic variables, the usefulness of using herbarium specimens to reconstruct flowering dates over a topographically variable area, and the contrasting effects of climate change on high elevation regions of West Virginia.

\section{INTRODUCTION}


Climate affects the phenology of plants and animals, and changes in climate pose possible risks for phenological mismatches and shifts in vegetative communities (Memmott et al., 2007; Crimmins et al., 2008) if species cannot shift their distributions in synchrony with the changing climate (Ash et al., 2016). Flowering of herbaceous plants has been heavily studied due to the sensitivity of this phenophase to changes in climate (Gezon et al., 2016) and the fitness insights gained by studying the reproductive phase of plant life (Inouye, 2008). Flowering phenology can be influenced by a number of abiotic factors, including increasing spring temperatures (Primack et al., 2004)(especially in the months before flowering (Miller-Rushing and Primack, 2008)), spring precipitation (Matthews and Mazer, 2016), elevation (Crimmins et al., 2011; Čufar et al., 2012), and snowmelt (Inouye, 2008; Livensperger et al., 2016).

Geographic location, including elevation, is a strong contributing factor in the sensitivity of plant phenology (Matthews and Mazer, 2016), due to its association with microclimates, which can influence temperature or the risk of frost damage (Inouye, 2008). Geographic location also includes latitude, which can give insight into larger patterns of phenology (McKinney et al., 2012). For example, the phenology of species in higher latitudes in the northern hemisphere and lower latitudes in the southern hemisphere is more strongly affected by changes in climate than latitudes closer to the equator (Guyon et al., 2011). Elevation has an effect on the strength of phenology shifts in horse-chestnut trees (Aesculus hippocastanum) (Defila and Clot, 2001), and changes in climate affect phenology to a greater degree in higher elevations than lower elevations in Slovakia (Čufar et al., 2012). In the Himalayas, flowers were found to bloom an average of 26 days earlier per 1,000 $\mathrm{m}$ decrease in elevation (Gaira et al., 2011). Due to a warming climate, plants are able to expand their range and grow at higher elevations (Lenoir et al., 2008), which can affect the way these species respond to changes in climate. However, there 
can be confounding factors involved with shifting ranges. For example, Crimmins et al. (2011) found that plants in California shifted to lower elevations despite increases in temperature, due to decreased water availability in higher elevations. Therefore, it is important to examine regional climate while studying elevation as a factor of phenological shifts.

Multiple studies have shown shifts of flowering times, ranging from an average of 7 days earlier since the 1850s in Concord, Massachusetts (Miller-Rushing and Primack, 2008) to an average of 2.4 days earlier since the 1970s in Washington, D.C. (Abu-Asab et al., 2001). The strongest predictor of spring flowering phenology has been temperature (Jackson, 1966; Beaubien and Freeland, 2000; Primack et al., 2004; Miller-Rushing and Primack, 2008), which covaries with other environmental factors such as snowmelt (Inouye 2008) and elevation (Gaira et al., 2011).

Spring ephemeral wildflowers, especially sensitive to changes in climate, serve as good indicators of ecosystem response to climate change (Fitter et al., 1995). For example, spring ephemerals emerge shortly after snowmelt (Lapointe 2001), and earlier snowmelt has been linked to earlier flowering (Lambert et al., 2010). Winter temperatures and precipitation (Matthews and Mazer, 2016) have also been used to analyze flowering phenology. Warmer winter temperatures have been linked to earlier flowering dates (Beaubien and Freeland, 2000; Miller-Rushing and Primack, 2008) and increased precipitation has been associated with later flowering (Matthews and Mazer, 2015).

Benefits of earlier spring blooming could include high levels of light and moisture and less interspecific competition for pollinators (Forrest and Thomson, 2010). However, there may also be consequences associated with earlier flowering, such as frost damage leading to decreased reproductive fitness (Gezon et al., 2016). Past studies found that flowering times 
respond to increases in spring temperatures by advancing their date of flowering by 3.07 days (Miller-Rushing and Primack, 2008), 3.39 days (Park and Schwartz, 2015), 3.6 days (Primack et al., 2004), and 6 days (Robbirt et al., 2011) per $1{ }^{\circ} \mathrm{C}$ increase in spring temperature.

Developing predictive models of future phenological changes is important for managing climate-sensitive species (Gullett et al., 2013, Stevens et al., 2001). Based on the past studies cited herein, advanced spring flowering was successfully predicted during the unusually warm years of 2010 and 2012 in the eastern United States (Ellwood et al., 2013).

Most studies of flowering phenology are constrained by a lack of long-term historical data (Primack et al., 2004; Robbirt et al., 2011). This is why herbarium specimens and photographs have been explored as a way to reconstruct historical phenology (Lavoie and Lachance, 2006; Miller-Rushing et al., 2006; Gaira et al., 2011; Calinger et al., 2013; Everill et al., 2014). However, there are several issues associated with using herbarium specimens to understand phenology. Because the timing of phenophases is highly related to climate, and climatic conditions vary over sampling areas, it is difficult to compare the phenophases of specimens collected over large geographic areas (Lavoie and Lachance 2006). In addition to climatic differences, there is also uncertainty in determining exact full-flowering dates. Depending on the species, the time when an individual plant could be considered "full flowering" could range over several weeks, which could decrease the reliability of the data (Miller-Rushing et al., 2006). Despite these issues, it has been determined that herbarium specimens alone can successfully show flowering response to changing climate (Miller-Rushing et al., 2006; Robbirt et al., 2011).

The three objectives of this study were to (1) determine if there have been changes in date of flowering for two species of spring ephemerals in West Virginia over the last 125 years, (2) 
evaluate which climatic and non-climatic factors affect their blooming dates, and (3) evaluate the effect of elevation on changing blooming dates. It is important to study the factors that shift phenology because any phenophases that are altered can disrupt species interactions. We predicted that spring ephemerals have shifted their flowering dates over the last century in response to changes in climate, especially increased spring temperature, and that flowers at higher elevations would flower later than flowers at low elevations.

\section{MATERIALS AND METHODS}

Study species - Cutleaf Toothwort Cardamine concatenata (Brassicacae) and Yellow Trout Lily Erythronium americanum (Liliaceae) are both common spring wildflowers in eastern North America (Strausbaugh and Core, 1978). Their short blooming-window (one to two weeks) makes them good candidates for phenology research (Shetler and Wiser, 1987; Lapointe 2001). Both species are native perennial herbs that grow in moist bottomland and deciduous forests. Spring ephemerals are among the first plants to flower in the spring. The specific phenophase used for this study was "open flowers," which is described as at least half of the flowers on a plant in bloom (USA-NPN, 2012) and is easily observed in herbarium specimens.

Given that desynchronized phenologies are common drivers of phenological studies, exploring species interactions is an important step in understanding the future of these relationships. Pieris virginiensis (the West Virginia white butterfly) depends on early flowering plants such as $C$. concatenata for food and oviposition substrate. The phenology of this interaction is important for this declining butterfly. For example, early senescence of Cardamine diphylla, the other common host of the West Virginia White, decreases the success of Pieris virginiensis larva (Shuey and Peacock 1989). Butterfly species shift their emergence phenology in relation to temperature (Kharouba et al., 2014), but their response to changes in climate 
depends on their larval host species (Posledovich et al., 2015). Given that butterflies have shifted their phenologies three times more than spring plants in recent years (Parmesan, 2007), understanding flowering patterns in relation to climate change is important for the conservation of Pieris virginiensis (Davis and Cipollini, 2014).

Observations - We used herbarium specimens and dated photographs to identify locations and flowering dates for C. concatinata and E. americanum in West Virginia. Herbarium specimens or photographs that showed at least half of the flowers open on a plant were scored as peak-flowering (Primack et al., 2004; Primack and Miller-Rushing, 2012). Specimens were processed at 6 public herbariums, including 5 in West Virginia and 1 in Pennsylvania, and the personal herbarium of a West Virginian citizen (Table 1). To obtain elevation data and accurate climatic data, locations of observations were mapped using ArcGIS Version 10.3 using the location descriptions on the herbarium specimens. A West Virginia citizen contributed 11 dated photographs with known locations (2005-2015), which were added to the herbarium dataset to supplement the recent observations. Each usable herbarium specimen and photograph included date and location. Overall, the observations gained from these specimens reflect an average flowering date because each specimen is not necessarily a first or last flowering observation. By using average flowering dates of species with short blooming windows, our conclusions will more accurately represent the shifts and changing phenology of these species as compared to first flowering dates (CaraDonna et al., 2014).

Climate - Climate data at 13 stations in West Virginia were recorded by the US Historical Climatology Network (Williams et al., 2007) since 1890. A series of estimation maps was made for each decade (12 decades, 1890-2014) using the Radial Basis Function interpolation method in ArcGIS Version 10.3. These decadal interpolations were used to 
estimate average decadal yearly temperature, spring and winter temperatures, and spring precipitation for each flowering observation. Radial basis functions create surfaces of estimated measurements based on the degree of smoothing from measured points, resulting in an exact interpolation, which qualifies it as a suitable method for determining unknown atmospheric values based on known neighboring measurements (Apaydin et al., 2004; Ashiq et al., 2010; Benghanem and Mellit, 2010).

Analyses -The wildflowers dataset included day of the year (Julian calendar), year, elevation, average decadal spring temperature, average decadal spring precipitation, average decadal winter temperature, average decadal yearly temperature, and species. All variables were normally distributed except elevation, which was $\log$ transformed. Correlation and regression were used to test for collinearity of the variables. Yearly temperature was highly correlated with spring temperature $(r=0.86)$ and with winter temperature $(r=0.85)$, and therefore was not used in analyses (Miller-Rushing and Inouye, 2009). Significance was inferred at alpha level 0.05.

To test for changes in flowering date, the dates of flowering for each species were regressed against year. A Welch's t-test, which is robust to unequal variances and sample sizes (Ruxton, 2006), was used to determine if there was a difference between historical and current flowering dates. Historical flowering dates were considered to be before 1970 and current dates were considered the years 1970 and after, when global surface temperatures began to steadily increase (IPCC, 2014).

Observations were divided into several elevation categories (low: under 500 m, mid: 500 $-1000 \mathrm{~m}$, high: above $1000 \mathrm{~m}$ ) and the day of flowering was regressed against year for each category to compare the difference in magnitude of phenology shifts as a function of elevation. A 
one-way Analysis of Variance (ANOVA) was used to test for differences in flowering date among the elevation categories.

\section{RESULTS}

Changes in climate - Between 1970 and 2014, average spring temperatures (March April) in West Virginia increased 10 times as much as they did between 1880 and 1969, and spring temperatures between 1970 and $2014\left(\bar{x}=8.52^{\circ} \mathrm{C}, \mathrm{SE}=0.18\right)$ were significantly higher than between 1880 and $1969\left(\bar{x}=8.08{ }^{\circ} \mathrm{C}, \mathrm{SE}=0.16\right)\left(t_{103}=-1.77, P=0.03\right)$. Over the 125 year study period, the average climate variables have mostly remained constant when analyzed over the entire state (Fig. 1). Spring precipitation, spring temperature, and winter temperature have only increased slightly (precipitation increasing $0.030 \mathrm{~cm} /$ decade; spring temperature increasing $0.055^{\circ} \mathrm{C} / \mathrm{decade}$; winter temperature increasing $\left.0.003{ }^{\circ} \mathrm{C} / \mathrm{decade}\right)$ since 1890 . However, variation in temperature and precipitation exists within West Virginia and change over time is evident in some parts of the state more than others for spring temperature (Fig. 2), winter temperature (Fig. 3), and spring precipitation (Fig. 4). For example, spring and winter temperatures have especially increased in the Eastern Panhandle region of West Virginia as compared to the rest of the state, and precipitation has increased throughout the state.

Changes in flowering phenology - Overall, there were 338 observations of flowering, including 170 for C. concatenata and 168 for E. americanum. There were 16 observations from 1890 - 1929, 99 from 1930 - 1959, 140 from 1960 - 1989, and 83 from 1990 - 2015. Across historic and contemporary dates, the flowering dates were significantly different $\left(t_{336}=-3.47, P\right.$ $<0.001)$ between $C$. concatenata $(\overline{\times} \pm \mathrm{SD}=$ April $12 \pm 12.3$ days, $\mathrm{SE}=0.946)$ and $E$. americanum, $(\overline{\mathrm{x}} \pm \mathrm{SD}=$ April $16 \pm 9.7$ days, $\mathrm{SE}=0.752)$, and therefore analyzed separately. 
Normality was confirmed for flowering dates of $C$. concatenata $(W=0.987, P=0.135)$ and $E$. americanum $(W=0.997, P=0.981)$ using Shapiro-Wilk tests. $C$. concatenata and $E$. americanum have both significantly advanced their spring flowering over the last century (Fig. 5). C. concatenata $\left(F_{1,168}=5.76, P=0.017\right)$ has flowered 0.87 days earlier each decade, and $E$. americanum $\left(F_{1,166}=14.82, P<0.001\right)$ has flowered 1.15 days earlier every decade. For both species, there was a significant difference between historical $(\bar{x} \pm \mathrm{SD}=$ April $17 \pm 12.1$ days, SE $=1.004)$ flowering dates and current $(\overline{\mathrm{x}} \pm \mathrm{SD}=$ April $11 \pm 10.0$ days, $\mathrm{SE}=0.722)$ flowering dates based on Welch's t-tests. $C$. concatenata flowered significantly earlier $\left(t_{155}=3.07, P=\right.$ $0.002)$ in recent years $(\bar{x} \pm \mathrm{SD}=$ April $9 \pm 11.7$ days, $\mathrm{SE}=1.20)$ as compared to pre-1970 $(\bar{x} \pm$ $\mathrm{SD}=$ April $15 \pm 12.4$ days, $\mathrm{SE}=1.43)$, and $E$. americanum also significantly advanced $\left(t_{110}=\right.$ $3.82, P<0.001)$ its current flowering $(\bar{x} \pm \mathrm{SD}=$ April $14 \pm 7.5$ days, $\mathrm{SE}=0.75)$ as compared to historical records $(\bar{x} \pm \mathrm{SD}=$ April $20 \pm 11.4$ days, $\mathrm{SE}=1.36)$. Normality was confirmed using a Shapiro-Wilk test (C. concatenata: historical: $W=0.98, P=0.41$, current: $W=0.99, P=0.74 ; E$. americanum: historical: $W=0.96, P=0.057$, current: $W=0.98, P=0.26$ ).

Climate variables and elevation had differing effects on the date of flowering for each species, as determined using simple linear regressions. Given that elevation was log transformed, for every $277.5 \mathrm{~m}$ (10\% of total elevation range) increase in elevation, C. concatenata flowered 0.5 days later $(\mathrm{SE}=1.81)\left(F_{1,168}=8.55, P=0.004\right)$ and $E$. americanum flowered 0.72 days later $(\mathrm{SE}=1.34)\left(F_{1,166}=29.06, P<0.001\right)$ for every $124.1 \mathrm{~m}$ increase in elevation. In other terms, for every $1000 \mathrm{~m}$ increase in elevation, $C$. concatenata flowered 1.80 days later and $E$. americanum flowered 5.8 days later. $C$. concatenata flowered 2.91 days earlier $(\mathrm{SE}=0.82)$ $\left(F_{1,168}=12.51, P<0.001\right)$ and $E$. americanum flowered 3.57 days earlier $(\mathrm{SE}=0.63)\left(F_{1,166}=\right.$ $31.86, P<0.001$ ) for each $1{ }^{\circ} \mathrm{C}$ increase in spring temperature. $C$. concatenata flowered 1.57 
days earlier $(\mathrm{SE}=0.76)\left(F_{1,168}=4.28, P=0.040\right)$ and $E$. americanum flowered 1.18 days earlier $(\mathrm{SE}=0.52)\left(F_{1,166}=5.15, P=0.024\right)$ for each $1{ }^{\circ} \mathrm{C}$ increase in winter temperature. Precipitation had no significant effect on $C$. concatenata's flowering dates, but $E$. americanum flowered 2.81 days later $(\mathrm{SE}=0.72)\left(F_{1,166}=15.34, P<0.001\right)$ for every $1 \mathrm{~cm}$ increase in precipitation.

There was a significant difference in flowering dates depending on elevation $\left(F_{1,336}=\right.$ 27.11, $P<0.001)$. Flowers at low elevations bloomed earlier $(\bar{x} \pm \mathrm{SD}=$ April $13 \pm 10.8$ days, $\mathrm{SE}$ $=0.643)$ as compared to mid elevations $(\bar{x} \pm \mathrm{SD}=$ April $17 \pm 12.2$ days, $\mathrm{SE}=1.953)$ and high

elevations $(\bar{x} \pm \mathrm{SD}=$ April $26 \pm 9.1$ days, $\mathrm{SE}=2.143)$. Flowers at low elevations demonstrated a stronger shift in flowering date over time (1.07 days earlier each decade) than flowers at mid (0.68 days earlier each decade) or high elevations (1.3 days later each decade). Normality was confirmed for low $(W=0.992, P=0.199)$, $\operatorname{mid}(W=0.978, P=0.647)$, and high $(W=0.980, P=$ 0.950) elevations using a Shapiro-Wilk test and equal variances were confirmed using a Kolmogorov-Smirnov test $(D=0.154, P=0.390)$.

\section{DISCUSSION}

Overall, the flowering of E. americanum and C. concatenata advanced over the last 125 years and the flowers are blooming earlier than they did historically. E. americanum advanced its spring flowering by an average of 6 days and was more sensitive to elevation, spring temperature, and spring precipitation than C. concatenata, which has also advanced an average of 6 days. C. concatenata was slightly more affected by warmer winter temperatures. Lower elevations, higher spring temperatures, higher winter temperatures, and low amounts of precipitation were associated with earlier spring flowering overall. Spring precipitation only affected the flowering of E. americanum, an effect supported by previous research (Matthews 
and Mazer, 2016). Years with higher spring precipitation and lower spring temperatures were associated with later flowering dates.

One of the major drivers of phenological studies is the risk of phenological mismatch (Root et al., 2003), which can occur when one species advances (Kudo and Ida, 2013) or delays (Gezon et al., 2016) its phenology in relation to interacting species. For example, early-blooming spring ephemerals may incur lower reproductive success due to a difference in phenological response by their pollinators (Rafferty and Ives, 2011; Kudo and Ida, 2013). However, for Claytonia lanceolata, another spring ephemeral, the rate of pollinator visits was higher for plants that flowered early, but not so early that they were threatened by frost (Gezon et al., 2016). In this case, the spring ephemeral balanced environmental and species interaction constraints for optimal flowering date.

In general, it is thought that earlier blooming due to increased temperatures is beneficial for the plant's reproductive success (Elzinga et al., 2007) partly due to increased pollinator visits (Rafferty and Ives, 2010); however, there is some disparity in the literature depending on the pollinator. For example, in Japan, spring-ephemerals that bloomed earlier due to increasing temperatures differed in their reproductive success (seed production) based on their pollinators (Kudo et al., 2004) - the seed-set of bee-pollinated ephemerals drastically decreased, whereas fly-pollinated ephemerals experienced no change in their seed production due to the earlier blooming.

Earlier blooming caused by earlier spring onset has been linked to fewer pollinator visits (Petanidou et al., 2014) and a phenological mismatch in the emergence of pollinator bees, which resulted in decreased reproductive success for the spring ephemerals that relied on bees for pollination (Kudo and Ida, 2013). Although generalist pollinators do occur in early spring within 
temperate deciduous forest communities (Motten, 1986), C. concatenata is primarily pollinated by bees and E. americanum is pollinated by ants, so perhaps $C$. concatenata receives more severe consequences and less reproductive benefits for earlier blooming than E. americanum, which could help explain why E. americanum is advancing spring flowering more than $C$. concatenata.

Elevation had a strong effect on the flowering of these species. Flowers at $<500 \mathrm{~m}$ elevation bloomed earlier in the spring and advanced their flowering dates over time more than flowers at mid (500 m-1000 m) and high (> $1000 \mathrm{~m})$ elevations. In addition, the flowers found at $>1000 \mathrm{~m}$ in elevation have flowered later over time, which could be attributed to varying effects of climate change on high elevation areas as compared to low elevations. This suggests that wildflower communities at different elevations will be affected differently by changing climate. The high elevation areas of West Virginia also were the areas that experienced the least amount of climatic changes over the last century (Fig. 2, 3, 4), which would explain the lack of earlier flowering in high elevation species.

Our large statewide study area could harbor possible bias in imprecise geographic locations for flowering observations. Given that the location information on the herbarium specimens was not always exact, factors such as hillshade and aspect, which have been shown to explain variation in flowering phenology (Jackson, 1966) could serve as confounding variables. Nonetheless, the high number of flowering observations $(n=338)$ overcomes such a sampling bias (Primack et al., 2004).

Based on their advancing flowering dates, C. concatenata and E. americanum, are at risk for phenological mismatches, including pollinator interactions and other species that may rely on the phenophases of these flowers, such as Pieris virginiensis (the West Virginia white butterfly). 
This research demonstrates the plasticity of phenological response to a variety of climatic variables, the usefulness of using herbarium specimens to reconstruct flowering dates over a topographically variable area, and the contrasting effects of climate change on high elevation regions of West Virginia. As a key component in deciduous forest communities, spring ephemerals in West Virginia are valuable indicators of shifting phenology in this ecosystem.

\section{ACKNOWLEDGMENTS}

We thank many people who contributed observations and access to data: Carnegie Museum of Natural History, West Virginia University Herbarium, Fairmont State University Herbarium, University of Charleston Herbarium, George B. Rossbach Herbarium, Marshall University Herbarium, David Smaldone (Resource Recreation and Tourism, West Virginia University), and Andrew Walker (West Virginia University). We also thank Thomas Rodd (Friends of Blackwater) and Greg Good (Center for History of Physics, American Institute of Physics) for ideas and logistics. Funding and logistical support was provided by the U.S.

Department of Agriculture, Northeast Climate Hub, the West Virginia Humanities Council, and the West Virginia University Natural History Museum. This is manuscript number Xxxx of the West Virginia University Agriculture and Forestry Experiment Station. 


\section{LITERATURE CITED}

Abu-Asab, M., P. Peterson, S. Shetler, and S. Orli. 2001. Earlier plant flowering in spring as a response to global warming in the Washington, DC, area. Biodiversity \& Conservation 10: 597-612.

Apaydin, H., F. Sonmez, and Y. Yildirim. 2004. Spatial interpolation techniques for climate data in the GAP region in Turkey. Climate Research 28: 31-40.

Ash, J., T. Givnish, and D. Waller. 2016. Tracking lags in historical plant species' shifts in relation to regional climate change. Global Change Biology. DOI: 10.1111/gcb.13429

Ashiq, M., C. Zhao, J. Ni, and M. Akhtar. 2010. GIS-based high-resolution spatial interpolation of precipitation in mountain-plain areas of Upper Pakistan for regional climate change impact studies. Theoretical and Applied Climatology 99: 239-253.

Beaubien, E., and H. Freeland. 2000. Spring phenology trends in Alberta, Canada: links to ocean temperature. International Journal of Biometeorology 44: 53-59.

Benghanem, M., and Mellit, A. 2010. Radial basis function network-based prediction of global solar radiation data: application for sizing of a stand-alone photovoltaic system at AlMadinah, Saudi Arabia. Energy 35: 3751-3762.

Calinger, K., S. Queenborough, and P. Curtis. 2013. Herbarium specimens reveal the footprint of climate change on flowering trends across north-central North America. Ecology Letters 16: 1037-1044.

CaraDonna, P., A. Iler, and D. Inouye. 2014. Shifts in flowering phenology reshape a subalpine plant community. Proceedings of the National Academy of Sciences 111: 4916-4921.

Crimmins, S, S. Dobrowski, J. Greenberg, J. Abatzoglou, and A. Mynsberge. 2011. Changes in climatic water balance drive downhill shifts in plant species' optimum elevations. Science 331: 324-327. 
Crimmins, T., M. Crimmins, D. Bertelsen, and J. Balmat. 2008. Relationships between alpha diversity of plant species in bloom and climatic variables across an elevation gradient. International Journal of Biometeorology 52: 353-366.

Čufar, K., M. De Luis, M. Saz, Z. Črepinšek, and L. Kajfež-Bogataj. 2012. Temporal shifts in leaf phenology of beech (Fagus sylvatica) depend on elevation. Trees 26: 1091-1100.

Davis, S., and D. Cipollini. 2014. How environmental conditions and changing landscapes influence the survival and reproduction of a rare butterfly, Pieris virginiensis (Pieridae). Journal of the Lepidopterists' Society 68: 61-65.

Defila, C., and B. Clot. 2001. Phytophenological trends in Switzerland. International Journal of Biometeorology 45: 203-207.

Ellwood, E., S. Temple, R. Primack, N. Bradley, and C. Davis. 2013. Record-breaking early flowering in the eastern United States. PloS One 8: e53788.

Elzinga, J., A. Atlan, A. Biere, L. Gigord, A. Weis, and G. Bernasconi. 2007. Time after time: flowering phenology and biotic interactions. Trends in Ecology \& Evolution 22: 432439.

Everill, P., R. Primack, E. Ellwood, and E. Melaas. 2014. Determining past leaf-out times of New England's deciduous forests from herbarium specimens. American Journal of Botany 101: 1293-1300.

Fitter, A., R. Fitter, I. Harris, and M. Williamson. 1995. Relationships between first flowering date and temperature in the flora of a locality in central England. Functional Ecology 9: $55-60$.

Forrest, J., and J. Thomson. 2010. Consequences of variation in flowering time within and among individuals of Mertensia fusiformis (Boraginaceae), an early spring wildflower. American Journal of Botany 97: 38-48.

Gaira, K., D. Uppeandra, and O. Belwal. 2011. Potential of herbarium records to sequence phenological pattern: a case study of Aconitum heterophyllum in the Himalayas. Biodiversity and Conservation 20: 2201-2210. 
Gezon, Z., D. Inouye, and R. Irwin. 2016. Phenological change in a spring ephemeral: implications for pollination and plant reproduction. Global Change Biology 22: 17791793.

Gullett, P., B. Hatchwell, R. Robinson, and K. Evans. 2013. Phenological indices of avian reproduction: cryptic shifts and prediction across large spatial and temporal scales. Ecology and Evolution 3: 1864-1877.

Guyon, D., M. Guillot, Y. Vitasse, H. Cardot, O. Hagolle, S. Delzon, and J. Wigneron, 2011. Monitoring elevation variations in leaf phenology of deciduous broadleaf forests from SPOT/VEGETATION time-series. Remote Sensing of Environment 115: 615-627.

Inouye, D. 2008. Effects of climate change on phenology, frost damage, and floral abundance of montane wildflowers. Ecology 89: 353-362.

IPCC. 2014. Climate change 2014: synthesis report. Contributions of Working Groups I, II, and III to the Fourth Assessment Report of the Intergovernmental Panel on Climate Change. IPCC, Geneva, Switzerland.

Jackson, M. 1966. Effects of microclimate on spring flowering phenology. Ecology 47: 407-415.

Kharouba, H., S. Paquette, J. Kerr, and M. Vellend. 2014. Predicting the sensitivity of butterfly phenology to temperature over the past century. Global Change Biology 20: 504-514.

Kudo, G., Y. Nishikawa, T. Kasagi, and S. Kosuge, S. 2004. Does seed production of spring ephemerals decrease when spring comes early? Ecological Research 19: 255-259.

Kudo, G., and T. Ida. 2013. Early onset of spring increases the phenological mismatch between plants and pollinators. Ecology 94: 2311-2320.

Lambert, A., A. Miller-Rushing, and D. Inouye. 2010. Changes in snowmelt date and summer precipitation affect the flowering phenology of Erythronium grandiflorum (glacier lily; Liliaceae). American Journal of Botany 97: 1431-1437.

Lapointe, L. 2001. How phenology influences physiology in deciduous forest spring ephemerals. Physiologia Plantarum 113: 151-157. 
Lavoie, C., and D. Lachance. 2006. A new herbarium-based method for reconstructing the phenology of plant species across large areas. American Journal of Botany 93: 512-516.

Lenoir, J., J. Gégout, P. Marquet, P. De Ruffray, and H. Brisse. 2008. A significant upward shift in plant species optimum elevation during the 20th century. Science 320: 1768-1771.

Livensperger, C., H. Steltzer, A. Darrouzet-Nardi, P. Sullivan, M. Wallenstein, and M.

Weintraub. 2016. Earlier snowmelt and warming lead to earlier but not necessarily more plant growth. AoB Plants 8: plw021.

Matthews, E. and S. Mazer. 2016. Historical changes in flowering phenology are governed by temperaturex precipitation interactions in a widespread perennial herb in western North America. New Phytologist 210: 157-167.

McKinney, A., P. CaraDonna, D. Inouye, B. Barr, C. Bertelsen, and N. Waser. 2012. Asynchronous changes in phenology of migrating Broad-tailed Hummingbirds and their early-season nectar resources. Ecology 93: 1987-1993.

Memmott, J., P. Craze, N. Waser, and M. Price. 2007. Global warming and the disruption of plant-pollinator interactions. Ecology Letters 10: 710-717.

Miller-Rushing, A., and D. Inouye. 2009. Variation in the impact of climate change on flowering phenology and abundance: an examination of two pairs of closely related wildflower species. American Journal of Botany 96: 1821-1829.

Miller-Rushing, A., R. Primack, D. Primack, and S. Mukunda. 2006. Photographs and herbarium specimens as tools to document phenological changes in response to global warming. American Journal of Botany 93: 1667-1674.

Miller-Rushing, A., D. Inouye, and R. Primack. 2008. How well do first flowering dates measure plant responses to climate change? The effects of population size and sampling frequency. Journal of Ecology 96: 1289-1296.

Miller-Rushing, A., and R. Primack, 2008. Global warming and flowering times in Thoreau's Concord: a community perspective. Ecology 89: 332-341. 
Motten, A. 1986. Pollination ecology of the spring wildflower community of a temperate deciduous forest. Ecological Monographs 56: 21-42.

Park, I., and M. Schwartz. 2015. Long-term herbarium records reveal temperature-dependent changes in flowering phenology in the southeastern USA. International Journal of Biometeorology 59: 347-355.

Parmesan, C. 2007. Influences of species, latitudes and methodologies on estimates of phenological response to global warming. Global Change Biology 13: 1860-1872.

Petanidou, T., A. Kallimanis, S. Sgardelis, A. Mazaris, J. Pantis, and N. Waser. 2014. Variable flowering phenology and pollinator use in a community suggest future phenological mismatch. Acta Oecologica 59: 104-111.

Posledovich, D., T. Toftegaard, C. Wiklund, J. Ehrlén, and K. Gotthard. 2015. The developmental race between maturing host plants and their butterfly herbivore-the influence of phenological matching and temperature. Journal of Animal Ecology 84: $1690-1699$.

Primack, R., and A. Miller-Rushing. 2012. Uncovering, collecting, and analyzing records to investigate the ecological impacts of climate change: a template from Thoreau's Concord. BioScience 62: 170-181.

Primack, D., C. Imbres, R. Primack, A. Miller-Rushing, and P. Del Tredici. 2004. Herbarium specimens demonstrate earlier flowering times in response to warming in Boston. American Journal of Botany 91: 1260-1264.

Rafferty, N., and A. Ives. 2011. Effects of experimental shifts in flowering phenology on plantpollinator interactions. Ecology Letters 14: 69-74.

Robbirt, K., A. Davy, M. Hutchings, and D. Roberts. 2011. Validation of biological collections as a source of phenological data for use in climate change studies: a case study with the orchid Ophrys sphegodes. Journal of Ecology 99: 235-241.

Root, T., J. Price, K. Hall, S. Schneider, C. Rosenzweig, and J. Pounds. 2003. Fingerprints of global warming on wild animals and plants. Nature 421: 57-60. 
Ruxton, G. 2006. The unequal variance t-test is an underused alternative to Student's t-test and the Mann-Whitney U test. Behavioral Ecology 17: 688-690.

Shetler, S., and S. Wiser. 1987. First flowering dates for spring-blooming plants of the Washington, DC, area for the years 1970 to 1983. Proceedings of the Biological Society of Washington 100: 993-1017.

Shuey, J., and J. Peacock. 1989. Host plant exploitation by an oligophagous population of Pieris virginiensis (Lepidoptera: Pieridae). American Midland Naturalist 122: 255-261.

Stevens, M. H. Henry, and W. Carson. 2001. Phenological complementarity, species diversity, and ecosystem function. Oikos 92: 291-296.

Strausbaugh, P., and E. Core. 1978. Flora of West Virginia. Seneca Books, Grantsville, West Virginia, USA.

USA-NPN National Coordinating Office. 2012. USA-NPN Plant and Animal Phenophase Definitions. Website: https://www.usanpn.org/files/shared/files/USANPN_Phenophase_defs-report_FINAL.pdf [accessed 8 February 2017].

Williams C., M. Menne, R. Vose, and D. Easterling. 2007. United States historical climatology network monthly temperature and precipitation data. Carbon Dioxide Information Analysis Center, Oak Ridge National Laboratory, US Department of Energy, Oak Ridge, Tennessee, USA. Website: http://cdiac.ornl.gov/epubs/ndp/ushcn/ushcn.html [accessed 8 February 2017]. 
Table 1. Sources of flowering data for Cardamine concatenata and Erythronium americanum in West Virginia, USA over the last 125 years.

\begin{tabular}{cccccc}
\hline & \multicolumn{3}{c}{ Number of Records } & & \\
\cline { 2 - 4 } Source & $\begin{array}{c}\text { Cardamine } \\
\text { concatenata }\end{array}$ & $\begin{array}{c}\text { Erythronium } \\
\text { americanum }\end{array}$ & City & Dates \\
\hline \hline Fairmont State University Herbarium & 1 & 10 & Fairmont, WV & $1963-1981$ \\
Marshall University Herbarium & 72 & 61 & Huntington, WV & $1928-2001$ \\
University of Charleston Herbarium & 0 & 1 & Charleston, WV & 1968 \\
West Virginia University Herbarium & 63 & 59 & Morgantown, WV & $1890-2013$ \\
George B. Rossbach Herbarium & 17 & 20 & Buckhannon, WV & $1929-1999$ \\
Carnegie Museum of Natural History & 11 & 6 & Pittsburgh, PA & 1930-1988 \\
Personal Herbarium & 1 & 1 & Old Fields, WV & 2013 \\
Personal Photograph Collection & 5 & 6 & Morgantown, WV & 2005-2015 \\
\hline
\end{tabular}


Fig. 1. Average climate in West Virginia, USA over 125 years (1890-2014). (A) Spring temperature is average March-April temperatures, (B) spring precipitation is average MarchApril rainfall, and (C) winter temperature is average January - February temperature based on 13 United States Historical Climatology Network recording stations located in West Virginia.

A

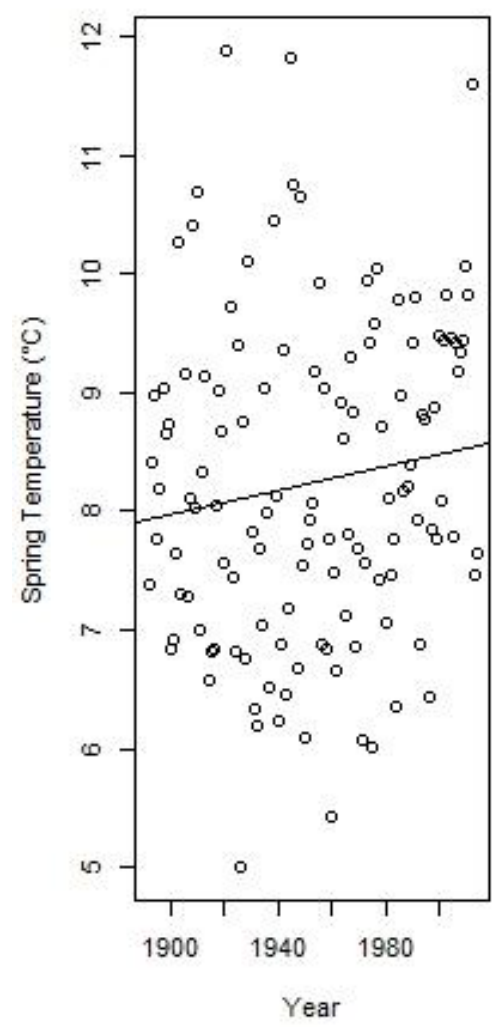

B

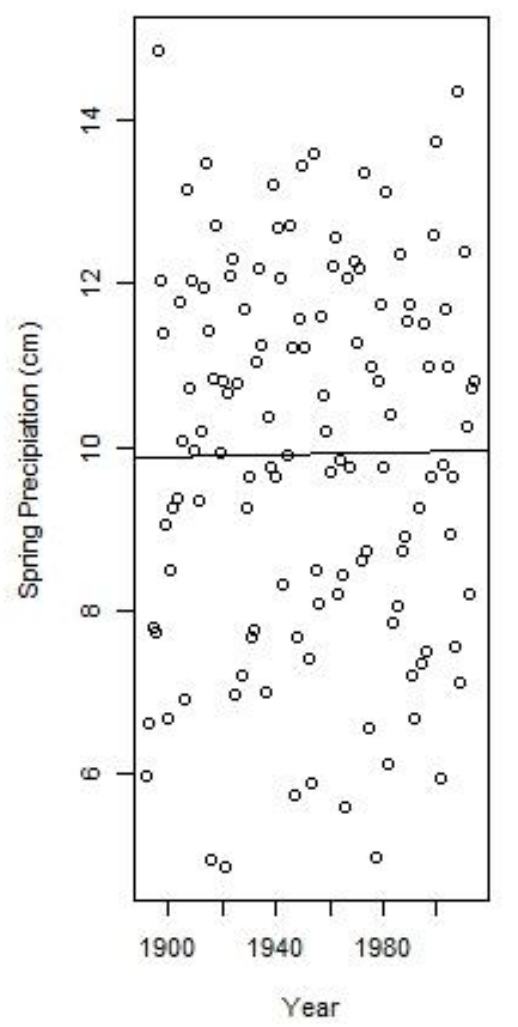

C

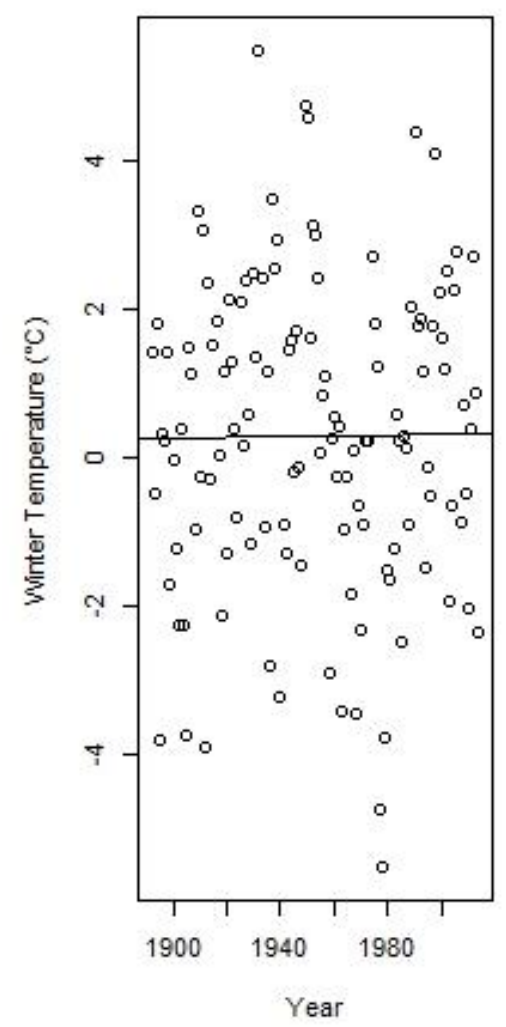


Fig. 2. Spring temperature (March - April) interpolations in West Virginia, USA from the 1890s (1890-1899) and 2000s (2000-2014). Interpolations are based on climate data from 13 United States Historical Climatology Network recording stations located in West Virginia. 


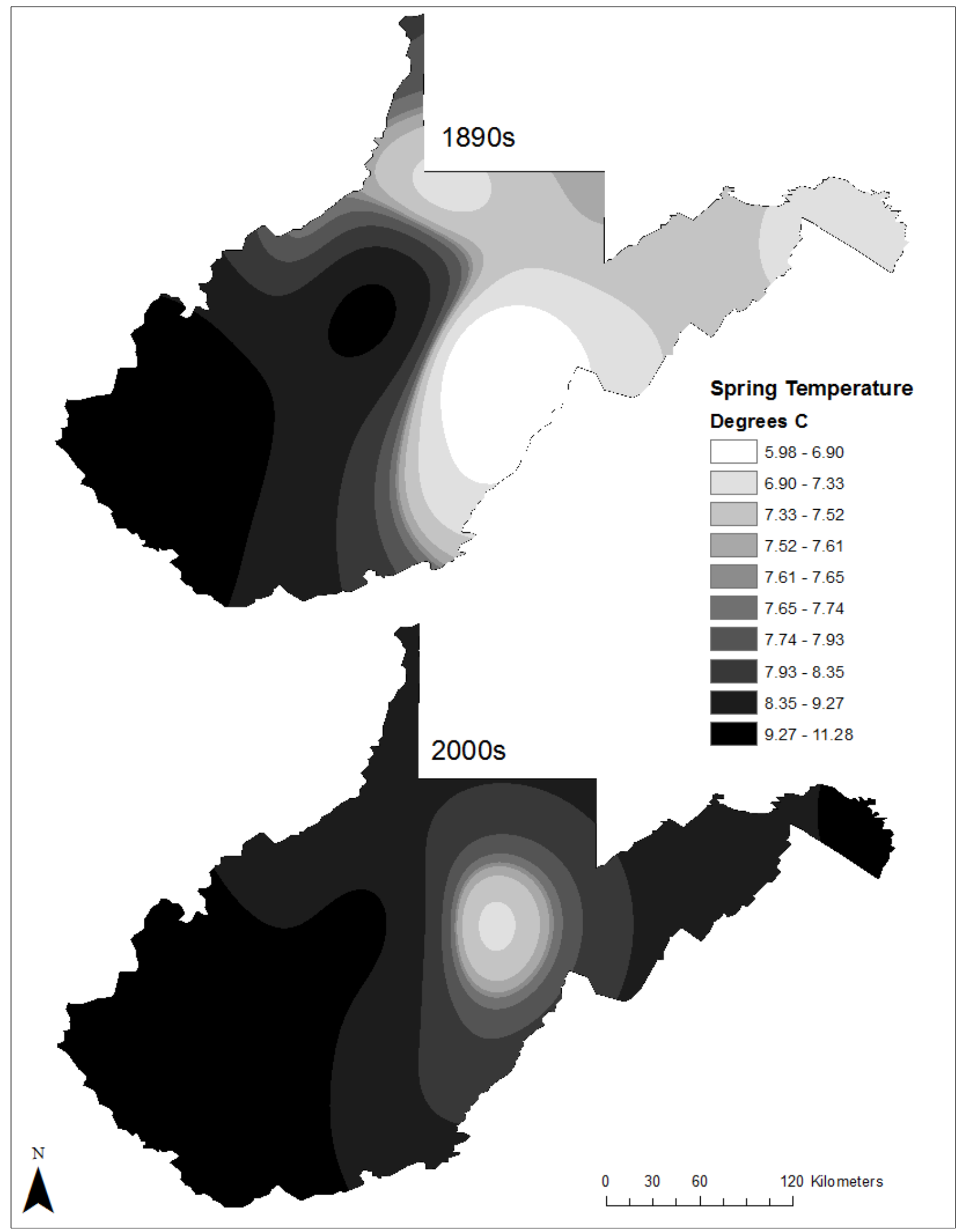

Fig. 3. Winter temperature (January - February) interpolations in West Virginia, USA from the 1890s (1890-1899) and 2000s (2000-2014). Interpolations are based on climate data from 13 United States Historical Climatology Network recording stations located in West Virginia. 


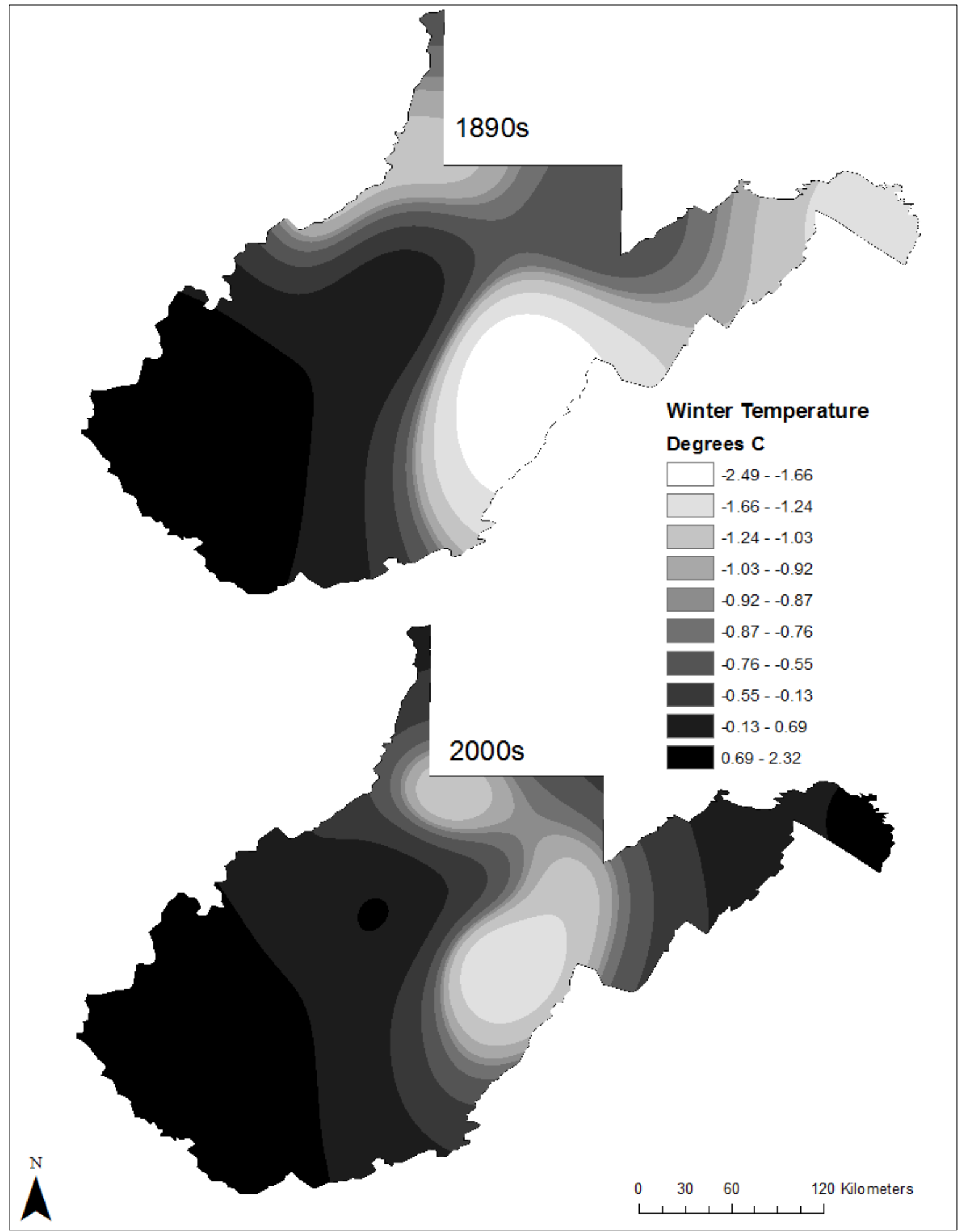

Fig. 4. Spring precipitation (March - April) interpolations in West Virginia, USA from the 1890s (1890-1899) and 2000s (2000-2014). Interpolations are based on climate data from 13 United States Historical Climatology Network recording stations West Virginia. 


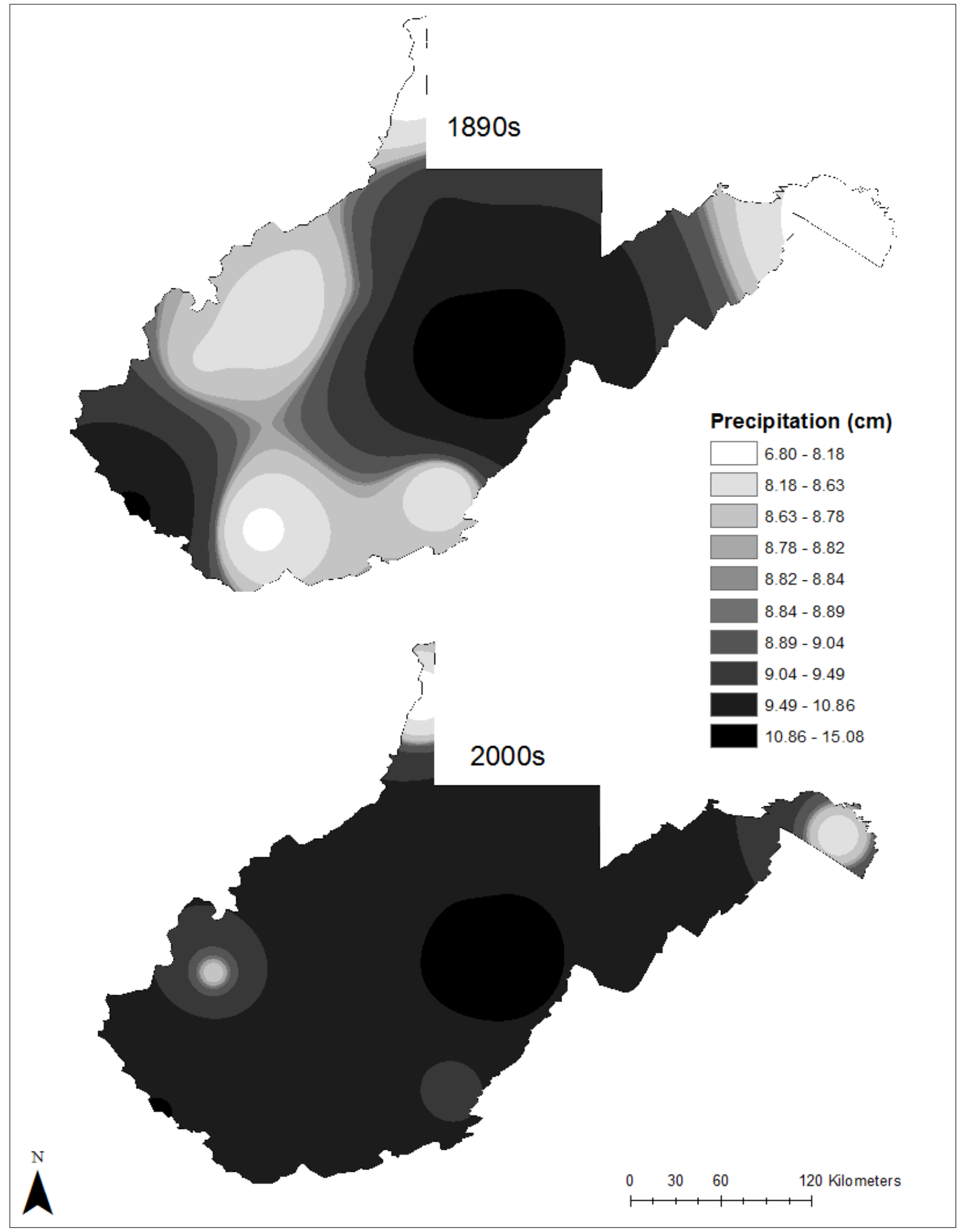

Fig. 5. Flowering dates of (A) C. concatenata and (B) E. americanum in West Virginia, USA from 1890-2015.

A 


\section{CHAPTER 4}




\title{
Changes in Avian Spring Arrival Dates of 115 Species in the Central Appalachian Over 127 Years
}

\author{
Lori Petrauski ${ }^{1}$, Sheldon Owen ${ }^{2}$, George Constantz ${ }^{3}$, and James T. Anderson ${ }^{1}$
}

${ }^{1}$ Division of Forestry and Natural Resources, West Virginia University, Morgantown, WV 26506

${ }^{2}$ West Virginia University Extension Service, Morgantown, WV 26506

${ }^{3} 351$ N. Back Creek Rd., High View WV 26808

Keywords: migration phenology, historical migration, spring arrival, long-term dataset, climate change, avian migration

Written in the style of: Global Change Biology

\begin{abstract}
Global climate change is affecting many facets of avian ecology, such as shifts in breeding phenology and patterns of migration. Migrating bird species are responding to changes
\end{abstract}


in climate by shifting their temporal patterns of spring migration; however, variation in species' responses exists based on a variety of life history traits, which exposes some species to increased risk of phenological mismatch. This study examined the spring arrival dates of 115 migrating species over a span of 127 years (1889-2015) using archival sources in West Virginia, USA, making this research unique in the length of study, the high number of species studied, and in the historical crowd-sourced observations analyzed. Data were gathered as part of the West Virginia Climate History Project, a citizen science effort to uncover long-term phenology data for the state of West Virginia by the West Virginia University Natural History Museum. Of the 115 taxa, 45 showed significant negative slopes of spring arrival dates (arriving earlier in the spring) plotted against year, whereas only 9 species showed positive slopes (arriving later in the spring), albeit non-significant. The average advance of spring arrival date for all species was 1.7 days per decade, and an advance of 2.6 days per decade in species that showed significance. Arrival dates were associated with increasing spring temperatures - for each $1{ }^{\circ} \mathrm{C}$ increase in spring temperature, arrival date advanced by 0.81 days/decade. Several life history traits were linked to species that advanced their first arrival dates, including a shorter distance migrated to reach wintering grounds, increasing populations, and foraging habitat. In conclusion, we argue that determining species with increased risk of phenological mismatch is important for future management plans, and we draw attention to shifts in arrival dates and wintering ranges, leading to a possible increase in overwintering in the mid-latitudes of North America.

\section{Introduction}

Phenological trends in plants and animals have been linked to changes in climate, including increased temperature (Butler, 2003; Mills, 2005; Vegvari et al., 2010; Kullberg et al., 
2015; McDermott \& DeGroote, 2016), varying precipitation patterns (Studds \& Marra, 2011), and more instances of climate extremes (La Sorte et al., 2016). These changes lead to increased risk of phenological mismatches (McKinney et al., 2012), decreased species success (Kerby \& Post, 2013), and ultimately decreased biodiversity (Willis et al., 2008). Phenological mismatches, or decoupled phenologies, occur during species interactions, such as predator-prey or pollinator relationships, when the changes in timing of one species' life history trait (i.e. timing of insect emergence) decrease the success of another dependent species (i.e. insectforagers) (Crick, 2004; Both et al., 2006; Miller-Rushing et al., 2008). These changes in climatic variables have been linked to many facets of avian ecology, including shifts in breeding phenology (Both \& Visser, 2001; Ahola et al., 2004; Visser and Both., 2006; McDermott \& DeGroote, 2016), patterns of migration (Butler, 2003; Cotton, 2003; Visser et al., 2005; Ellwood, 2010), and general distribution (Kullberg et al., 2015, La Sorte et al., 2016).

Migrating bird populations have been highlighted as a conservation concern (Langham $e t$ $a l ., 2015)$ based on their complex life history strategies that involve covering vast geographic areas, multiple habitat and land cover types, and a variety of climatic pressures throughout the year. Given the myriad biotic and abiotic interaction opportunities presented to avian species each year, it follows that shifts in avian phenology can be attributed to a number of environmental variables (Both \& Visser, 2001) and changes in vegetative phenology (Marra et al., 2005). Understanding which specific life history traits contribute to these shifts is important for the conservation of these species.

Shifts in spring migration have been studied using first arrival dates (FADs) (Butler, 2003; Mills, 2005) or average arrival (Ellwood et al., 2010). Comparing the arrival of one species over time can reveal patterns of spring migration. Archival records have been used to 
collect first arrival dates of migrants for temporal analyses in the past (Bradley et al., 1999; Butler, 2003; Ellwood et al., 2010; McKinney, 2012; Travers et al., 2015). Evidence exists that spring arrival is advancing due to a number of variables, including climatic factors such as increasing spring temperatures (Swanson \& Palmer, 2009), increased spring precipitation (Arab et al., 2016), the North Atlantic Oscillation (Marra et al., 2005), increased temperatures in wintering grounds (Cotton, 2003), and changes in the length of the growing season (Travers et al., 2015). Avian migrants that have advanced their spring arrival have been shown to correlate with trends of increased abundance, which demonstrates survival benefits for species with high adaptability (Newson et al., 2016). There have been efforts to examine the factors relating to avian ecology and populations that would affect the timing of spring arrival, including changes in population sizes (Moller et al., 2008), foraging habitat (Butler, 2003), distance migrated (Gill et al., 2014; Kullberg et al., 2015), and sampling effort (Miller-Rushing et al., 2008).

Population status of migratory birds has been an area of interest for birders and researchers for decades. Based on analyses of 426 species from The North American Breeding Bird Survey (1966 - 2011), 57\% of bird species are experiencing population declines. Of the 133 Neotropical migrants included in the study, 60\% demonstrated negative trend estimates (Sauer $e t$ al., 2013), and these population declines were first noted several decades ago (Robbins et al., 1989). These population reductions are attributed to deforestation and fragmentation in the tropics (Shaw et al., 2013), which reduces habitat for Neotropical migrants. These changes in population sizes may affect the patterns detected by studying spring migration in multiple ways. European migratory bird species with declining breeding populations responded the least to climate change (Møller et al., 2008), which could be demonstrated by a minimal change in FAD over time. However, species that show declining populations over the timeline of study could be 
deceptively arriving later due to decreased migration cohort sizes, leading to an underestimated change in FAD in these species (Miller-Rushing et al., 2008). A similar phenomenon occurs in species with increasing populations - a bird's spring arrival date is likely to be detected earlier with increased population sizes (Tryjanowski \& Sparks, 2001). Therefore, population status is an important factor to account for when studying historical migration patterns.

The distance traveled between the wintering grounds and breeding grounds differs among avian species, ranging from 35,000 km for the Arctic Tern, Sterna paradisaea, that flies between the Arctic and Antarctic, to less than 1,000 km for some populations of the Dark-eyed Junco, Junco hyemalis, that migrate only to higher elevations for breeding. The cues associated with the start of migration differ depending on the distance migrated each year. Short-distance migrants that winter close to the breeding grounds are more inclined to follow changes in day length (Marra et al., 2005) and seasonal climatic shifts (Miller-Rushing et al., 2008), whereas species near the equator would not be affected by photoperiod or weather at the breeding grounds (Jonzén et al., 2006). Long-distance migrants rely on circannual rhythms to cue their migration (Gwinner 1996; Both \& Visser, 2001). These different strategies of migration could impact the flexibility of species to respond to changes in their environment. Advancement of spring arrival has been shown to be greater in short-distance migrants than long-distance migrants (Butler, 2003; Vegvari et al., 2010; Sauer, 2013; Bitterlin \& Buskirk, 2014; Kullberg et al., 2015), with few exceptions (Jonzen et al., 2006). Categorizing species by the distance migrated each year could bring insight into understanding the factors affecting avian migration.

Another factor that could contribute to changing population sizes and affect migration patterns is foraging habitat. Habitat destruction is a main cause of declining avian populations (Gilroy et al., 2016), so it is possible that species occupying certain habitats have experienced 
increased pressure from habitat loss, which could affect their ability to respond to environmental cues. Habitat has been shown to both affect changes in migration time (Butler, 2003) and have no significant effect (Miller-Rushing et al., 2008; Vegvari et al., 2010), which supports the need for more research into this topic. Foraging habitat could also offer some insight into species interactions that could affect spring arrival. For example, species that rely on insects as their main foraging item could suffer an increased risk of phenological mismatch if the insect populations are responding differently to changes in local climate (Robinet \& Roques, 2010), or may be more responsive to changes in climate because they depend on the emergence of their prey (Bitterlin \& Buskirk, 2014). Avian migrants with a more generalized diet advance their FADs more than species with specialized diets (Vegvari et al., 2010). If changes in FADs differ among niches, then increased conservation effort could be identified for certain habitats.

In this study, FADs of 115 species were analyzed over a span of 127 years $(1889-2015)$ to determine any shifts over time. Data were gathered as part of the West Virginia Climate History Project, a crowd-source effort to uncover long-term phenology data for the state of West Virginia by the West Virginia University Natural History Museum. Historical FADs were considered the observations before 1970, when global surface temperatures began to steadily increase (IPCC, 2014). Species also were analyzed by distance migrated, habitat, and population status in order to gain a better understanding of the complicated ecological factors of avian life history and how they relate to spring arrival. We predicted an overall advancement of spring arrival dates across species, with variation depending on life history variables. Short-distance migrants were predicted to have advanced their first arrival dates more than long-distance migrants, species with increasing populations to have advanced more than species with decreasing populations, and species associated with threatened habitats or insectivorous diets to 
advance their spring arrival less than species occupying more stable habitats or diets of fish or other animals. Observations from higher elevations were predicted to be later in the spring and years with warmer spring temperatures were predicted to have earlier first arrival observations.

\section{Materials and Methods}

Study area

West Virginia is a heavily forested, mountainous state located in the Appalachian region of the United States. Temperature, elevation, and precipitation differ considerably throughout the state. The average statewide yearly temperature is $6-17\left({ }^{\circ} \mathrm{C}\right)$, where the lower southern regions are warmer than the mountainous regions. The average elevation is $457 \mathrm{~m}$ with the highest point (Spruce Knob) at 1,482 m and the lowest point (Harper's Ferry) at $149 \mathrm{~m}$ above sea level. Annual precipitation ranges between 81 and $132 \mathrm{~cm}$ statewide. West Virginia is $79 \%$ forested and the forests are $94 \%$ deciduous hardwoods. Oak-hickory forest type covers $74 \%$ of West Virginia forestlands followed by northern hardwood forest type (18\%) (Morin et al., 2016). West Virginia is partially composed of hemlock forests, and boreal and red spruce forests in high elevations. The rich biodiversity of West Virginia offers itself well to studying phenology.

\section{Historical observations}

Observations of first arrival dates were gathered from multiple sources: Earl Brooks and his colleagues (1890 - 1916), members of the Brooks Bird Club (1929 - 2008), George Brieding (1955 - 2006), and members of the online birding community eBird (2003 - 2015) in the state of West Virginia (Table 1). The FADs for spring migrants were taken from the personal records of Earl Brooks and George Brieding, from the publication of the Brooks Bird Club, The Redstart, and from eBird's "First of the Year" spreadsheet. Daily temperatures were obtained through the 
US Historical Climatology Network from 13 climate stations in West Virginia between 1879 2015 (Williams et al., 2007) (Fig. 1).

It was assumed that the date of spring arrival was closely associated with the first of the year sighting for each species. Earl Brooks was a student at West Virginia University, class of 1897, who collected ornithological data, including first arrival dates, between 1889 and 1916 . These observations eventually were compiled into Forty Common Birds of West Virginia (Brooks, 1915), a book that is considered a pioneering classic in the field of ornithology, along with several publications between 1900 and 1916. The handwritten lists collected by Brooks and his coworkers were found in notebooks held at the West Virginia Regional History Center in Morgantown, West Virginia, USA. All of the observations were in Clay, Marion, Lewis, Kanawha, Mineral, Upshur, and Wood counties (Fig. 1).

The Brooks Bird Club is a nature club that has operated in West Virginia since 1932. Starting in 1933, the Brooks Bird Club released a newsletter to the club's members called The Redstart. This newsletter, which is still in operation today, includes articles about birds, book reviews, interesting sightings, and a section called Field Notes. In the Field Notes section there are comments about bird species that have been sighted by members of the club. FADs were located by searching through the spring section of the $1933-2008$ Redstart's Field Notes. These observations include the common name, date of first spring sighting, and sometimes county. The majority of the data used in this study were first collected by members of the Brooks Bird Club. The club was founded by a group of young birders, including John Handlan, whose personal records of FADs in Ohio County were transcribed for the years 1929 and 1931, the years leading up to the creation of The Redstart. These records are in the possession of the Brooks Bird Club. 
George Breiding was a naturalist who lived in Wheeling, West Virginia and worked as a professor at West Virginia University from 1963 - 1979. He was an avid birder and took extensive notes on his observations. He also played an active role in the Brooks Bird Club, therefore, data gathered from his journals that were repeated in the data collected from the Brooks Bird Club were disregarded. His observations supplemented the data collected from 1955 -2006 .

Current spring arrival dates were obtained from the online birding checklist program, eBird (Sullivan et al., 2009). This program was launched in 2002 by the National Audubon Society and the Cornell Lab of Ornithology. The "First of the Year" spreadsheet, which is available online, documents the first date of observation recorded on the website for West Virginia. This is comparable to the spring arrival dates recorded by The Redstart, where members of the Brooks Bird Club would pool their observations and the editor would produce a list of the earliest sightings. FADs were recorded for the years $2003-2015$.

Species were categorized by population status (increasing, decreasing or steady), distance migrated (short- or long-distance), and foraging habitat (aerial, grassland, scrub, forest, or wetland) (Tables 2, 3, and 4). Population status of each species was determined using data from the Breeding Bird Survey (1966 - 2011) (Sauer et al., 2013). A short-distance migrant was defined by a southern maximum of migration being the southern US, Mexico or the Caribbean, and a long-distance migrant was defined by migration farther south than the Caribbean. One of five habitat categories were assigned to each species based on its primary feeding habitat (Butler, 2003).

Statistical analyses 
Species with at least 4 years of historical arrival dates (before 1970) and at least 5 years of arrival dates after 1970 were included in the analyses, which included 6,527 observations covering 52 of West Virginia's 55 counties. The majority (31.5\%) of the observations took place in $1929-1949,25 \%$ in $1990-2015,21.9 \%$ in $1950-1969,10.7 \%$ in $1970-1989$, and $10.2 \%$ in 1889 - 1928. Using these data, three general calculations were performed: the change in FAD for each species, average change over time across all species, and the difference between average historical and current FADs for each species. All analyses were performed in program R Version 3.2.1 (R Core Team, 2013) with package: Car (Fox \& Weisberg, 2011) at alpha level 0.05, unless specified.

First, the Julian dates of the FAD for each species were regressed against year using a generalized linear model to assess changes in spring arrival for each species over time. Overall normality was confirmed using the Shapiro-Wilk test $(\mathrm{W}=0.99, \mathrm{P}=0.82)$, and equal variances were confirmed using Levene's test $(\mathrm{F}=2.61, \mathrm{P}=0.34)$. Bonferroni corrections were made to the alpha value based on number of species in each Order (Table 5) in order to counteract the increased chance of incorrectly rejecting a null hypothesis that comes with multiple comparisons. Second, the slopes for all species were averaged to determine the average change in spring arrival. Lastly, average historical and current FADs for each species were calculated. Historical FADs were considered observations before 1970, and current FADs were calculated from the years 1970 or after. Both the historical (Shapiro-Wilk test, $\mathrm{W}=0.92, \mathrm{P}<0.01$ ) and current (Shapiro-Wilk test, $\mathrm{W}=0.95, \mathrm{P}<0.01$ ) dates were non-normal with non-equal variances (Kolmogorov-Smirnov test, $\mathrm{D}=0.23, \mathrm{P}<0.01$ ) despite transformations; therefore, the Wilcoxon signed-rank test was performed to assess the difference between historical and current arrival dates. The Wilcoxon signed-rank test is a nonparametric version of the matched-pairs t-test that 
is robust to non-normality and unequal variances as long as the data distributions of the samples are similar (Kerby, 2014), which makes it suitable for these data.

A 3-way Analysis of Variance test (ANOVA) was used to determine differences among changes in spring arrival based on population status (increasing, decreasing or steady), distance migrated (short- or long-distance), and foraging habitat (aerial, grassland, scrub, forest, or wetland) (Tables 2, 3, and 4). A Shapiro-Wilks test was used to confirm a normal distribution (W $=0.98, \mathrm{P}=0.15)$, and a Kolmogorov-Smirnov test was used to confirm equal variances $(\mathrm{D}=$ $0.12, \mathrm{P}=0.052)$

The average March - April temperature (C) for each year was calculated using data from the US Historical Climatology Network (Williams et al., 2007) and regressed against average FAD for each year using a generalized linear model. Normality was confirmed using a ShapiroWilk test $(\mathrm{W}=0.99, \mathrm{P}=0.44)$ and equal variances was confirmed using a Kolmogorov-Smirnov test $(\mathrm{D}=0.25, \mathrm{P}=0.08)$. Average county elevation $(\mathrm{m})$ was included for observations that included county information, and elevation was regressed against arrival date using a generalized linear model. This included $72.6 \%$ of the total observations $(n=4,743)$. Normality was confirmed using a Shapiro-Wilk test $(\mathrm{W}=0.99, \mathrm{P}=0.73)$; however a Kolmogorov-Smirnov test revealed non-equal variances $(\mathrm{D}=0.35, \mathrm{P}<0.01)$; however, a variety of transformations including $\log$ and square-root did not improve results.

\section{Results}

Of the 115 taxa, 45 species showed significant negative slopes of spring arrival dates (arriving earlier in the spring) plotted against year (Table 3), whereas only 9 species showed positive albeit non-significant slopes (arriving later in the spring) (Table 4). The other 61 species showed negative, non-significant slopes (Table 5). The mean slope of arrival date against year is 
-0.17 , which is equivalent to an average change $( \pm \mathrm{SD})$ in migration of $1.7 \pm 1.6$ days earlier every decade (Figure 2). Current arrival dates were significantly earlier than historical arrival dates $(\mathrm{W}=8479, \mathrm{p}<0.01)$ and the average difference between historical and current arrival dates was 8.2 days across species. Passeriformes was the most represented order $(n=5,117)$ including 83 species.

Overall, there was a significant difference in change of arrival among species based on life history traits $\left(\mathrm{F}_{22,92}=1.998, \mathrm{P}=0.012\right)$, specifically based on population status $\left(\mathrm{F}_{2,92}=\right.$ 4.725, $\mathrm{P}=0.011)$ and distance migrated $\left(\mathrm{F}_{1,92}=4.036, \mathrm{P}=0.047\right)$. The results of Tukey's posthoc test showed that species with increasing populations $(\bar{x}=-2.65$ days/decade, $S E=0.167)$ are advancing their spring migration significantly more than species with declining populations $(\bar{x}=$ -1.40 days/decade, $\mathrm{SE}=0.018)$, and short-distance migrants $(\bar{x}=-2.06$ days $/$ decade, $\mathrm{SE}=0.026)$ are advancing more than long-distance migrants $(\bar{x}=-1.40$ days/decade, $\mathrm{SE}=0.014)$. Therefore, it is not surprising that short-distance migrants with increasing populations $(\bar{x}=-2.97$ days/decade, $\mathrm{SE}=0.156)$ are advancing their FADs significantly more than long-distance migrants with declining populations $(\bar{x}=-1.29$ days/decade, $\mathrm{SE}=0.074)$. There was also a significant interaction between distance migrated and foraging habitat $\left(\mathrm{F}_{4,92}=2.504, \mathrm{P}=0.046\right)$. Long-distance migrants that forage in forests $(\bar{x}=-1.16$ days/decade, $\mathrm{SE}=0.074)$ are not advancing their FADs as much as aerial foragers that migrated short-distances $(\bar{x}=-5.11$ days/decade, $\mathrm{SE}=0.210$ ).

Between 1970 and 2014, average spring temperatures (March - April) in West Virginia increased 10 times as much as they did from $1880-1970$ (Figure 3). For every $1{ }^{\circ} \mathrm{C}$ increase of average spring temperature in West Virginia for the years between 1892 and 2014, the first average arrival date advanced by 0.81 days $\left(\mathrm{F}_{1,6114}=28.7, \mathrm{P}<0.001, \mathrm{~N}=6,115\right)$. The average 
spring temperature in West Virginia over the last century ranged from $5.4{ }^{\circ} \mathrm{C}(1960)$ to $11.6{ }^{\circ} \mathrm{C}$ (2012) (Figure 3). Average county elevation did have an effect on $F A D,\left(F_{1,4743}=3.88, P=0.049\right.$, $\mathrm{N}=4743$ ). For each $1000 \mathrm{~m}$ increase in elevation, FAD advanced by 4.0 days; however, given the range of observed observations $(\bar{x}=381 \mathrm{~m}, \mathrm{SE}=127.7 \mathrm{~m})$, this result is minor.

\section{Discussion}

The startling shift to earlier spring migration has strong implications for the future of these 45 species. With the threats of climate change and habitat destruction (Root et al., 2003, Jetz et al., 2007), it is a concern that anthropogenic factors are changing global habitats too quickly for species to respond and acclimate (Parmesan \& Yohe, 2003; Crick, 2004). This research, however, demonstrates the plasticity of responses of some avian species and highlights several factors that could lead to increased risk to other species due to climate change. The average migrating bird species is arriving in West Virginia 1.7 days earlier each decade. Of the 115 species, 45 showed a significant trend towards earlier spring arrival and zero showed a significant trend towards arriving later. West Virginia migrants from 12 orders indicated earlier spring arrival, demonstrating a substantial pattern in spring migration.

Avian migrants ideally arrive at their breeding grounds early enough to compete for superior territory, but not so early that foraging resources are unavailable. Individuals arriving too early experience harsh fitness consequences; however, arriving after competitors could decrease reproductive success. Given that spring plant phenologies, such as leaf-out, are advancing (Marra et al., 2005; Ellwood et al., 2010; Kelly et al., 2016) and the growing season has extended (Butler, 2003), the window of suitable spring arrival should advance as well. Therefore, individuals that may have arrived too early historically, may be rewarded in recent years. Several life history traits were associated with species that advanced their spring arrival, 
but we also acknowledge the importance of species-specific responses to changes in climate (McDermott \& DeGroote, 2016).

Short-distance migrants are advancing their FAD more than long-distance migrants, which supports our predictions and the idea that short-distance migrants are more affected by local weather conditions and can better respond to changing local climates by advancing their arrival. This advantage allows short-distance migrants to make decisions on the timing of migration based on local weather conditions that more closely match the conditions at the breeding grounds. The increased plasticity of short-distance migrants has been well-documented (Butler, 2003; Miller-Rushing et al., 2008; Ellwood et al., 2010; Gill et al., 2014). When comparing migration between long-distance and short-distance migrants, it is important to consider the cues associated with spring migration. Long-distance migrants depend on endogenous circannual rhythms to cue the beginning of their spring journey (Hagan et al., 1991), and short-distance migrants are more prone to use environmental cues (Miller-Rushing et al., 2008). The length of stopover can also vary with local habitat quality and food abundance (Marra et al., 2005), which contributes to the plasticity of arrival date. Long-distance migrants do have the ability to adjust their timing of arrival by adjusting their rate of migration to maximize resource availability based on ambient temperatures (Marra et al., 2005); however, since longdistance migrants are not advancing their spring migration at the same rate as short-distance migrants, long-distance migrants may be of increased conservation concern.

In line with our predictions, species with declining populations are not advancing their spring arrival dates as much as species with increasing populations. This may be due either to thriving populations having a greater plasticity in their responses, or to underestimated arrival dates in declining populations. FADs are especially susceptible to bias due to the prevalence of 
decreasing populations (Miller-Rushing et al., 2008); however, the bias leads toward mistakenly observing later arrival dates due to less individuals in a population that are available for detection. Therefore, any bias in the data due to population declines can be attributed to a conservative interpretation of the results.

Habitat alone was not a significant factor when analyzing FADs. These results are consistent with Miller-Rushing et al. (2010), but contrast with Butler (2003), who found that grassland species were not advancing their arrival as much as others. There was an interaction between foraging habitat and distance migrated that highlighted a disproportionate advancement of FADs between long-distance migrants that forage in forested habitats and short-distance migrants that are aerial foragers. Aerial foragers could be advancing their spring arrival more than other foragers due to their dependence on insects, given that insects are highly responsive to local changes in climate (Robinet \& Roques, 2010); however, species occupying forested habitats are also likely to be insectivores. Perhaps the prey insects of aerial foragers emerge sooner than insects in forested areas, which would drive the aerial foragers to arrive earlier, or it may be due to observer bias, given that aerial species could be seen more easily and therefore earlier. Since there was not an overall difference in FADs between aerial foragers and other species occupying different habitat types, the significant difference is only noticeable in shortdistance migrants that also have the benefit of increased plasticity to environmental change. The long-distance migrants that forage in forested habitats are advancing their FADs less than the overall average and less than the average long-distance migrant.

The arrival dates were significantly related to decadal spring temperatures, which supports the conclusions of similar studies (Swanson \& Palmer, 2009; Ellwood et al., 2010). Advancing spring temperatures has been linked to advancing plant phenologies (Wang et al., 
2015; Monahan et al., 2016), which would make the resource availability window for habitat and foraging earlier in the spring. This scenario would reward earlier-arriving individuals and successfully explains the trend of earlier arrival for most avian migrants (especially shortdistance migrants with increasing populations). Elevation had a surprising effect on FAD; as elevation increased, the FAD became earlier, which did not support our prediction; however, given the range of observed observations $(\bar{x}=381 \mathrm{~m}, \mathrm{SE}=127.7 \mathrm{~m})$, this result could be the consequence of a number of issues, including low number of observations at high elevations, most observations with specific locations (and therefore, elevations) were in the years before 1970, which would bias the data towards later FADs, or a combination of both. The state of West Virginia is highly variable geographically, so we argue that more exact location information is needed - using the average county elevation for observations does not capture enough of the variability in each county to make definite conclusions about the effect of elevation on spring arrival.

Several biases from the data sources have been considered in the results. It has been shown that increased observers result in seemingly earlier arrival dates (Courter et al., 2013; Arab et al., 2016). However, an argument for the integrity of the sources in this study can be made. All observers were experienced naturalists who visited a variety of habitats to observe migrating species. Earl Brooks' notes were gathered by himself and several of his colleagues, the Brooks Bird Club and eBird notes were compilations of observations from multiple observers, and the majority of George Brieding's lists were first of the year sightings for where he worked in Oglebay Park, Wheeling, WV, which were compiled by the staff and visitors to the park. The observer skill, time taken each week for birding, and distance covered during observations are 
still relatively unknown; however, similar datasets have been analyzed together with reputable results (Ellwood et al., 2010; Travers et al., 2015).

Given that most avian migrants are advancing their spring arrival and in some cases postponing autumn migration (Miles et al., 2016), a surge in the prevalence of individuals overwintering in the breeding grounds is increasingly possible (Kullberg et al., 2015; Newson et al., 2016), especially in short-distance migrants and species with increasing populations. In this study, species such as the Eastern Bluebird Sialia sialis, Brown Creeper Certhia americana, Eastern Towhee Pipilo erythrophthalmus, Common Grackle Quiscalus quiscula, White-throated Sparrow Zonotrichia albicollis, and White-crowned Sparrow Zonotrichia leucophrys were not analyzed because only historic records of first arrival were found. These species can now be found in West Virginia year round, possibly due to increased temperatures, urbanization, or increased presence of household feeders (Miller-Rushing, 2008). Further research on the potential of shifting wintering ranges would be important for future management of avian migrants.

In conclusion, the species that are at an increased risk of phenological decouplings and reduced success due to unchanging spring arrival include long-distance migrants and species with decreasing populations, especially those species that fall into both categories, such as the Cerulean Warbler Setophaga cerulea and Rose-breasted Grosbeak Pheucticus ludovicianus. Species with these two characteristics were considerably more likely to not have advanced their spring arrival. Responsiveness to changes in climate could predict a species' ability to survive in a global climate change scenario. 


\section{Acknowledgements}

We thank the many people who contributed observations and access to data, including the Brooks Bird Club, Mike Breiding, the West Virginia Regional History Center, and eBird. We also thank Thomas Rodd and Greg Good for ideas and logistics. Funding and logistical support was provided by the United States Department of Agriculture, Northeast Climate Hub, the West Virginia Humanities Council, and the West Virginia University Natural History Museum. We have no conflicts of interest to declare in relation to this manuscript. This is manuscript number xxxx of the West Virginia University Agriculture and Forestry Experiment Station.

\section{Literature Cited}

Arab A, Courter JR, Zelt J (2016) A spatio-temporal comparison of avian migration phenology using Citizen Science data. Spatial Statistics, 18, 234-245.

Ahola M, Laaksonen T, Sippola K, Eeva T, Rainio K, Lehikoinen E (2004) Variation in climate warming along the migration route uncouples arrival and breeding dates. Global Change Biology, 10, 1610-1617.

Bitterlin LR, Van Buskirk J (2014). Ecological and life history correlates of changes in avian migration timing in response to climate change. Climate Research, 61, 109-121.

Both C, Bouwhuis S, Lessells CM, Visser, ME (2006) Climate change and population declines in a long-distance migratory bird. Nature, 441, 81-83.

Both C, Visser ME (2001) Adjustment to climate change is constrained by arrival date in a longdistance migrant bird. Nature, 411, 296-298.

Bradley NL, Leopold AC, Ross J, Huffaker W (1999) Phenological changes reflect climate change in Wisconsin. Proceedings of the National Academy of Sciences, 96, 9701-9704.

Brooks EA (1915) Forty Common Birds of West Virginia. In: Arbor and Bird Day Manual (eds Brooks EA, Abbey MJ, Shawkey MP), pp. 21-79, Department of Free Schools, Charleston, West Virginia, USA. 
Butler CJ (2003) The disproportionate effect of global warming on the arrival dates of shortdistance migratory birds in North America. Ibis, 145, 484-495.

Cotton PA (2003) Avian migration phenology and global climate change. Proceedings of the National Academy of Sciences, 100, 12219-12222.

Courter JR, Johnson RJ, Stuyck CM, Lang BA, Kaiser EW (2013) Weekend bias in Citizen Science data reporting: implications for phenology studies. International Journal of Biometeorology, 57, 715-720.

Crick HQ (2004) The impact of climate change on birds. Ibis, 146, 48-56.

Ellwood ER, Primack RB, Talmadge ML (2010) Effects of climate change on spring arrival times of birds in Thoreau's Concord from 1851 to 2007. The Condor 112, 754-762.

Fox J, Weisberg S (2011) An \{R\} Companion to Applied Regression, Second Edition. Thousand Oaks CA: Sage. URL: http://socserv.socsci.mcmaster.ca/jfox/Books/Companion.

Gill JA, Alves JA, Sutherland WJ, Appleton GF, Potts PM, Gunnarsson TG (2014) Why is timing of bird migration advancing when individuals are not? Proceedings of the Royal Society of London B: Biological Sciences, 281, 20132161.

Gilroy JJ, Gill JA, Butchart SH, Jones VR, Franco A (2016) Migratory diversity predicts population declines in birds. Ecology Letters, 19, 308-317.

Gwinner E (1996) Circannual clocks in avian reproduction and migration. Ibis, 138, 47-63.

Hagan JM, Lloyd-Evans TL, Atwood JL (1991) The relationship between latitude and the timing of spring migration of North American landbirds. Ornis Scandinavica, 22, 129-136.

IPCC (2014) Climate change 2014: synthesis report. Contributions of Working Groups I, II, and III to the Fourth Assessment Report of the Intergovernmental Panel on Climate Change. IPCC, Geneva, Switzerland.

Jetz W, Wilcove DS, Dobson AP (2007) Projected impacts of climate and land-use change on the global diversity of birds. PLoS Biol, 5, e157. 
Jonzén N et al. (2006). Rapid advance of spring arrival dates in long-distance migratory birds. Science, 312, 1959-1961.

Kelly JF, Horton KG, Stepanian P M, Beurs KM, Fagin T, Bridge ES, Chilson PB (2016) Novel measures of continental-scale avian migration phenology related to proximate environmental cues. Ecosphere, 7, e01434.

Kerby DS (2014) The simple difference formula: An approach to teaching nonparametric correlation. Comprehensive Psychology, 3, 11-IT

Kerby JT, Post E (2013) Advancing plant phenology and reduced herbivore production in a terrestrial system associated with sea ice decline. Nature Communications, 4, 2514.

Kullberg C, Fransson T, Hedlund J, Jonzén N, Langvall O, Nilsson J, Bolmgren K (2015) Change in spring arrival of migratory birds under an era of climate change, Swedish data from the last 140 years. Ambio, 44, 69-77.

La Sorte FA, Hochachka WM, Farnsworth A, Dhondt AA, Sheldon D (2016) The implications of mid-latitude climate extremes for North American migratory bird populations. Ecosphere, 7, e01261.

Langham GM, Schuetz JG, Distler T, Soykan CU, Wilsey C (2015) Conservation status of North American birds in the face of future climate change. PloS One, 10, e0135350.

Lloyd-Evans TL, Atwood JL (2004) 32 years of changes in passerine numbers during spring and fall migrations in coastal Massachusetts. The Wilson Bulletin, 116, 1-16.

Marra PP, Francis CM, Mulvihill RS, Moore FR (2005) The influence of climate on the timing and rate of spring bird migration. Oecologia, 142, 307-315.

McDermott ME, DeGroote LW (2016) Long-term climate impacts on breeding bird phenology in Pennsylvania, USA. Global Change Biology, 22, 3304-3319.

McKinney AM, CaraDonna PJ, Inouye DW, Barr B, Bertelsen CD, Waser NM (2012) Asynchronous changes in phenology of migrating Broad-tailed Hummingbirds and their early-season nectar resources. Ecology, 93, 1987-1993. 
Miles WT et al. (2016) Quantifying full phenological event distributions reveals simultaneous advances, temporal stability and delays in spring and autumn migration timing in longdistance migratory birds. Global Change Biology, 23, 1400-1414.

Miller-Rushing AJ, Lloyd-Evans TL, Primack RB, Satzinger P (2008) Bird migration times, climate change, and changing population sizes. Global Change Biology, 14, 1959-1972.

Miller-Rushing AJ, Høye TT, Inouye DW, Post E (2010) The effects of phenological mismatches on demography. Philosophical Transactions of the Royal Society of London B: Biological Sciences. 365, 3177-3186.

Mills AM (2005) Changes in the timing of spring and autumn migration in North American migrant passerines during a period of global warming. Ibis, 147, 259-269.

Møller AP, Rubolini D, Lehikoinen E (2008) Populations of migratory bird species that did not show a phenological response to climate change are declining. Proceedings of the National Academy of Sciences, 105, 16195-16200.

Monahan WB, Rosemartin A, Gerst KL, Fisichelli NA, Ault T, Schwartz MD, Weltzin, JF (2016) Climate change is advancing spring onset across the US national park system. Ecosphere, 7, e01465.

Morin RS et al. (2016) West Virginia Forests 2013. Resource Bulletin NRS-105. Newtown Square, PA: U.S. Department of Agriculture, Forest Service, Northern Research Station. 128.

Newson SE, Moran NJ, Musgrove AJ, Pearce-Higgins JW, Gillings S, Atkinson PW, Baillie SR (2016) Long-term changes in the migration phenology of UK breeding birds detected by large-scale citizen science recording schemes. Ibis, 158, 481-495.

Parmesan C, Yohe G (2003) A globally coherent fingerprint of climate change impacts across natural systems. Nature, 421, 37-42.

R Core Team (2013) R: A language and environment for statistical computing. R Foundation for Statistical Computing, Vienna, Austria. URL: http://www.R-project.org/. 
Robbins CS, Sauer JR, Greenberg RS, Droege S (1989) Population declines in North American birds that migrate to the Neotropics. Proceedings of the National Academy of Sciences. 86, 7658-7662.

Robinet C, Roques A (2010) Direct impacts of recent climate warming on insect populations. Integrative Zoology, 5, 132-142.

Root TL, Price JT, Hall KR, Schneider SH, Rosenzweig C, Pounds JA (2003) Fingerprints of global warming on wild animals and plants. Nature, 421, 57-60.

Sauer JR, Link WA, Fallon JE, Pardieck KL, Ziolkowski Jr DJ (2013) The North American breeding bird survey 1966-2011: summary analysis and species accounts. North American Fauna, 79, 1-32.

Shaw DW, Escalante P, Rappole JH, Ramos MA, Oehlenschlager RJ, Warner DW, Winker K (2013) Decadal changes and delayed avian species losses due to deforestation in the northern Neotropics. PeerJ, 1, e179.

Studds CE, Marra PP (2011) Rainfall-induced changes in food availability modify the spring departure programme of a migratory bird. Proceedings of the Royal Society of London B: Biological Sciences, 10, e1089.

Sullivan BL, Wood CL, Iliff MJ, Bonney RE, Fink D, Kelling S (2009) eBird: A citizen-based bird observation network in the biological sciences. Biological Conservation, 142, 22822292.

Swanson DL, Palmer JS (2009) Spring migration phenology of birds in the Northern Prairie region is correlated with local climate change. Journal of Field Ornithology, 80, 351-363.

Travers SE, Marquardt B, Zerr NJ, Finch JB, Boche MJ, Wilk R, Burdick SC (2015) Climate change and shifting arrival date of migratory birds over a century in the northern Great Plains. The Wilson Journal of Ornithology, 127, 43-51.

Tryjanowski PSTH, Sparks TH (2001) Is the detection of the first arrival date of migrating birds influenced by population size? A case study of the red-backed shrike Lanius collurio. International Journal of Biometeorology, 45, 217-219. 
Vegvari Z, Bokony V, Barta Z, Kovacs G (2010) Life history predicts advancement of avian spring migration in response to climate change. Global Change Biology, 16, 1-11.

Visser ME, Both C (2005) Shifts in phenology due to global climate change: the need for a yardstick. Proceedings of the Royal Society of London B: Biological Sciences, 272, $2561-2569$.

Visser ME, Holleman LJ, Gienapp P (2006) Shifts in caterpillar biomass phenology due to climate change and its impact on the breeding biology of an insectivorous bird. Oecologia, 147, 164-172.

Wang X, Piao S, Xu X, Ciais P, MacBean N, Myneni RB, Li L (2015) Has the advancing onset of spring vegetation green-up slowed down or changed abruptly over the last three decades? Global Ecology and Biogeography, 24, 621-631.

Williams Jr CN, Menne MJ, Vose RS, Easterling DR (2007) United States historical climatology network monthly temperature and precipitation data. ORNL/CDIAC-118, NDP-019. Carbon Dioxide Information Analysis Center, Oak Ridge National Laboratory, US Department of Energy, Oak Ridge, Tennessee, USA.

Willis CG, Ruhfel B, Primack RB, Miller-Rushing AJ, Davis CC (2008) Phylogenetic patterns of species loss in Thoreau's woods are driven by climate change. Proceedings of the National Academy of Sciences, 105, 17029-17033. 
Tables and Figures:

Table 1 Sources used to find historical first arrival dates of migrating bird species [in West Virginia, USA from 1890 - 2015].

\begin{tabular}{|c|c|c|c|c|}
\hline Collector & Location of record & Type of record & Timeframe & $\begin{array}{c}\text { \# of } \\
\text { observations }\end{array}$ \\
\hline Earl Brooks & $\begin{array}{c}\text { West Virginia } \\
\text { Regional History } \\
\text { Center }\end{array}$ & $\begin{array}{l}\text { Handwritten } \\
\text { ornithological notes of } \\
\text { breeding and } \\
\text { migration }\end{array}$ & $1890-1916$ & 674 \\
\hline $\begin{array}{l}\text { Brooks Bird } \\
\text { Club }\end{array}$ & $\begin{array}{c}\text { West Virginia } \\
\text { Regional History } \\
\text { Center }\end{array}$ & $\begin{array}{l}\text { Printed spring bird } \\
\text { arrival dates from the } \\
\text { Redstart }\end{array}$ & $1929-2008$ & 4023 \\
\hline $\begin{array}{l}\text { George } \\
\text { Brieding }\end{array}$ & Personal Collection & $\begin{array}{l}\text { Handwritten and typed } \\
\text { lists of arrival dates }\end{array}$ & $1955-2006$ & 729 \\
\hline eBird & www.ebird.org & $\begin{array}{l}\text { Spreadsheet of first of } \\
\text { the year sightings }\end{array}$ & $2003-2015$ & 1101 \\
\hline Total & & & $1890-2015$ & 6527 \\
\hline
\end{tabular}




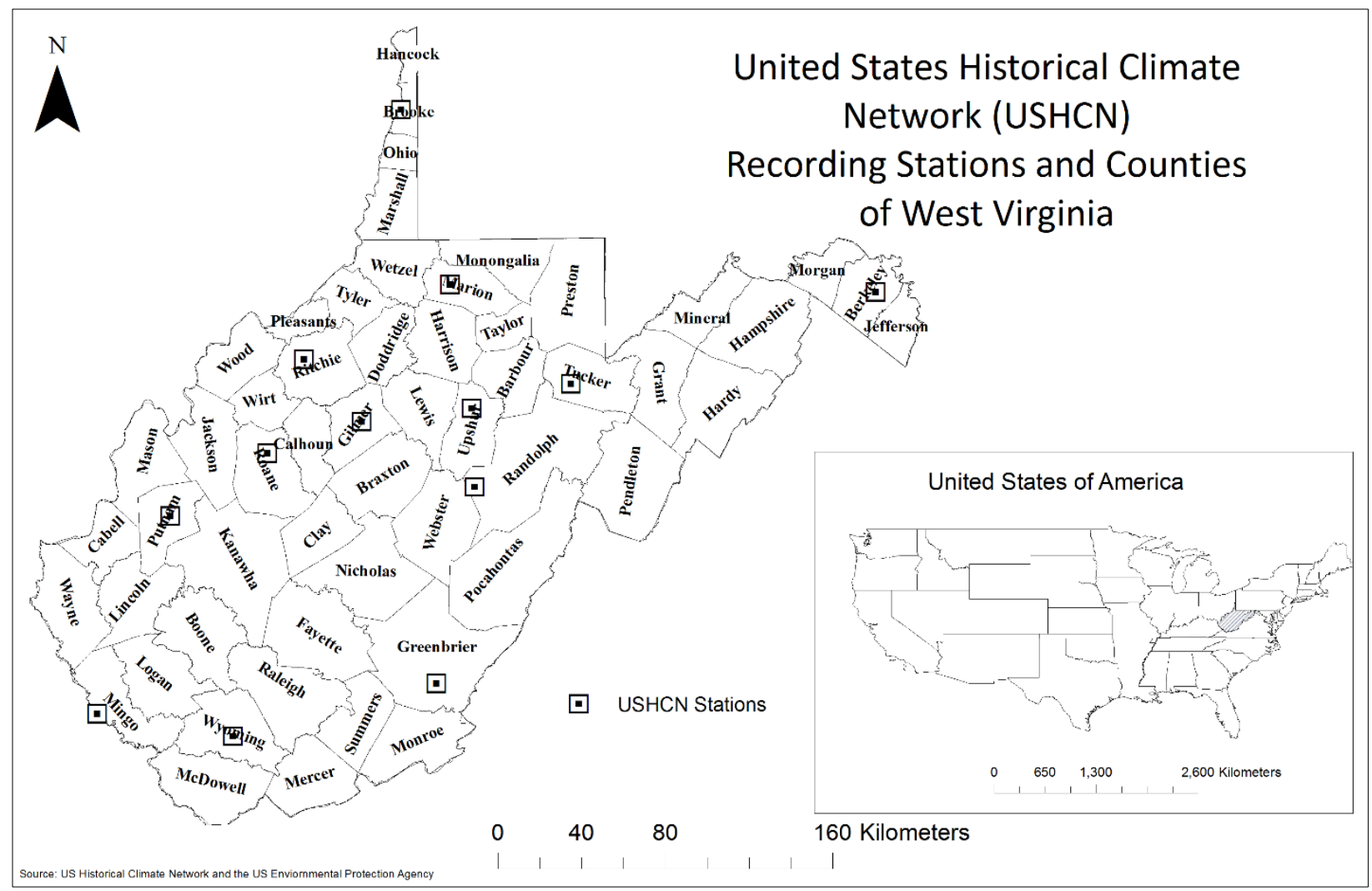

Fig. 1 Map of West Virginia counties and climate recording stations of the United States Historical Climate Network. 
Table 2 Species that demonstrated significant trends towards earlier first arrival dates (FADs) in West Virginia. USA. Foraging habitat is denoted by $\mathrm{f}$ (forest), w (wetland), a (aerial), $\mathrm{s}$ (scrub), and g (grassland). Population status is denoted by + (increasing), (decreasing), and = (steady). Distance is categorized either by short-distance migrants (wintering north of the Caribbean) or longdistance migrants (wintering south of the Caribbean). Historical FAD is the average arrival date before 1970 and current FAD is the average arrival date of 1970 or after.

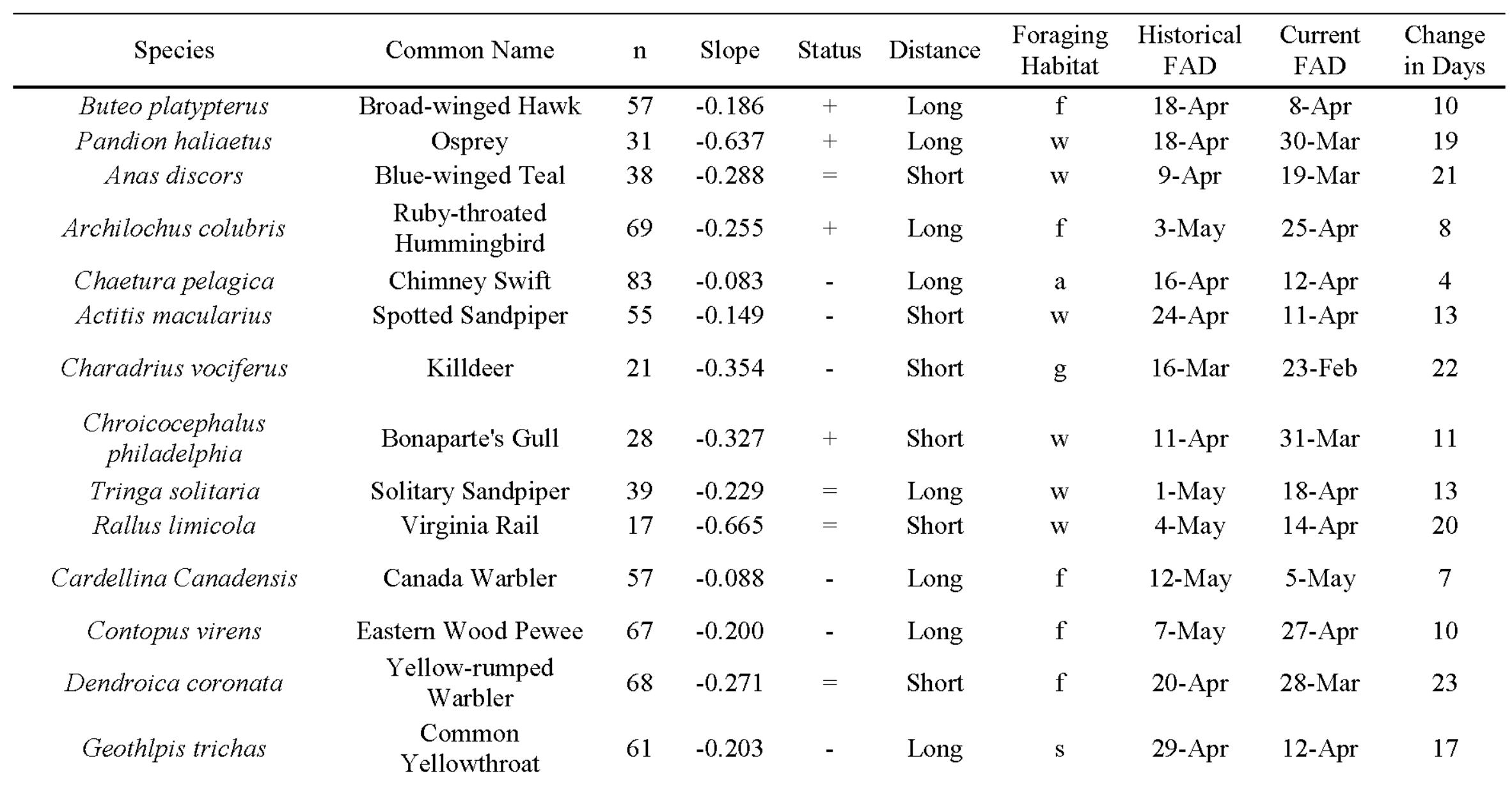




\begin{tabular}{|c|c|c|c|c|c|c|c|c|c|}
\hline Helmitheros vermivorus & Worm-eating Warbler & 74 & -0.095 & $=$ & Short & $\mathrm{f}$ & 29-Apr & 21-Apr & 8 \\
\hline Hirundo rustica & Barn Swallow & 90 & -0.209 & - & Long & a & 17-Apr & 6-Apr & 10 \\
\hline Icterus galbula & Baltimore Oriole & 87 & -0.086 & - & Long & $\mathrm{f}$ & 28-Apr & 18-Apr & 9 \\
\hline Leiothylpis ruficapilla & Nashville Warbler & 74 & -0.088 & $=$ & Long & $\mathrm{f}$ & 2-May & 24-Apr & 8 \\
\hline Mniotilta varia & $\begin{array}{c}\text { Black and White } \\
\text { Warbler }\end{array}$ & 95 & -0.133 & - & Long & $\mathrm{f}$ & 21-Apr & 11-Apr & 10 \\
\hline Passerculus sandwichensis & Savannah Sparrow & 54 & -0.538 & - & Short & $\mathrm{g}$ & 15-Apr & 26-Mar & 20 \\
\hline Passerina cyanea & Indigo Bunting & 71 & -0.124 & - & Long & $\mathrm{g}$ & 1-May & 26-Apr & 5 \\
\hline Petrochelidon pyrrhonota & Cliff Swallow & 37 & -0.230 & - & Long & $\mathrm{a}$ & 3-May & 13-Apr & 20 \\
\hline Pheucticus ludovicianus & $\begin{array}{l}\text { Rose-breasted } \\
\text { Grosbeak }\end{array}$ & 60 & -0.279 & - & Long & f & 5-May & 18-Apr & 17 \\
\hline Piranga olivacea & Scarlet Tanager & 83 & -0.184 & - & Long & $\mathrm{f}$ & 27-Apr & 18-Apr & 9 \\
\hline Polioptila caerulea & Blue-gray Gnatcatcher & 93 & -0.202 & + & Short & $\mathrm{f}$ & 16-Apr & 10-Apr & 6 \\
\hline Seiurus aurocapilla & Ovenbird & 84 & -0.121 & $=$ & Short & $\mathrm{f}$ & 30-Apr & 19-Apr & 11 \\
\hline Setophaga americana & $\begin{array}{c}\text { Northern Parula } \\
\text { Warbler }\end{array}$ & 81 & -0.173 & + & Long & $\mathrm{f}$ & 28-Apr & 16-Apr & 12 \\
\hline Setophaga cerulea & Cerulean Warbler & 77 & -0.117 & - & Long & $\mathrm{f}$ & 29-Apr & 22-Apr & 7 \\
\hline Setophaga citrina & Hooded Warbler & 84 & -0.145 & + & Short & $\mathrm{f}$ & 28-Apr & 19-Apr & 9 \\
\hline Setophaga dominica & $\begin{array}{c}\text { Yellow-throated } \\
\text { Warbler }\end{array}$ & 54 & -0.494 & + & Short & $\mathrm{f}$ & 24-Apr & 6-Apr & 18 \\
\hline Setophaga pensylvanica & $\begin{array}{l}\text { Chestnut-sided } \\
\text { Warbler }\end{array}$ & 80 & -0.103 & - & Long & $\mathrm{s}$ & 3-May & 26-Apr & 7 \\
\hline Setophaga pinus & Pine Warbler & 32 & -0.553 & + & Short & $\mathrm{f}$ & 16-Apr & 11-Mar & 36 \\
\hline Setophaga Ruticilla & American Redstart & 91 & -0.122 & $=$ & Long & $\mathrm{f}$ & 29-Apr & 22-Apr & 7 \\
\hline
\end{tabular}




\begin{tabular}{|c|c|c|c|c|c|c|c|c|c|}
\hline Setophaga virens & $\begin{array}{c}\text { Black-throated Green } \\
\text { Warbler }\end{array}$ & 92 & -0.216 & $=$ & Long & $\mathrm{f}$ & $25-\mathrm{Apr}$ & 4-Apr & 21 \\
\hline Stelgidopteryx serripennis & $\begin{array}{l}\text { Northern Rough- } \\
\text { winged Swallow }\end{array}$ & 62 & -0.362 & $=$ & Short & $\mathrm{a}$ & 16-Apr & 29-Mar & 18 \\
\hline Tachycineta bicolor & Tree Swallow & 49 & -0.660 & - & Short & $\mathrm{a}$ & 15-Apr & 11-Mar & 35 \\
\hline Toxostoma Rufum & Brown Thrasher & 83 & -0.187 & - & Short & $\mathrm{s}$ & 9-Apr & 31-Mar & 9 \\
\hline Tyrannus tyrannus & Eastern Kingbird & 72 & -0.283 & - & Long & $\mathrm{f}$ & 1-May & 16-Apr & 15 \\
\hline Vermivora cyanoptera & Blue-winged Warbler & 77 & -0.177 & $=$ & Long & $\mathrm{s}$ & 29-Apr & 21-Apr & 8 \\
\hline Vireo flavifrons & Yellow-throated Vireo & 89 & -0.148 & + & Short & $\mathrm{f}$ & 27-Apr & 17-Apr & 10 \\
\hline Vireo gilvus & Warbling Vireo & 87 & -0.078 & - & Long & $\mathrm{f}$ & 27-Apr & 21-Apr & 6 \\
\hline Vireo solitarius & Blue-headed Vireo & 61 & -0.380 & + & Short & $\mathrm{f}$ & 25-Apr & 31-Mar & 25 \\
\hline Ardea herodias & Great Blue Heron & 17 & -0.764 & $=$ & Short & $\mathrm{w}$ & 29-Mar & 4-Mar & 25 \\
\hline Butorides virescens & Green Heron & 62 & -0.169 & - & Short & $\mathrm{w}$ & 24-Apr & 14-Apr & 10 \\
\hline Podilymbus auritus & Horned Grebe & 21 & -0.532 & $=$ & Short & $\mathrm{w}$ & $1-A p r$ & 22-Mar & 10 \\
\hline
\end{tabular}


Table 3 Species that demonstrated non-significant, later trends in first arrival dates (FADs) in West Virginia, USA. Foraging habitat is denoted by f (forest), w (wetland), a (aerial), s (scrub), and g (grassland). Population status is denoted by + (increasing), - (decreasing), and $=($ steady). Distance is categorized either by short-distance migrants (wintering north of the Caribbean) or long-distance migrants (wintering south of the Caribbean). Historical FAD is the average arrival date before 1970 and current FAD is the average arrival date of 1970 or after.

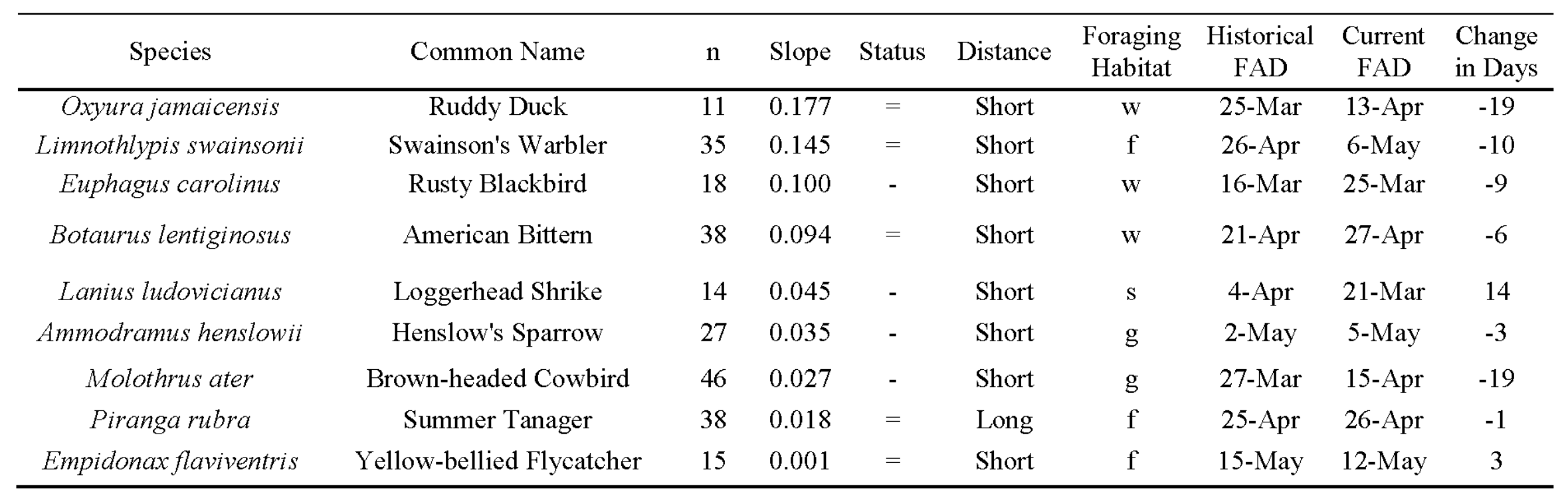


Table 4 Species that demonstrated non-significant, but earlier trends in first arrival dates (FADs) in West Virginia, USA. Foraging habitat is denoted by $\mathrm{f}$ (forest), w (wetland), a (aerial), $\mathrm{s}$ (scrub), and g (grassland). Population status is denoted by + (increasing), (decreasing), and = (steady). Distance is categorized either by short-distance migrants (wintering north of the Caribbean) or longdistance migrants (wintering south of the Caribbean). Historical FAD is the average arrival date before 1970 and current FAD is the average arrival date of 1970 or after. Species that are bold would be significant if no Bonferroni corrections were used.

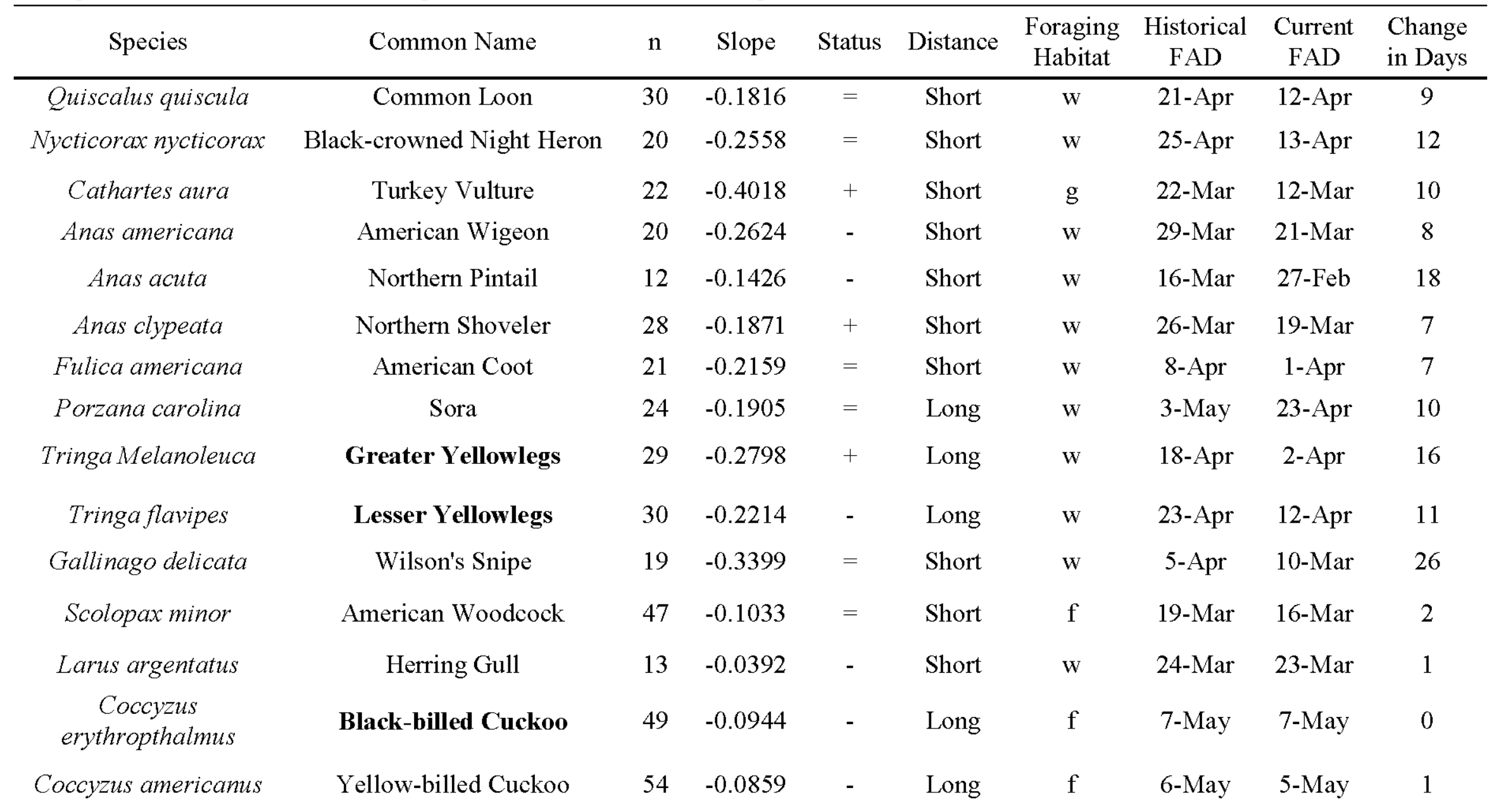




\begin{tabular}{|c|c|c|c|c|c|c|c|c|}
\hline Chordeiles minor & Common Nighthawk & 59 & -0.1793 & - & Long & $\mathrm{a}$ & 7-May & 27-Apr \\
\hline Caprimulgus vociferus & Whippoorwill & 66 & -0.1193 & - & Short & $\mathrm{f}$ & 18-Apr & 16-Apr \\
\hline Setophaga discolor & Prairie Warbler & 45 & -0.0486 & - & Short & $\mathrm{s}$ & 23-Apr & 23-Apr \\
\hline $\begin{array}{l}\text { Vermivora } \\
\text { chrysoptera }\end{array}$ & Golden-winged Warbler & 69 & -0.0179 & - & Long & $\mathrm{s}$ & 3-May & 3-May \\
\hline $\begin{array}{l}\text { Ammodramus } \\
\text { savannarum }\end{array}$ & Grasshopper Sparrow & 54 & -0.0126 & - & Short & $\mathrm{g}$ & 25-Apr & 27-Apr \\
\hline Sturnella magna & Eastern Meadowlark & 23 & -0.0177 & - & Short & $\mathrm{g}$ & 9-Mar & 8-Mar \\
\hline $\begin{array}{l}\text { Dendroica } \\
\text { caerulescens }\end{array}$ & $\begin{array}{c}\text { Black-throated Blue } \\
\text { Warbler }\end{array}$ & 68 & -0.0837 & + & Long & $\mathrm{f}$ & 4-May & 28-Apr \\
\hline Geothlpis formosa & Kentucky Warbler & 82 & -0.0693 & - & Long & $\mathrm{f}$ & 29-Apr & 26-Apr \\
\hline Icterus spurius & Orchard Oriole & 72 & -0.1237 & - & Long & $\mathrm{f}$ & 1-May & 23-Apr \\
\hline Setophaga striata & Blackpoll Warbler & 64 & -0.1007 & $=$ & Long & $\mathrm{f}$ & 12-May & 5-May \\
\hline Dolichonyx oryzivorus & Bobolink & 35 & -0.138 & - & Long & $\mathrm{g}$ & 5-May & 29-Apr \\
\hline Sayornis phoebe & Eastern Phoebe & 78 & -0.2744 & $=$ & Short & $\mathrm{s}$ & 22-Mar & 17-Mar \\
\hline Parkesia motacilla & Louisiana Waterthrush & 102 & -0.1108 & + & Long & f & 8-Apr & 30-Mar \\
\hline Leiothlypis peregrina & Tennessee Warbler & 77 & -0.0853 & $=$ & Long & $\mathrm{f}$ & 6-May & 2-May \\
\hline Setophaga petechia & Yellow Warbler & 102 & -0.0777 & - & Long & $\mathrm{f}$ & 20-Apr & 16-Apr \\
\hline Setophaga magnolia & Magnolia Warbler & 67 & -0.0769 & $=$ & Long & $\mathrm{f}$ & 7-May & 1-May \\
\hline Protonotaria citrea & Prothonotary Warbler & 33 & -0.2867 & - & Long & $\mathrm{f}$ & 4-May & 27-Apr \\
\hline Catharus guttatus & Hermit Thrush & 42 & -0.2176 & $=$ & Short & $\mathrm{f}$ & 17-Apr & 20-Mar \\
\hline
\end{tabular}




\begin{tabular}{|c|c|c|c|c|c|c|c|c|}
\hline Vireo griseus & White-eyed Vireo & 55 & -0.1277 & + & Short & $\mathrm{s}$ & 23-Apr & 19-Apr \\
\hline Spizella passerina & Chipping Sparrow & 60 & -0.2345 & - & Short & $\mathrm{s}$ & 30-Mar & 24-Mar \\
\hline Passerella iliaca & Fox Sparrow & 23 & -0.4797 & $=$ & Short & $\mathrm{f}$ & 3-Apr & 21-Mar \\
\hline Empidonax minimus & Least Flycatcher & 62 & -0.0939 & - & Short & $\mathrm{f}$ & 7-May & 2-May \\
\hline Progne subis & Purple Martin & 91 & -0.1018 & - & Long & a & 6-Apr & 2-Apr \\
\hline Empidonax virescens & Acadian Flycatcher & 58 & -0.1097 & - & Long & $\mathrm{f}$ & 5-May & 1-May \\
\hline Vireo olivaceus & Red-eyed Vireo & 98 & -0.0747 & + & Long & f & 28-Apr & 21-Apr \\
\hline Hylocichla mustelina & Wood Thrush & 106 & -0.0588 & - & Long & $\mathrm{f}$ & 21-Apr & 19-Apr \\
\hline Cardellina pusilla & Wilson's Warbler & 49 & -0.0907 & $=$ & Short & $\mathrm{f}$ & 13-May & 8-May \\
\hline Setophaga palmarum & Palm Warbler & 36 & -0.109 & $=$ & Short & $\mathrm{f}$ & 29-Apr & 22-Apr \\
\hline Melospiza lincolnii & Lincoln's Sparrow & 23 & -0.513 & - & Short & $\mathrm{s}$ & 8-May & 29-Apr \\
\hline Riparia riparia & Bank Swallow & 56 & -0.0989 & - & Long & $\mathrm{a}$ & 30-Apr & 19-Apr \\
\hline Troglodytes aedon & House Wren & 80 & -0.1039 & $=$ & Short & $\mathrm{s}$ & 17-Apr & 14-Apr \\
\hline $\begin{array}{c}\text { Geothlypis } \\
\text { philadelphia }\end{array}$ & Mourning Warbler & 28 & -0.0901 & - & Long & f & 12-May & 7-May \\
\hline Melospiza georgiana & Swamp Sparrow & 26 & -0.2629 & $=$ & Short & w & 7-Apr & 27-Mar \\
\hline Agelaius phoeniceus & Red-winged Blackbird & 36 & -0.2551 & - & Short & $\mathrm{w}$ & 18-Mar & 18-Mar \\
\hline Icteria virens & Yellow-breasted Chat & 85 & -0.0316 & - & Short & $\mathrm{s}$ & 1-May & 30-Apr \\
\hline Myiarchus crinitus & Crested Flycatcher & 68 & -0.0991 & $=$ & Short & $\mathrm{f}$ & 26-Apr & 25-Apr \\
\hline
\end{tabular}




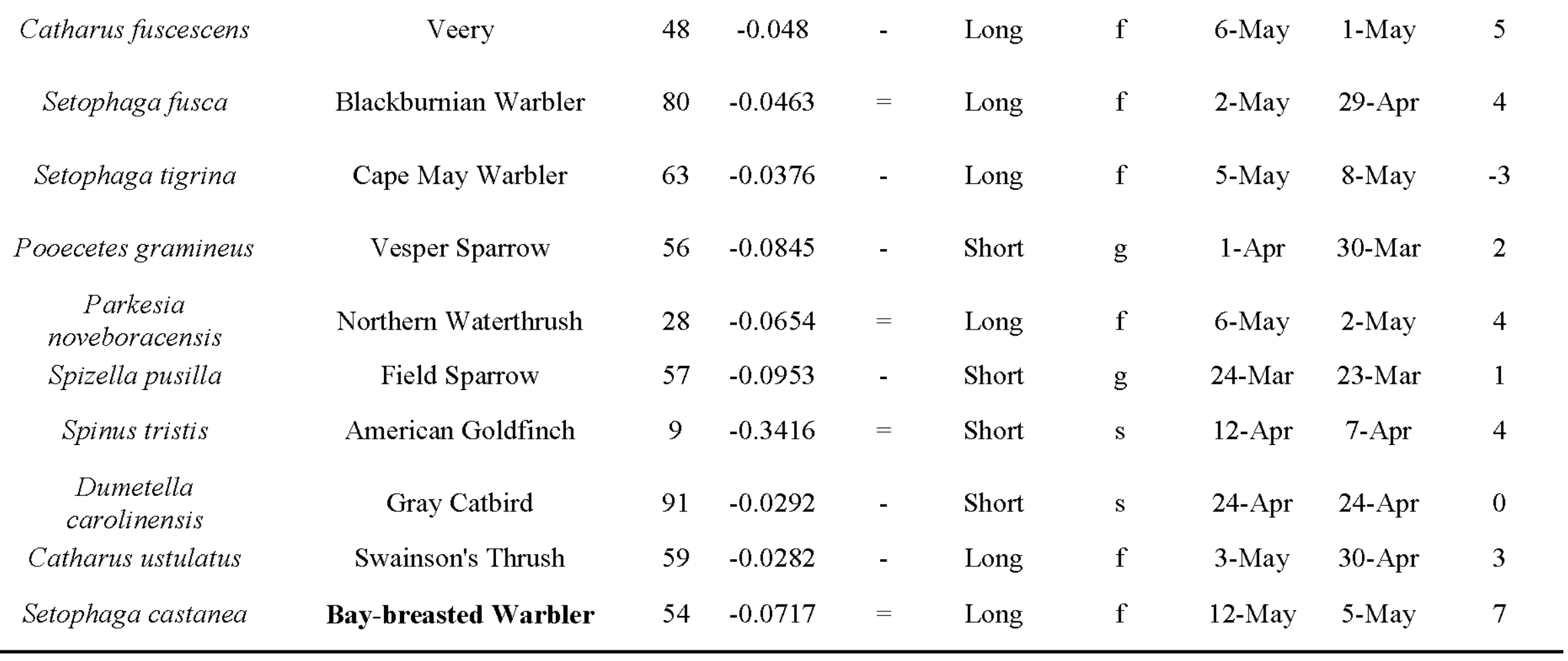


Table 5 Bonferroni corrections were made to the alpha values (0.05) based on number of species within an Order.

\begin{tabular}{cccc}
\hline Order & $\begin{array}{c}\text { Number of } \\
\text { Species }\end{array}$ & Alpha Value & $\begin{array}{c}\text { Significant } \\
\text { Species }\end{array}$ \\
\hline Gaviiformes & 1 & 0.0500 & 0 \\
Podicipediformes & 1 & 0.0500 & 1 \\
Pelecaniformes & 4 & 0.0125 & 2 \\
Cathartiformes & 1 & 0.0500 & 0 \\
Anseriformes & 5 & 0.0125 & 1 \\
Accipitriformes & 2 & 0.0250 & 2 \\
Gruiformes & 3 & 0.0167 & 1 \\
Charadriiformes & 9 & 0.0056 & 4 \\
Cuculiformes & 2 & 0.0250 & 0 \\
Caprimulgiformes & 2 & 0.0250 & 0 \\
Apodiformes & 2 & 0.0250 & 2 \\
Passeriformes & 83 & 0.0006 & 32 \\
\hline
\end{tabular}




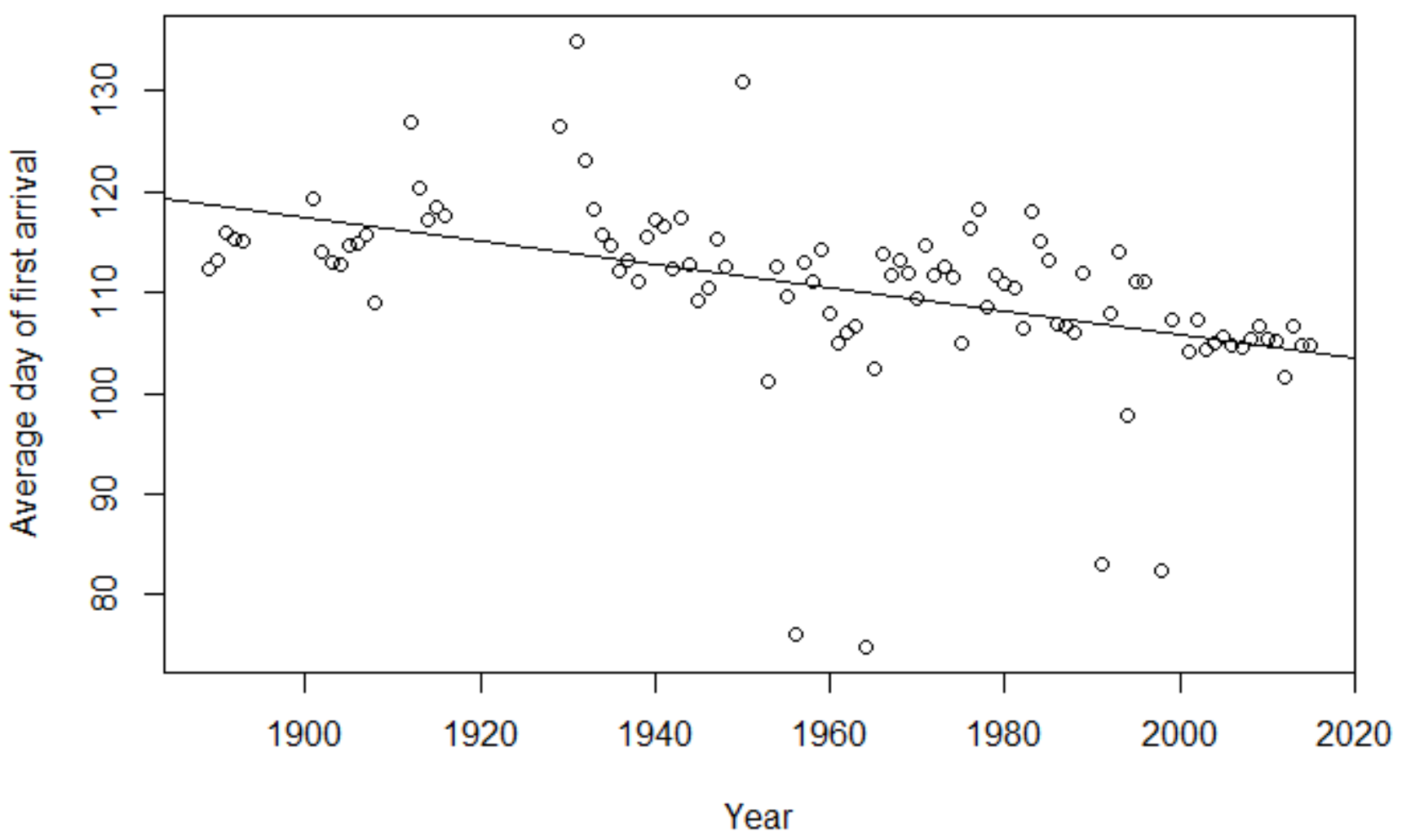

Fig. 2 The average yearly first arrival date across 115 species in West Virginia (1889 - 2015). 


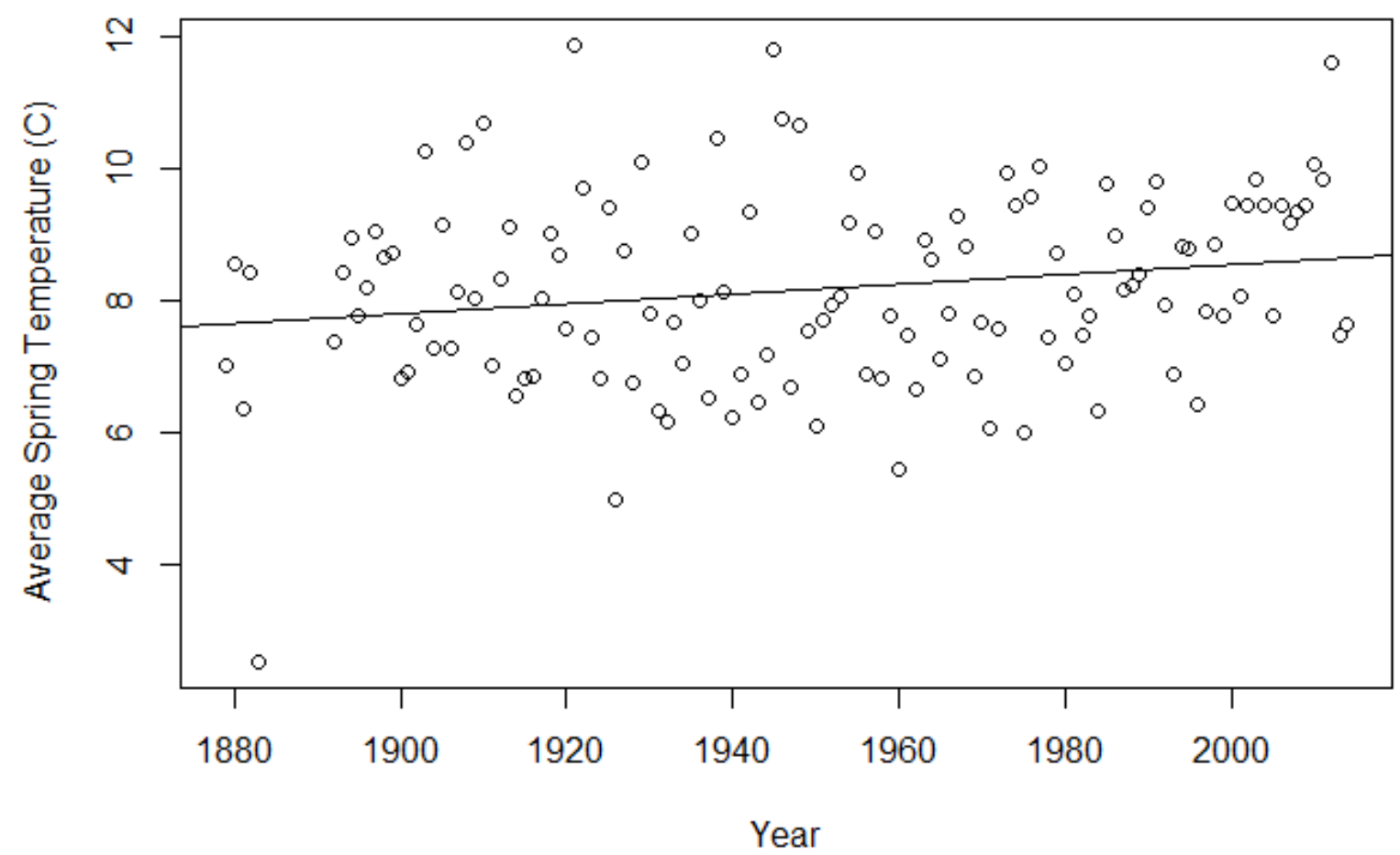

Fig 3 Mean March-April temperatures in West Virginia (1890 - 2014). Data recorded by the United States Historical Climate Network. 